AUTARQUIA ASSOCIADA À UNIVERSIDADE DE SÃO PAULO

\title{
AVALIAÇÃO MORFOLÓGICA E BIOMECÂNICA DE TECIDO TENDINOSO HUMANO ESTERILIZADO POR RADIAÇÃO IONIZANTE
}

ANA PAULA FUNARI

Dissertação apresentada como parte dos requisitos para obtenção do Grau de Mestre em Ciências na Área de Tecnologia Nuclear - Aplicações

Orientadora:

Profa. Dra. Monica Beatriz Mathor 
INSTITUTO DE PESQUISAS ENERGÉTICAS E NUCLEARES

Autarquia associada à Universidade de São Paulo

\section{AVALIAÇÃO MORFOLÓGICA E BIOMECÂNICA DE TECIDO TENDINOSO HUMANO ESTERILIZADO POR RADIAÇÃO IONIZANTE}

ANA PAULA FUNARI

Dissertação apresentada como parte dos requisitos para obtenção do Grau de Mestre em Ciências na Área de Tecnologia Nuclear - Aplicações

Orientadora:

Profa. Dra. Monica Beatriz Mathor

Versão Corrigida

Versão Original disponível no IPEN

São Paulo 
Dedico o presente trabalho aos meus pais Maria Elena Funari e Vanderli A. Funari pelos ensinamentos e apoio incondicional dados a mim, à minha irmã Thais $C$. Funari por sempre me apoiar e encorajar com palavras de estimulo, ao meu querido sobrinho Vicente por ser esta pessoinha maravilhosa, um raio de sol em nossas vidas. 


\section{AGRADECIMENTOS}

À minha orientadora Dra. Monica Beatriz Mathor pela oportunidade de aprender e adquirir conhecimento, pelos ensinamentos, pelo incentivo, pela ajuda no desenvolvimento do trabalho.

Ao Instituto de Pesquisas Energéticas e Nucleares IPEN/CNEN, pelo suporte para o desenvolvimento do trabalho de mestrado.

Ao Prof. Dr. Anderson Zanardi de Freitas pela contribuição na realização deste trabalho.

Ao Prof. Dr. Rafael Traldi Moura do Departamento de Mecatrônica e Sistemas Mecânicos da Escola Politécnica pela sua contribuição para realização deste trabalho, pelos ensinamentos, pelas conversas, pelo interesse no trabalho, e pela amizade.

Ao Prof. Dr. Daniel Perez Vieira pela sua contribuição na realização deste trabalho.

Ao Dr. Luiz Augusto Santos pela ajuda na aquisição das amostras para realização deste trabalho.

Ao Me. Jurandir Tomaz de Miranda pela ajuda com o processamento das imagens histológicas, por todo apoio dado a mim e pela sua amizade.

À Dra. Amanda Cristina Ramos Koike pela ajuda dada em minha jornada, pela parceria nos momentos bons e nos difíceis também, e pela contribuição na parte estrutural do trabalho, mas principalmente pela sua amizade.

À Dra. Daniele Seo Hieda pela ajuda nos momentos bons e nos difíceis, pela troca de conhecimentos e principalmente pela sua amizade. 
À Camila Almeida Amorim pela sua ajuda com o trabalho, pela sua amizade e pelos momentos únicos proporcionados por sua pessoa.

Ao Dr. Luis Alberto Dias meu muito obrigado pela sua ajuda no início da minha jornada muito obrigada por tudo, mas principalmente pela sua amizade.

Ao Prof. Dr. Leonardo Gondim de Andrade e Silva, pela oportunidade de participar do programa PAE, e pela sua amizade.

À Prof ${ }^{a}$ Dra. Luci D. B. Machado pelo apoio, pelas conversas e momentos de descontração e pela amizade.

À Prof ${ }^{\mathrm{a}}$ Dra.Solange Sakata pelo apoio, pelos momentos de descontração e pela amizade.

Aos amigos do CTR, Jaqueline J. Souza, Luiza Ferreira Juliana, Angélica Barbezan, Uri Antebi, Nelson Mendes, obrigada pela amizade, pelos momentos de descontração, pelo apoio dado a mim, pela inestimável ajuda, levo comigo um pouco de cada um de vocês.

Aos amigos da sala de mestrado Beatriz Nogueira, Diego Vergaças, Bruna Teiga, Carla de Souza, Alexandre Velo, obrigada pela amizade e pelos momentos que passamos juntos, levo comigo um pouco de cada um de vocês.

Aos profissionais do irradiador multipropósito do Centro de Tecnologia das Radiações (CTR), Paulo, Nunes e Edmilson, pela gentileza e auxilio no processamento das amostras.

Aos secretários Marcos Cardoso e Cláudia Regina Nolla do Centro de Tecnologia da Radiação - IPEN pelo auxílio dado a mim e pela amizade.

À Comissão Nacional de Energia Nuclear - CNEN pela bolsa de mestrado concedida. 
Ao Departamento de Ensino do IPEN, em especial a Ana Cláudia Martinelli, Bruna Roque, Bianca Gonçalves Montes, Ana Paula Morelli Bertoni, Andressa Santos e Ilze Puglia, meu muito obrigada pela amizade e presteza de todas vocês.

A todos que não foram citados, mas que de alguma forma colaboraram para realização deste trabalho. 


\title{
AVALIAÇÃO MORFOLÓGICA E BIOMECÂNICA DE TECIDO TENDINOSO HUMANO ESTERILIZADO POR RADIAÇÃO IONIZANTE
}

\author{
Ana Paula Funari
}

\section{RESUMO}

O crescente aumento do interesse no desenvolvimento em técnicas cirúrgicas menos invasivas, como nas reconstruções tendíneas e ligamentares, tem levado ao aumento das pesquisas referentes ao uso de aloenxertos esterilizados por radiação ionizante. $O$ processamento por radiação ionizante é um método seguro e não deixa resíduos, sendo utilizado como esterilização final. O presente estudo teve como proposta avaliar os efeitos da aplicação de radiação ionizante, produzida por fonte de ${ }^{60} \mathrm{Co}$, em amostras de tendões humanos pré processados de doadores multiorgãos obtidas por meio de colaboração com Bancos de Tecidos. O pré-processamento das amostras deu-se por métodos químicos e preservação por congelamento em $-80^{\circ} \mathrm{C}$. As doses aplicadas no processamento por radiação foram de 12,5 kGy, 15,0 kGy e 25,0 kGy, cada uma com seu respectivo controle não irradiado. As amostras foram avaliadas por meio de testes histológicos, ópticos e biomecânicos, com o objetivo de analisar possíveis modificações morfológicas e estruturais. Os resultados apresentados demonstraram que o processamento por ultrassom e peróxido de hidrogênio causaram alterações na morfologia dos tecidos, o que ocasionou danos à sua estrutura, inviabilizando as amostras. Nas amostras processadas por álcool e antibiótico não foram observados danos na rede de colágeno pela aplicação da radiação. Os resultados dos testes biomecânicos apresentaram diferenças significativas entre os métodos aplicados. As amostras processadas com álcool e antibiótico apresentaram perda pouco significativa no módulo de elasticidade, comparadas às amostras processadas por ultrassom e peróxido de hidrogênio que mantiveram a propriedade viscoelástica. Contudo na dose de 12,5 kGy foi observado um aumento no módulo elástico e na viscoelasticidade. Com base nas análises, podemos concluir que o método de processamento com álcool, antibiótico e irradiação demonstrou menor dano, tanto na biomecânica quanto na esterilização, sendo que as amostras irradiadas a 15,0 e 25,0 kGy apresentaram características semelhantes ao controle não irradiado.

Palavras-chave: tendão, Banco de Tecido, esterilização, radiação ionizante 


\title{
MORPHOLOGICAL AND BIOMECHANICAL EVALUATION OF HUMAN TENDON TISSUE STERILIZED BY IONIZING RADIATION
}

\author{
Ana Paula Funari
}

\begin{abstract}
The increasing interest of development in less invasive surgical techniques, such as reconstructions of ligament tendon, has led to the increase of the research concerning the use of Allografts sterilized by ionizing radiation. Processing by ionizing radiation is a safe method and leaves no residues, being used as final sterilization. The present study was to evaluate the effects of proposed application of ionizing radiation, produced by ${ }^{60} \mathrm{Co}$ source in human tendon pre-samples processed multiorgans donors obtained through collaboration with tissue banks. The pre-processing of samples given by chemical methods and preserved by freezing at $-80^{\circ} \mathrm{C}$. The doses applied in radiation processing were 12.5, 15.0 and $25.0 \mathrm{kGy}$, each with your corresponding non-irradiated control. The samples were evaluated by means of histological and biomechanical testing, with the purpose of analyzing possible structural and morphological changes. The results showed that the ultrasound processing and hydrogen peroxide caused changes in the morphology of the tissues, which caused damage to the structure, making your samples. In the samples processed by alcohol and antibiotics were not observed damage on the network of collagen by the application of radiation. The results of biomechanical tests showed significant differences between the methods used. The samples processed with alcohol and antibiotics showed negligible loss in modulus of elasticity compared with the samples processed by ultrasound and hydrogen peroxide which kept the viscoelastic property, however in $12.5 \mathrm{kGy}$ dose was observed an increase in elastic modulus and viscoelasticity. Based on the analysis we can conclude that the method of processing with alcohol, antibiotics and irradiation showed less damage, both in biomechanics and sterilization, in the samples irradiated with 15.0 and $25.0 \mathrm{kGy}$, showing results similar to the non-irradiated control.
\end{abstract}

Keywords: tendon, tissue bank, sterilization, ionizing radiation 


\section{SUMÁRIO}

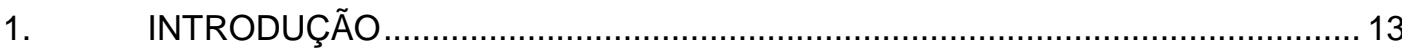

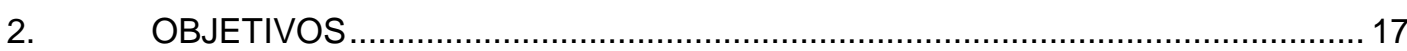

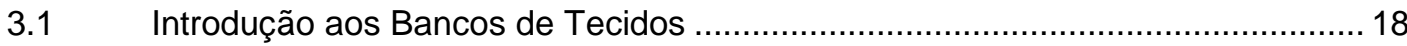

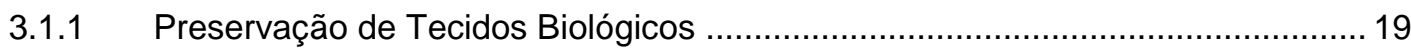

3.1.2 Processamento para Preservação dos Tecidos ................................................... 19

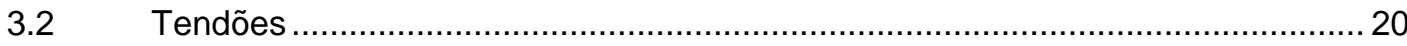

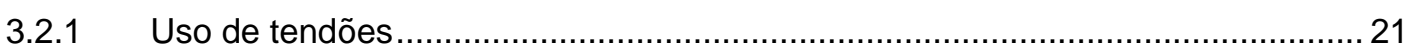

3.2.1.1 Características principais do tecido tendinoso ................................................. 22

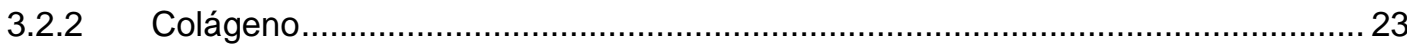

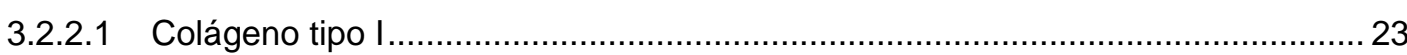

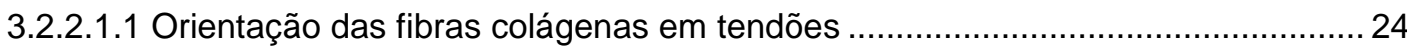

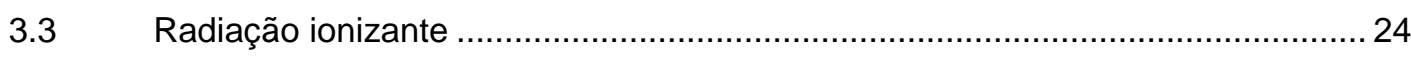

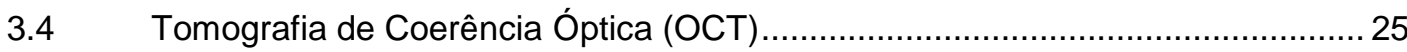

3.4.1 Análise de Tomografia de Coerência Óptica Sensível à Polarização (PS-OCT) 26

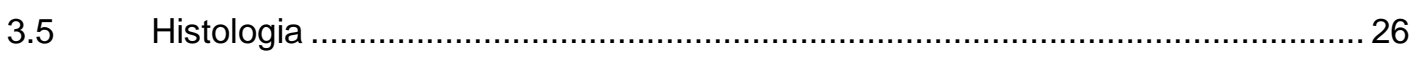

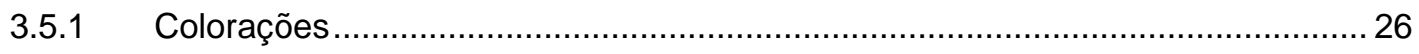

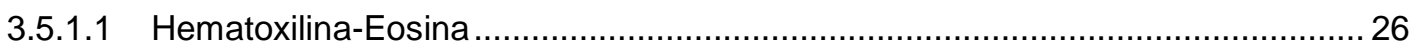

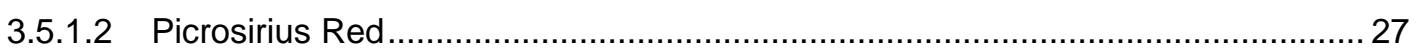

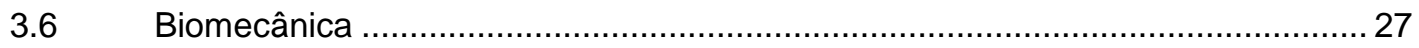

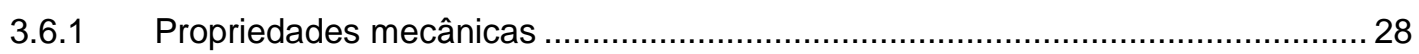

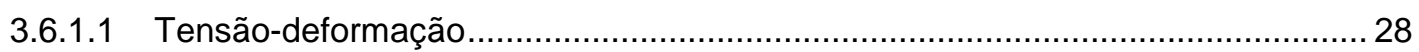

3.6.1.2 Módulo de elasticidade ou Módulo de Young ..................................................... 29

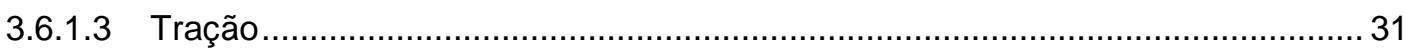

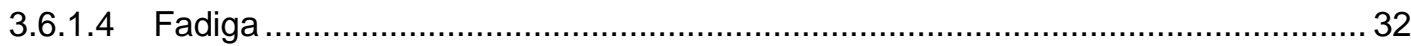

3.6.2 Máquina Universal de Ensaios - Instron ..................................................... 32

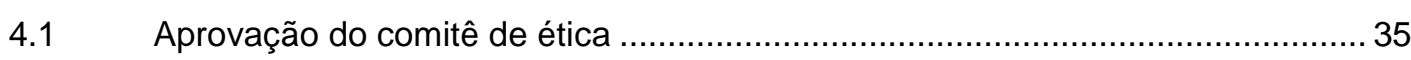

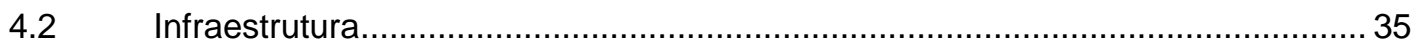

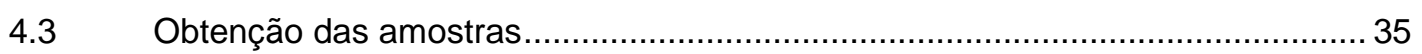

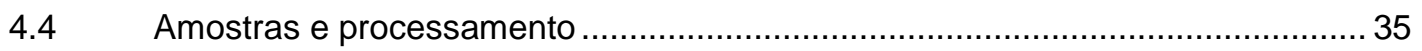

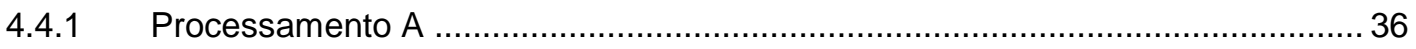

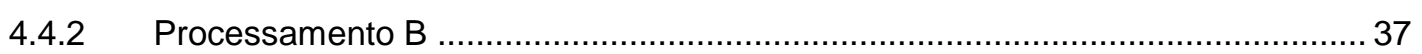

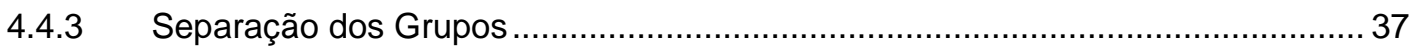

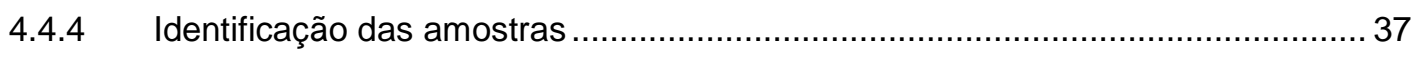

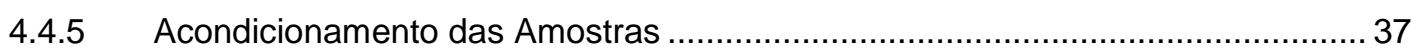

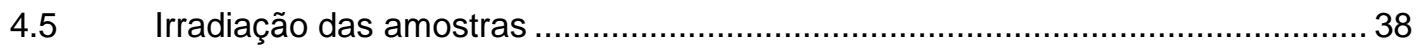

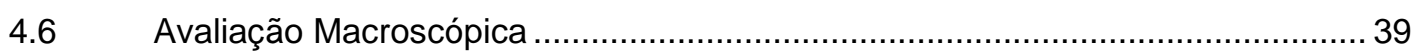

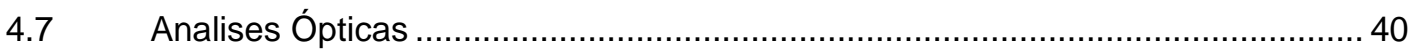

4.7.1 Tomografia de Coerência Óptica (OCT) …..................................................... 40

4.7.2 Análise de Tomografia de Coerência Óptica Sensível à Polarização (PS-OCT). 40 


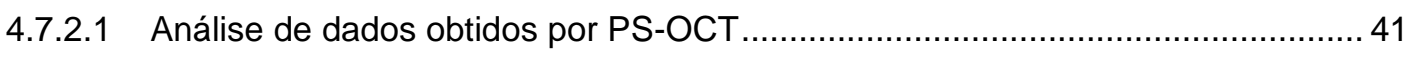

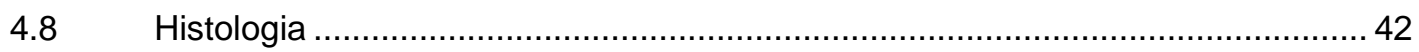

4.8.1 Processamento das amostras para histologia....................................... 42

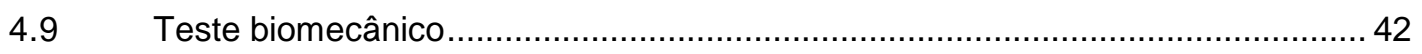

4.9.1 Tipos de Corpo de Prova .................................................................... 42

4.9.2 Dimensões do Corpo de Prova........................................................... 43

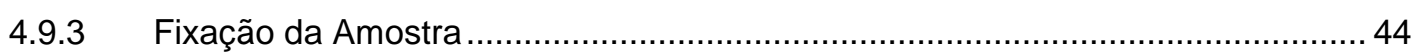

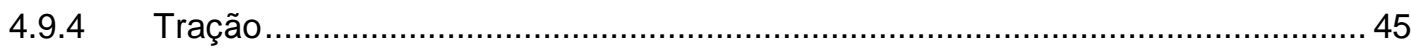

4.9.4.1 Teste de tensão-deformação ................................................................. 45

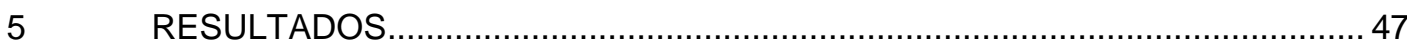

5.1 Análise macroscópica e Tomografia de Coerência Óptica (OCT) ..................... 47

5.2 Análise de Tomografia de Coerência Óptica Sensível à Polarização (PS-OCT). 48

5.2.1 Análise estatistica do dados .................................................................... 51

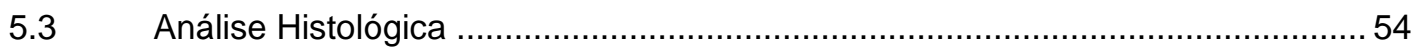

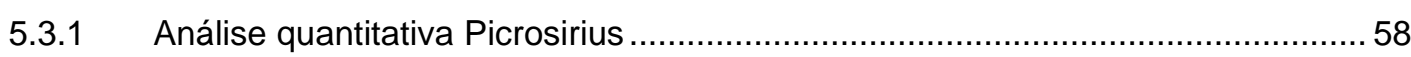

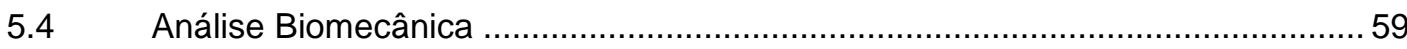

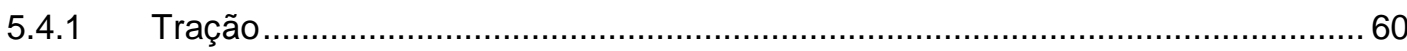

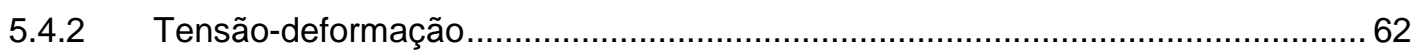

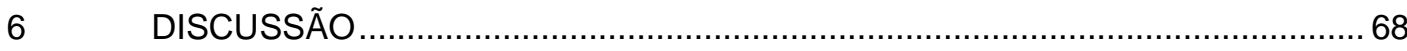

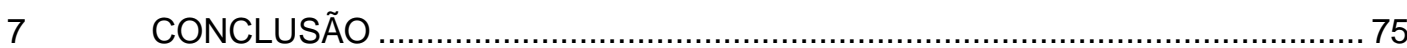

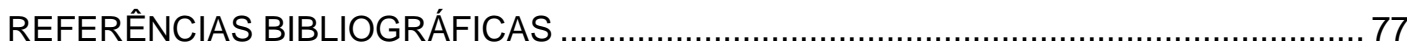

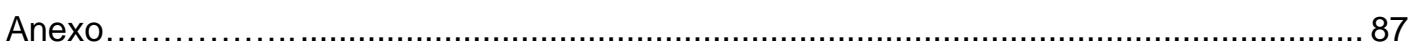

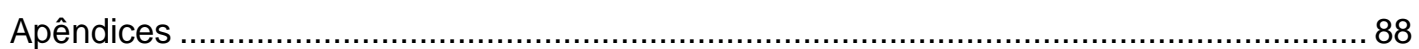




\section{LISTA DE FIGURAS}

FIGURA 1. Desenho esquemático representando como as moléculas de colágeno (tropocolágeno) se agregam para formar fibrilas, fibras e feixes.................................................. 22

FIGURA 2. Máquina de ensaios Instron modelo 3369 e Instron modelo 5567.................... 34

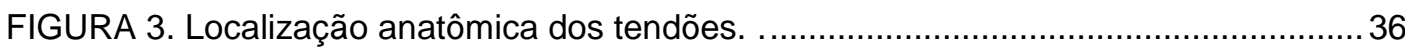

FIGURA 4. Foto do irradiador multipropósito localizado no Centro de Tecnologia das Radiações/IPEN. 38

FIGURA 5. Amostras irradiadas nas doses de 12,5, 15 e 25 kGy como mostra a etiqueta go/no go de controle.... 39

FIGURA 6. Imagem A medida realizada com auxílio do software. ......................................4 41

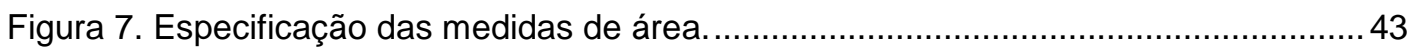

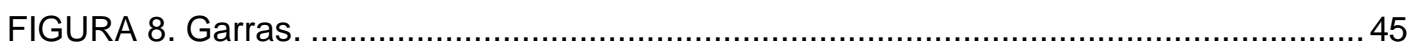

FIGURA 9. Gráficos de avaliação de comportamento de amostras. ..................................46

FIGURA 10. Imagem das amostras dos dois processamentos e em OCT ......................... 48

FIGURA 11. Imagens obtidas por PS-OCT amostra A processada pelo método A ............49

FIGURA 12. Imagens obtidas por PS-OCT amostra B processadas pelo método B. ........50

FIGURA 13. Gráficos comparativos das médias das distâncias entre as bandas de birrefringência. . .52

FIGURA 14. Gráfico de análise estatística dos dados das amostras (A) não irradiadas vs irradiadas. .53

FIGURA 15. Fotomicrografia tendão tibial posterior em cortes histológicos mostrando feixes paralelos e transversais de fibras colágenas (hematoxilina-eosina,100x e 200x). Erro!

\section{Indicador não definido.}

FIGURA 16. Fotomicrografia tendão tibial posterior em cortes histológicos mostrando feixes paralelos e transversais de fibras colágenas (Picrosirius 100x e 200x).............................56

FIGURA 17. Quantificação das imagens obtidas na análise das fotos de Picrosirius. ........58

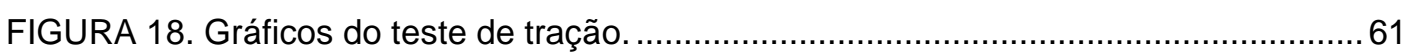

FIGURA 19. Análise de tensão deformação método $A$ e método $B$. ...................................64

FIGURA 20. Gráfico de comparação da tensão máxima x dose método A e B. ..................65

FIGURA 21. Gráfico do módulo elástico das amostras dos métodos A e B. .......................66

FIGURA 22. Gráfico de comparação módulo elástico das três taxas diferentes de deformação dos métodos $A$ e $B$. 66 


\section{LISTA DE TABELAS}

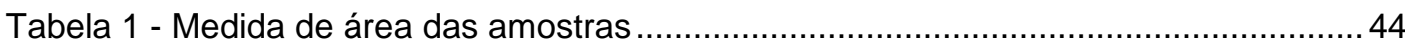

Tabela 2 - Comparação grupo controle e grupo irradiado............................................... 51

Tabela 3 - Comparação grupo não irradiado e grupo irradiado …….................................5

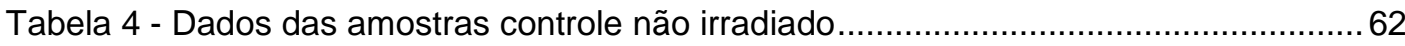

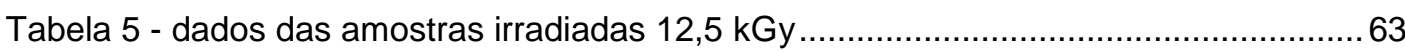

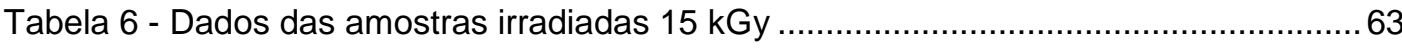

Tabela 7 - Dados das amostras irradiadas 25 kGy ....................................................... 63 


\section{LISTA DE QUADROS}

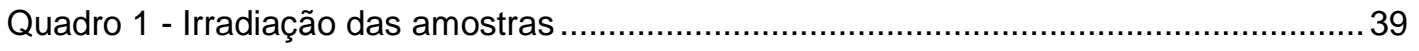

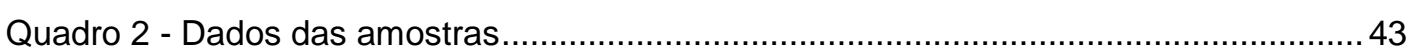




\section{LISTA DE ABREVIATURAS}

ANOVA = Analise de variância unifatorial

DNA = Ácido desoxirribonucleico

$\mathrm{HE}=$ Hematoxilina e eosina

IAEA = Agência Internacional de Energia Atômica

ICB = Instituto de Ciências Biomédicas

IPEN = Instituto de Pesquisas Energéticas e Nucleares

OCT = Tomografia de Coerência Óptica

PS-OCT = Tomografia de Coerência Óptica Sensível à Polarização

$\mathrm{MPa}=$ Mega Pascal 


\section{INTRODUÇÃO}

O presente trabalho teve como foco avaliar os efeitos da radiação ionizante, produzida por meio de fonte de ${ }^{60} \mathrm{Co}$, nos tendões humanos processados por diferentes métodos e preservados por meio de congelamento, a fim de determinar qual a dose mais segura, evitando alterar suas propriedades, para esterilidade e preservação.

Para isso utilizou-se de diferentes técnicas para avaliação dos tecidos, como: Tomografia de Coerência Óptica (OCT), para avaliação de sua estrutura morfológica, a Tomografia de Coerência Óptica sensível à polarização (PS-OCT), com a qual se verificou o direcionamento das fibras deste tecido, testes histológicos e biomecânicos para averiguar se o tecido sofreu alguma modificação estrutural devido ao tipo de processamento ou à esterilização por radiação ionizante.

O Brasil é um país com mais de 190.000 .000 de habitantes, com um sistema de saúde governamental composto por uma grande gama de pacientes. Entre 1999 e 2010 o número de doadores de tecidos aumentou cerca de 160\%, de 3 para 9,9 por milhão de habitantes, com aumento no número de órgãos transplantados de 121\%, de 2891 para 6402 (Silva Jr e col., 2011).

Esse crescimento ocorreu em consequência da criação do programa de transplante nacional muito bem organizado. O financiamento do governo, a descentralização e o investimento no ensino de coordenadores de transplantes e profissionais mais qualificados foram decisivos (Silva Jr e col., 2011).

A doação de tecido para melhorar a qualidade de vida das pessoas é um ato de altruísmo, o qual acarreta um compromisso e comportamento ético de todas as atividades que culminam com o uso de tecido humano para propósitos terapêuticos, de investigação ou ensino (Saldías, 2013).

O aparecimento formal dos bancos de tecidos ocorreu há aproximadamente 60 anos nos Estados Unidos e em alguns países da Europa (Monig e Von Versen, 2000).

Os Bancos de Tecidos são instituições que se responsabilizam pela seleção de doadores, captação, processamento, esterilização, armazenamento e distribuição de tecidos utilizados em cirurgias reconstrutivas que necessitam de 
aloenxertos. Os Bancos de Tecidos podem ser dedicados a um único tipo de tecido, como Banco de Olhos, Banco de Esperma, Bancos Cardiovasculares, Banco de Embriões, Bancos Musculoesqueléticos ou Bancos de Pele. Existem também bancos gerais ou multi-tecidos que suprem diversos tecidos (Vangness Jr, 2003).

Com o crescente interesse no desenvolvimento de técnicas menos invasivas para as cirurgias de reconstruções tendíneas e ligamentares, a pesquisa relativa à utilização de aloenxertos tem aumentado (Reiff e col., 2007).

Enxertos de tendões podem ser obtidos pela captação de tecidos de doadores de múltiplos órgãos ou de coração parado.

Existem vantagens significativas na utilização de enxertos obtidos por meio de doação de múltiplos órgãos, como por exemplo, a dos coordenadores de transplantes de tecidos serem capazes de assegurar que os doadores sejam adequadamente identificados e examinados. Além dos enxertos serem coletados assepticamente usando protocolos padrão de sala de cirurgia (Robertson e col., 2006).

Porém, com a utilização de aloenxertos existe o risco de contrair doenças infecciosas a partir do doador, como também há a possibilidade de serem introduzidos microrganismos durante a captação, processamento, preservação e armazenamento dos tecidos (Dahlan, 2001).

Com o propósito de eliminar a contaminação em potencial, a triagem do doador é essencial, em conjunto com técnicas cirúrgicas assépticas durante a captação do tecido, processamento e armazenamento (Nguyen e Morgan, 2007).

Aloenxertos musculoesquelético são usualmente desinfetados por meio do uso de antibióticos, irradiação ou métodos químicos variando de acordo com os protocolos dos bancos de tecidos.

Como parte do processamento, muitos bancos consideram necessária uma esterilização final por meio de radiação ionizante, em geral a partir de fontes de cobalto-60 (Nguyen e Morgan, 2007).

Segundo Pedraza (2012) tecidos esterilizados podem ser utilizados para os seguintes propósitos: diagnostico (por exemplo, testar os efeitos no tecido de alguns produtos como cosméticos e medicamentos), terapêutico e pesquisa. 
A esterilização por radiação ionizante é o método que proporciona um aumento mínimo da temperatura e não deixa resíduos tóxicos, o que a torna passível de ser usada, além de ser uma esterilização final, ou seja, na embalagem final, evitando o perigo da recontaminação por manipulação após a esterilização (Dziedzic-Goclawska, 2000).

De maneira geral o valor da dose de esterilização depende da carga microbiana inicial, da resistência dos microrganismos ao método de esterilização e do nível de segurança de esterilidade (SAL - Security Assurance Level) necessário (International Atomic Energy Agency, IAEA, 2004).

A esterilização de aloenxertos é necessária para reduzir o risco de transmissão de agentes infecciosos. Sendo um método definitivo para eliminação de microrganismos e podendo prevenir risco de vida por infecções associadas a estes (Dziedzic-Goclawska e col., 2005). Diferentes técnicas de esterilização têm sido utilizadas para prevenir infecções por aloenxertos, incluindo a radiação gama (Nguyen e Morgan, 2007), gás óxido de etileno (Arizono e col., 1994), tratamento térmico com calor úmido, beta-propiolactona (Geesink, 2002), processamento químico e com antibióticos (Tom e Rodeo, 2002)

O emprego do óxido de etileno é altamente eficiente para a eliminação de microrganismos, porém existem limitações quanto ao seu uso por ser um composto tóxico, com potencial cancerígeno, teratogênico, mutagênico e neurotóxico. Durante o processo de esterilização, podem ser formados subprodutos como, etileno cloridrina e etileno glicol, dois compostos tóxicos e de difícil remoção (Possari, 2003).

A esterilização por calor úmido está associada com vapor de água ou somente água em ebulição, é uma técnica rápida e eficaz, porém sua principal desvantagem ocorre pelo próprio mecanismo de ação, o calor pode causar danos e alterações ao material. Não sendo recomendado seu uso em tecidos biológicos devido às altas temperaturas envolvidas. (Philips, 1997).

$\mathrm{O}$ processamento de materiais embebidos com produtos químicos e antibióticos tem certas limitações para esterilização de aloenxertos devido às limitações de penetração completa no material para inativação total da carga microbiológica (Fölsch e col., 2015). 
Os padrões da IAEA reconhecem o fato de que diversas instalações de irradiação estão disponíveis para esterilização de tecidos processados por bancos, utilizando a técnica de radiação ionizante, por meio da aplicação de diferentes doses de radiação.

De acordo com a ISO 11.137, quando o resultado de carga microbiana for igual a zero unidades formadoras de colônia a dose mínima de 15 kGy pode ser aplicada. Os níveis de segurança recomendados na ISO 11.137 de 2006 são de $10^{-6}$ (SAL $10^{-6}$ ) ou seja, a probabilidade de se encontrar uma parte por milhão de unidade formadora de colônia após o processo de esterilização. Segundo Pedraza (2012) alguns especialistas relatam que a dose mínima recomendada para descontaminação bacteriana para alguns tecidos específicos é 15 kGy, e a dose mínima para recomendada para esterilização bacteriana é 25 kGy comumente utilizada em diversos países. Alguns especialistas consideram que após a triagem do doador e processos rigorosos e processamento de determinados tecidos, uma dose entre 15 e $50 \mathrm{kGy}$ pode ser utilizada com propósito de esterilização. Sendo que a recomendação da dose de 25 kGy para esterilização de tecidos é baseada em "bioburden" e na resistência de microrganismos a radiação (Pedraza, 2012).

Portanto, torna-se importante estudar as possíveis alterações causadas no tecido após o procedimento de esterilização por radiação ionizante em diferentes doses, de modo a determinar a dose adequada para esterilização desse tecido, proporcionando segurança na esterilidade e na estrutura do material a ser utilizado para transplante. 


\section{OBJETIVOS}

O trabalho teve por objetivo estudar os efeitos da aplicação de radiação ionizante, produzida através de fontes de ${ }^{60} \mathrm{Co}$, nas doses de $12,5 \mathrm{kGy}, 15 \mathrm{kGy}$ e $25 \mathrm{kGy}$ em tecido tendinoso humano processado por dois métodos diferentes e preservados por congelamento, determinando assim a dose mais segura para esterilização e preservação das suas características.

Utilizando-se das seguintes técnicas para avaliação: análise por Tomografia por Coerência Óptica sensível à polarização, testes histológicos e testes biomecânicos de tração, fazendo análise dos dados obtidos entre as amostras e seus respectivos controles. 


\section{CONSIDERAÇÕES GERAIS}

\subsection{Introdução aos Bancos de Tecidos Musculoesqueléticos}

No Brasil é obrigatório que estas instituições estejam localizadas em hospitais ou em hemocentros e o Sistema Nacional de Transplantes (SNT) e a Agência Nacional de Vigilância Sanitária (ANVISA) se responsabilizam pelo credenciamento e pela fiscalização, respectivamente, dos bancos de tecido, de acordo com as leis:

Lei $n^{\circ} 9.434$ de 4 de fevereiro de 1997, "Dispõe da remoção de órgãos, tecidos e partes do corpo humano para fins de transplante ou tratamento e dá outras providencias" (Brasil, Lei no $9.434,1997$ ).

Lei $n^{\circ} 10.211$ de 23 de março de 2001 que "Altera o dispositivo da Lei $n^{\circ}$ 9.434 de 4 de fevereiro de 1997, que "Dispõe sobre a remoção de órgãos e tecidos e partes do corpo humano para fins de transplante e tratamento" (Brasil, Lei oㅜ 10.211, 2001).

Portaria $n^{\circ} 2600$ de 21 de outubro de 2009. "Regulamento Técnico do Sistema Nacional de Transplantes" (Brasil, Portaria ํㅡ 2600, 2009).

RDC $n^{\circ} 55$, de 11 de dezembro de 2015. Dispõe sobre as boas práticas em tecidos humanos para uso terapêutico.

O processamento destes tecidos tem por objetivo efetuar a limpeza, para eliminar todas as partes moles, inserções musculares e periósteos (Ross e col., 2000).

A segurança do enxerto, incluindo o desenvolvimento de métodos de esterilização terminal, continua a ser uma grande preocupação entre a comunidade de banco de tecidos (Seto e col., 2012).

A maior complicação a ser evitada é a transmissão de doenças do doador ao receptor, seja de natureza viral (HIV, hepatite) ou bacteriana, causadas por um organismo presente no doador ou por contaminação no momento da captação dos tecidos esqueléticos (Alencar e Vieira, 2010). O fator mais importante no transplante de tecidos músculo esqueléticos é a segurança do receptor, que depende da seleção adequada dos doadores. A coleta é um procedimento invasivo e o risco de contaminação dos tecidos é real (Dahlan, 2001). 


\subsubsection{Preservação de Tecidos Biológicos}

Os diferentes métodos utilizados para preservação de tecidos variam de acordo com os tecidos e com o propósito de seu uso. O objetivo principal da preservação de tecidos biológicos é que o mesmo conserve as propriedades biológicas e mecânicas (Phillips, 1997).

Estes métodos podem ser: congelamento, conservação em glicerol em concentrações altas, liofiliização, entre outros.

Estes processos são levados a cabo no setor de preparação de tecido do próprio banco, de acordo com as boas práticas de fabricação e boas práticas laboratoriais.

\subsubsection{Processamento para Preservação dos Tecidos}

Os métodos para preservação do tecido variam de acordo com o tipo de tecido e seu propósito de uso. Visando a conservação das propriedades biológicas e mecânicas. Tecidos podem ser processados e armazenados por meio de métodos como, congelamento, glicerol, criopreservação e liofilização (Herson e col., 2002).

A liofilização consiste na remoção do conteudo de água do tecido, sendo uma técnica mais drástica que a preservação em glicerol (Dziedzic-Goclawska e col., 2005).

O congelamento a $-80{ }^{\circ} \mathrm{C}$ esta entre uma das formas de preservação utilizadas pelos Bancos de Tecidos, uma das vantagens desta técnica é a sua praticidade, pois necessita de poucos recursos físicos, possibilitando a preservação dos tecidos por um longo período (Macedo e col., 1999)

Outros agentes como calor, radiação ultravioleta ou exposição a antibióticos podem ser usados como agentes de desinfecção. Procedimentos para processamento com tais agentes químicos devem ser documentados e validados para garantir a consistência no processamento do tecido. 
No caso dos antibióticos pode ser utilizada por exemplo a Vancomicina que é um antibiótico glicopeptídeo com um alto volume de distribuição e é solúvel em água. Tem uma taxa baixa de alergia, é estável ao calor e tem baixa taxa de resistência entre as bactérias gram-positivas. É menos tóxica aos tecidos do que a cefazolina, tobramicina e gentamicina (Andrews, 2001).

\subsection{Tendões}

Tendões apresentam-se em vários tamanhos e formatos. Como regra geral tendões extensores são mais achatados que tendões flexores que tendem a ser redondos ou ovais (Benjamin e col., 2008). Tendões são compostos de colágeno, sendo que o colágeno do tipo I é o mais frequente. As fibras colágenas do tipo I aparecem agrupadas em arranjo paralelo formando feixes. Essas fibras são birrefringentes, por serem constituídas por moléculas alongadas e paralelas (Junqueira e Carneiro, 2008).

Os tendões podem sofrer alterações por diferentes fatores, como por exemplo, doenças metabólicas como o diabetes mellitus (DM), influenciando diretamente o sistema musculoesquelético. Os impactos negativos da DM sobre os tendões podem levar à ruptura dos mesmos. Causas raras de ruptura destes tendões podem ser induzidas pelo uso de medicamentos, como os da família das quinolonas $(0,02-2,0 \%)$ e as associadas a doenças sistêmicas (Freedman e col., 2014).

Os tendões fibular longo e curto se originam da superfície lateral da fíbula. Distal à fíbula, os tendões viajam dentro de bainhas individuais, separadas pela tróclea fibular na superfície lateral do calcâneo. Ambos atuam como flexores plantar da articulação do tornozelo e musculo do pé. Durante a carga, o fibular longo atua na estabilidade do arco transversal do pé, bem como na estabilização durante a propulsão (Scanlan e Gehl, 2002).

O tendão tibial posterior se origina no terço superior da perna, na borda posterior da tíbia, fíbula e membrana interóssea (Gluck e col., 2010).

Sob condições fisiológicas normais, as funções primárias do musculo/tendão tibial posterior, através de seus vários anexos no aspecto plantar 
do pé, são supinação da articulação subtalar, adução do pé médio, e flexão plantar do tornozelo (Shane e col., 2016).

É comumente aceito que a idade do doador afetará as propriedades mecânicas do tecido, mas aparentemente este limite de idade é desconhecido. Assim, muitos cirurgiões ortopédicos preferem obter tecidos provenientes de doadores mais jovens (a idade mínima para doador é de 18 anos e a máxima é de 55 anos) (Swank e col., 2015).

\subsubsection{Uso de tendões}

Os aloenxertos tendinosos desempenham um papel importante na reconstrução do tendão e do ligamento, particularmente onde existe uma escassez de tecido local disponível. Embora atualmente usado predominantemente para reconstrução do ligamento ao redor do joelho, (Wascher e col., 1999, Harner e col., 1996) eles têm indicações ocasionais no membro superior e em outros lugares. (Sanchez-Sotelo e Morrey, 2002, Joseph e col., 2003).

As vantagens da utilização de tecido de aloenxerto incluem a falta de morbidade no local de retirada, alta resistência à tração, diminuição do tempo cirúrgico, incisões cirúrgicas menores e baixo risco de artrofibrose. As desvantagens incluem a sua disponibilidade limitada, elevado custo, susceptibilidade à rejeição devido a imuno-incompatibilidade entre o doador e receptor e risco potencial para a transmissão de doenças (Harner e col., 1996).

O processo de integração do aloenxerto é significativamente afetado pelo método de processamento do tecido. $O$ tecido de aloenxerto fresco não é adequado para implante porque é altamente imunogênico e a tipagem de tecidos é impraticável. Os processos de congelamento, secagem por liofilização ou criopreservação de tecido de aloenxerto reduzem significativamente a imunogenicidade do tecido ao matar as células dentro dele, permitindo que os aloenxertos sejam usados em hospedeiros imunologicamente incompatíveis sem provocar uma resposta imune significativa (Arnoczky e col., 1986). 


\subsubsection{Características principais do tecido tendinoso}

Tendões são estruturas anatômicas interpostas entre o músculo e o osso, transmitindo a força criada no músculo para o osso e dessa forma possibilitando o movimento. Basicamente, cada músculo tem dois tendões: proximal e distal. O ponto de união com o músculo é chamado de junção miotendínia (MTJ), e o ponto de junção com o osso de junção osteotendinea (OTJ) (Kannus, 2000).

Os tendões humanos são compostos por um arranjo denso de fibras colagenas, elastinas e proteoglicanas, com colágeno tipo I como proteína dominante do tecido conjuntivo (Andersen, e col., 2011). No estado fresco são brancas, conferindo essa cor aos tecidos nos quais predominam. A cor branca dos tendões deve-se a sua riqueza em colágeno. Essas fibras são birrefrigentes, pois são constituídas por moléculas alongadas e paralelas. Em muitos tecidos, as fibras colágenas do tipo I aparecem agrupadas em arranjo paralelo formando feixes (FIG. 1) (Junqueira e Carneiro, 2013).

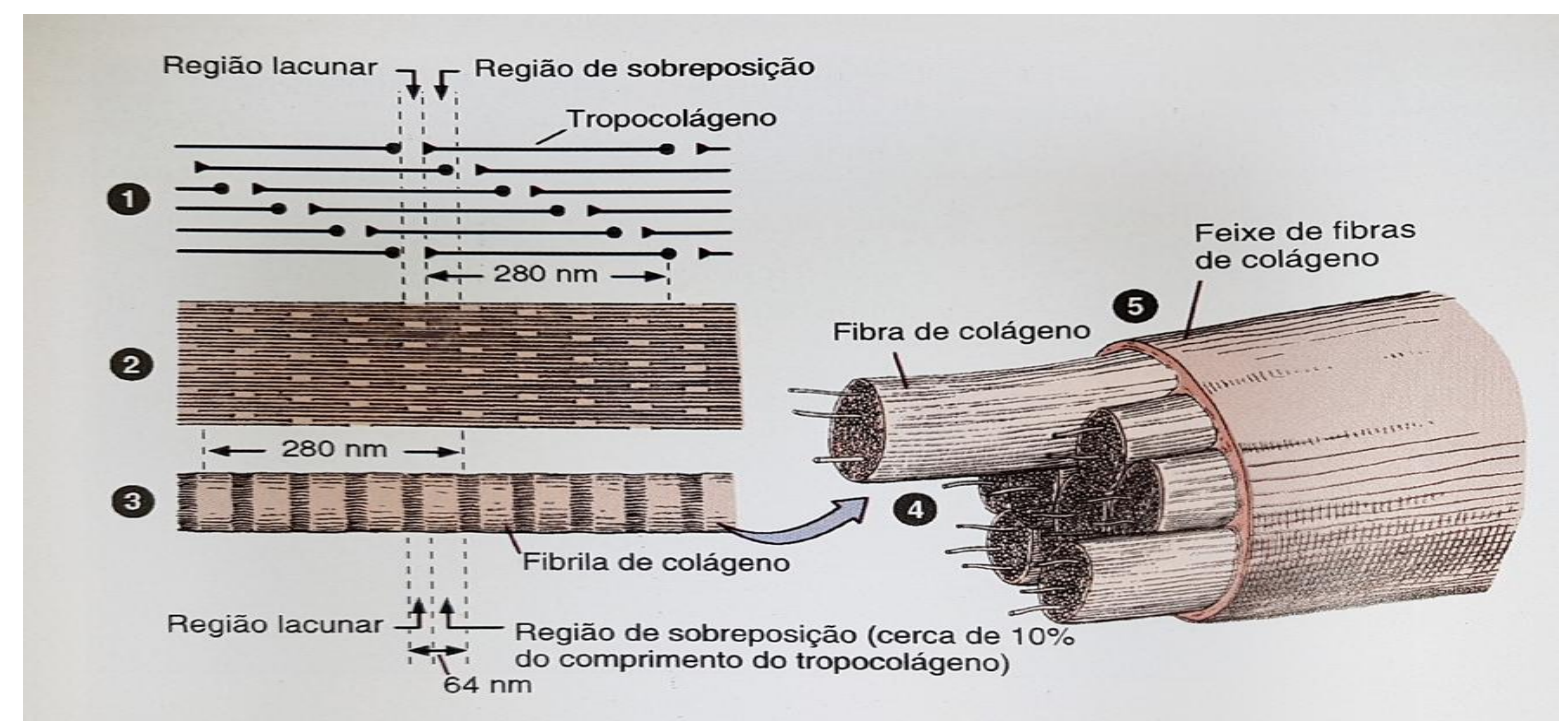

FIGURA 1. Desenho esquemático representando como as moléculas de colágeno (tropocolágeno) se agregam para formar fibrilas, fibras e feixes. Cada uma das unidades de tropocolágeno mede $280 \mathrm{~nm}$ de comprimento e se sobrepõem umas às outras (A). Este arranjo resulta em regiões de sobreposição e regiões lacunares (B) que resultam na estriação transversal característica da fibrila de colágeno com faixas claras e escuras que se alternam a cada $64 \mathrm{~nm}$, como observado ao microscópio eletrônico (C). Os agregados de fibrilas formam as fibras (D) que tornam a se agregar para formar os feixes (E) rotineiramente denominados de fibras de colágeno. Fonte: Junqueira e Carneiro, 2013. 


\subsubsection{Colágeno}

O colágeno é a família de proteínas mais abundante do organismo, representando cerca de $30 \%$ do seu peso seco. Eles diferenciam entre si pela composição química, características morfológicas, distribuição, funções e patologias (Sampaio e Rivitti, 2007).

Os três principais tipos de fibras do tecido conjuntivo são as colágenas, as reticulares e as elásticas. As fibras colágenas e as fibras reticulares são formadas pela proteína colágeno e as fibras elásticas são compostas essencialmente pela proteína elastina.

$\mathrm{Na}$ verdade, existem dois sistemas de fibras: o sistema colágeno, constituído por fibras colágenas e reticulares, o sistema elástico que é formado pelas fibras elásticas, elaunínicas e oxitalânicas. Muitas vezes a propriedade do tecido é dada pelo tipo dominante de fibra, como ocorre com o tecido elástico, variedade de tecido conjuntivo dotado de grande elasticidade, por ser rico em fibras elásticas.

O colágeno compõe um tipo de família de proteínas selecionadas durante a evolução para desempenhar diversas funções principalmente estruturais. Durante o processo de evolução dos organismos, a família de um grupo de proteínas estruturais, sob efeito do meio ambiente e pelas necessidades funcionais do organismo dos animais, transformou-se e adquiriu diferentes graus de rigidez, elasticidade e força de tensão. Este conjunto de proteínas é conhecido coletivamente como colágeno, e os principais exemplos destes vários tipos de colágeno são encontrados em pele, osso, cartilagem, musculo liso e lâmina basal (Junqueira e Carneiro 2013).

\subsubsection{Colágeno tipo I}

O colágeno do tipo I é predominante, sendo amplamente distribuído no organismo. Aparecendo como estruturas classicamente denominadas de fibrilas de colágeno que dão origem a osso, dentina, tendões, capsulas de órgãos e derme, entre outros (Junqueira e Carneiro, 2013). 
As moléculas se agrupam formando fibrilas de colágeno que são estruturas dispostas em feixes finos e se juntam formando as fibras de colágeno (Alberts, e col., 2002).

\subsubsection{Orientação das fibras colágenas em tendões}

O arranjo espiral divergente das fibras superficiais que envolvem o tendão flexor foi ilustrado por Leonardo da Vinci (1452-1519) em estudos anteriores ao do mecanismo da mão no século 15.

Atualmente com o uso da microscopia eletrônica de varredura, pode ser bem documentado que as fibras colágenas não são orientadas somente longitudinalmente, mas também transversalmente e horizontalmente com as fibrilas longitudinais, também cruzando entre si, formando espirais e tranças (Kannus, 2000).

\subsection{Radiação ionizante}

A radiação ionizante é um tipo de radiação que tem energia suficiente para retirar elétrons de átomos, moléculas e converte-los em partículas eletricamente carregadas, denominadas íons. Essas reações dão origem a radicais livres que usualmente podem ser reativos levando a modificações químicas da matéria.

A radiação ionizante pode ser obtida a partir de duas diferentes fontes: a) radioisótopos e b) máquinas de descargas elétricas. Os mais comuns radioisótopos usados comercialmente são o cobalto-60 $\left({ }^{60} \mathrm{Co}\right)$ e o césio-137 $\left({ }^{137} \mathrm{Cs}\right)$ (Dahlan, 2001; Drobny, 2012).

A esterilização por radiação ionizante é um método físico, onde ocorre aumento moderado da temperatura, o que o torna possível de ser usado.

A eficácia da utilização da radiação como método de esterilização é decorrente da sua grande capacidade de penetração na matéria e de sua alta eficiência em inativar microrganismos. Além de permitir a esterilização de 
materiais que estejam em embalagens previamente fechadas, desta forma prevenindo uma recontaminação posterior.

A esterilização por radiação ionizante depende da quantidade de energia transferida, do número de microrganismos presentes e da resistência dos microorganismos frente ao método de esterilização definido pelo termo D10 (DziedzicGoclawska e col., 2005).

A dose utilizada usualmente é a de 25 kGy para esterilização de tecidos biológicos, objetivando a inativação de fungos e bactérias. Levando-se em consideração que altas doses de radiação ionizante (acima de 40 a 50 kGy) podem provocar varias alterações químicas e físicas, podendo diminuir também as propriedades biomecânicas (Dziedzic-Goclawska, 2001).

No entanto, o Banco de Tecidos Central em Warsaw utiliza, desde 1963, doses de 33 kGy $\pm 10 \%$ para a esterilização dos tecidos. Essa mesma dose é utilizada em outras unidades regionais de Bancos de Tecidos na Polônia (Dziedzic-Goclawska e col., 2005).

Por outro lado é possível utilizar doses mais baixas, como por exemplo 15 kGy se a dosagem de carga microbiologica inicial for igual a zero (ISO 11137, 2006).

\subsection{Tomografia de Coerência Óptica (OCT)}

A Tomografia de Coerência Óptica (OCT) é uma tecnologia para obtenção de imagens em escala microscópica. Este tipo de técnica é capaz de gerar imagens de secções transversais de sistemas biológicos sem a necessidade de preparação previa do material a ser analisado (Huang e col., 1991). Por ser uma técnica óptica, o OCT consegue uma resolução espacial de até $10 \mu \mathrm{m}$, representando uma resolução cerca de 10 vezes maior do que a do ultrassom convencional. (Fujimoto e col., 1995).

A medição realizada no equipamento com um feixe de luz incide em um ponto especifico da amostra, produzindo uma medida de variação da reflexão óptica ao longo do eixo do feixe. Produzindo uma imagem da secção transversal do tecido de maneira similar ao radar: um feixe de luz é lançado no tecido e os perfis de reflexão de diversas posições transversas são gravados no 
microcomputador. O resultado é uma representação bidimensional da secção transversal do tecido (Fujimoto e col., 1995).

\subsubsection{Análise de Tomografia de Coerência Óptica Sensível à Polarização (PS-OCT)}

A Tomografia por Coerência Óptica sensível a polarização (PS-OCT) é um modo funcional de OCT, que baseado na variação do ângulo de incidência da iluminação, fornece dados sobre o estado de polarização de luz retroespalhada (Prasad, 2003). De tal modo, com a variação do ângulo de incidência de luz, pode-se mapear a orientação de estruturas biológicas birrefringentes, como o colágeno (Ugryumova e col., 2006). Revelando dados sobre a organização e integridade da matriz de colágeno e possíveis alterações em sua estrutura ou na viabilidade dos tecidos (Boer e col., 1997).

\subsection{Histologia}

A histologia é o estudo dos tecidos do corpo e de como estes tecidos são organizados para a construção de órgãos. Estes tecidos são formados por células e matriz extracelular (Junqueira e Carneiro, 2013).

\subsubsection{Colorações}

\subsubsection{Hematoxilina-Eosina}

Dentre todos os corantes, a combinação de hematoxilina e eosina (HE) é a mais comumente usada. A hematoxilina cora em luz azul ou violeta o núcleo das células e outras estruturas ácidas (como porções do citoplasma ricas em RNA e a matriz de cartilagem hialina). A eosina, por outro lado, cora o citoplasma e o colágeno em cor de rosa (Junqueira e Carneiro, 2013). 


\subsubsection{Picrosirius Red}

Os possíveis benefícios de coloração de tecidos conjuntivos com Sirius Red foram estudados há um quarto de século (Sweat e col., 1964; Weatherford, 1972). Observando feixes de colágeno sob luz polarizada, este revelou uma forte birrefringência com as cores amarelo-vermelho ou verde (Constantine e Mowry, 1968). Uma década depois, e até recentemente, algumas interpretações foram dadas para as cores das fibras (Bonafe e col., 1981; Junqueira e col., 1978, 1979, 1980; Montes et al, 1980; Pieraggi e Bonafè, 1982). Esta técnica pode distinguir os tipos de colágeno I, II e III, em secções de tecido (Junqueira e col., 1978; Junqueira e col., 1979).

A coloração por Picrosirius está associada à análise morfométrica das imagens. Muitos estudos identificam os tipos de colágeno de acordo com suas cores sob luz polarizada, por exemplo, fibras mais grossas nas colorações alaranjada, rosa e avermelhado e fibras mais finas, verde e azulado (Coleman, 2011). Portanto esta coloração pode ser empregada em histologia como específica para colágeno, aumentando a birrefringência deste material (Almeida e col., 1988).

\subsection{Biomecânica}

Amadio (1989) descreve a Biomecânica como a disciplina cujo objetivo é a análise física do movimento dos sistemas biológicos, aplicando os princípios da mecânica na análise de um sistema que possui particularidades fisiológicas e anatômicas bem definidas. Os tecidos biológicos, que apresentam em sua estrutura uma quantidade significativa de colágeno, apresentam como propriedades mecânicas: a elasticidade, viscoelasticidade e/ou plasticidade (Engles, 2001 apud Aquino e col., 2005). A propriedade mecânica de elasticidade é definida como a capacidade de um material, após deformado, retornar ao seu comprimento e forma originais após a retirada de uma carga. Portanto, em um material elástico, a deformação ocorre no instante em que há uma aplicação de 
carga externa e, após a remoção dessa força, a recuperação é imediata (Taylor e col., 1990; Aquino e col., 2005).

\subsubsection{Propriedades mecânicas}

Em grande parte das aplicações de materiais na área biomédica, as características de maior relevância são as propriedades mecânicas e a reatividade química. $\mathrm{O}$ comportamento mecânico dos materiais, por muitas vezes, é decisivo na escolha do material para uma determinada aplicação. Este comportamento mecânico pode variar de acordo com características da solicitação, como por exemplo, a velocidade de aplicação da força, da temperatura em que o material de encontra além do histórico de tratamentos químicos e/ou térmicos aplicados (Oréfice e col., 2012).

A maneira mais comum para determinar como o material vai se comportar quando submetido a cargas é através de experimentos laboratoriais. $O$ experimento mais comum consiste em submeter uma amostra do material a um teste mecânico, aplicando um deslocamento ou força sobre o mesmo, e mensurando a resposta mecânica da amostra (Gere, 2009). Apesar do carácter experimental, para o prosseguimento deste trabalho, serão revisados brevemente conceitos primordiais da mecânica dos sólidos, como o tipo de carregamento (tração, compressão, cisalhamento), tensão, deformação, módulo elástico, tensão de ruptura, etc.

\subsubsection{Tensão-deformação}

Quando um sólido está sujeito a forças externas, ele sofre uma mudança de forma, denominada deformação. Se ao final da atuação das forças externas, o sólido retorna à sua forma inicial, tem-se uma deformação elástica. Se após a aplicação destas forças o sólido não volta a sua forma inicial, tem-se uma deformação permanente (plástica).

O valor da deformação de engenharia, que quantifica a variação da forma do corpo colocado a forças externas, $e$ é definido por: 


$$
e=\frac{(l-l o)}{l o}=\frac{\delta l}{l o}
$$

no qual $\delta l$ é a extensão ou variação de comprimento e lo é o comprimento inicial.

As forças externas não podem ser relacionadas diretamente com a deformação, uma vez que uma mesma força aplicada sobre superfícies de áreas diferentes gera deformações diferentes. Desta forma, define-se a tensão mecânica de engenharia $\sigma$ por:

$$
\frac{F}{A}=\sigma
$$

no qual a força $F$ é aplicada perpendicularmente em uma área inicial $A$.

\subsubsection{Módulo de elasticidade ou Módulo de Young}

O módulo de elasticidade, módulo elástico ou módulo de Young é a razão entre a tensão e a deformação na direção da carga aplicada, sendo que a tensão não pode ser suficiente grande para gerar deformação permanente.

O comportamento elástico de materiais é representado pela lei de Hooke, modelando o comportamento do material semelhante ao de uma mola. Nesta lei, conforme explicado anteriormente, a tensão de engenharia $\sigma$ é diretamente proporcional a força aplicada $(F)$ e inversamente proporcional a área inicial da seção perpendicular à aplicação da força $(A)$. Já a deformação de engenharia $e$ é diretamente proporcional à variação de comprimento $\delta l$ e inversamente proporcional ao comprimento inicial $(l o)$. Tais proporcionalidades acabam gerando a seguinte equação que caracteriza o comportamento elástico:

$$
\frac{F}{A}=\sigma=E \cdot \varepsilon=E \frac{\delta l}{l o}
$$


no qual $\boldsymbol{E}$ é o módulo de Young. Seu valor é equivalente à inclinação da reta na região de deformação elástica.

Desta forma, conclui-se que o módulo de Young é um parâmetro mecânico que proporciona a medida de rigidez de um material sólido. Quanto mais duro é o material mais difícil é deformá-lo, ou seja, maior o seu módulo de elasticidade. Entretanto, ele também está relacionado a frequência natural da vibração da estrutura, a velocidade de propagação de ondas, entre outras características do material.

Assim como o comportamento do material pode depender da velocidade com que a carga é aplicada, o módulo elástico também pode sofrer variação dependendo da velocidade com que a carga é aplicada. Essa dependência é denominada viscoelasticidade. Desta forma, precisamos de métodos diferentes para mensurar tanto módulo elástico quase-estático, ou seja, em baixas taxas de deformação, quanto o módulo elástico dinâmico, em medias e altas taxas de deformação.

O método quase-estático consiste em aplicar carga no material em baixíssimas velocidades. $\mathrm{O}$ tipo de ensaio mais comum no regime quase-estático é o ensaio de tração e seu resultado mais tradicional é o diagrama de tensão deformação do material.

Dentro dos métodos dinâmicos existem testes experimentais específicos para cada faixa de taxa de deformação, definidas por: 1) médias taxas de deformação, como, por exemplo, as existentes tanto em impactos mecânicos originados ao derrubarmos objetos, quanto as sofridas pelos tendões em corridas; ii) altas taxas de deformação, como as existentes em colisões veiculares; iii) altíssimas taxas de deformação, como por exemplo em ondas de choque de explosões. Dentro dos métodos dinâmicos para médias taxas de deformação, podemos citar os ensaios cíclicos, como por exemplo a fadiga (Gere, 2009). 


\subsubsection{Tração}

O ensaio de tração permite que se avalie o comportamento do material sob carga de tração elástica lentamente aplicada. É aplicado um deslocamento na amostra, que se alonga, gerando uma força correspondente contraria ao movimento imposto. Podendo o alongamento e a força serem medidos, obtém-se uma curva de força em função deste alongamento. Ao se considerar as dimensões da amostra, pode-se calcular a tensão de engenharia e deformação de engenharia ou nominais correspondentes, definidas anteriormente. Desta forma, obtém-se a curva de tensão deformação para a amostra, que independente das dimensões, e representa então o comportamento do material sob tração. Informações referentes à resistência, rigidez e deformabilidade do material podem ser obtidas da curva tensão deformação.

O início do ensaio de tração é caracterizado por deformações elásticas, na qual é válida a lei de Hooke. Acima de uma determinada tensão, o regime de deformações muda de elástico para plástico. Esta tensão é determinada "tensão de escoamento" do material ou limite de escoamento $\left(\sigma_{y}\right)$. Alguns materiais tem uma tensão de escoamento bem definida. No caso da tensão de escoamento não estar bem definida na curva de tensão deformação, um valor arbitrário é determinado por normas, como para metas em geral no qual a tensão de escoamento é a tensão relativa à uma deformação de $0,2 \%\left(\sigma_{y} 0,2 \%\right)$.

Já no regime plástico, ou seja, em tensões maiores que a de escoamento, a deformação deixa de ser completamente reversível e uma parte da deformação total sofrida pela amostra se torna permanente. A essa deformação é dado o nome de deformação plástica. Em geral a curva tensão deformação na região plástica não é linear. À medida que o aumento da tensão vai ampliando a deformação plástica, a deformação elástica segue aumentando. No momento do rompimento, a tensão aplicada no material $\left(\sigma_{\mathrm{u}}\right)$ é denominada limite de resistência do material e é máxima tensão pela qual o material pode ser submetido antes de romper.

Ao decorrer do teste, algumas regiões se deformam mais que outras e ocorre uma diminuição na área da secção transversal localizada no ponto que se 
origina a ruptura. A região correspondente a esta deformação é denominada de pescoço ou estriç̧ão. Devido a esta diminuição na área, a carga para deformar o material, e consequentemente também a tensão nominal, diminuem, apesar da tensão real continuar constante ou subindo (Oréfice e col, 2012).

\subsubsection{Fadiga}

Em muitas aplicações, o componente ou implante é submetido a baixas tensões, porém repetidas, podendo estas tensões serem resultado de esforços de rotação, vibração, flexão, etc. Mesmo estando submetidos a tensões abaixo do limite de escoamento e consequentemente da tensão de ruptura, o material pode falhar depois de um grande número de ciclos de aplicação de esforço. Este modo de falha é conhecido como fadiga (Oréfice e col, 2012).

Pode-se até mesmo criar um paralelo com a fadiga muscular. Um dos primeiros trabalhos neste assunto foi escrito por Angelos Mosso em 1891, o qual fez diversos estudos sobre a fadiga, chamado La Fatica. Desde, então, sabe-se que a fadiga reduz a sensibilidade corporal como um todo, a sensibilidade muscular e representa um sinal sobre diminuição dos estoques de energia, quando há um aumento da ventilação para remover subprodutos do sangue (DI GIULIO e col., 2006). Outras definições para a fadiga encontradas na literatura estão descritas a seguir: "Decréscimo na performance" (Di Giulio e col., 2006); "Qualquer redução induzida pelo exercício na capacidade de gerar força ou potência" (Vollestad, 1997); "A fadiga pode ser definida como uma incapacidade de manutenção da força ou potência produzida" (Hawley e Reilly, 1997); "Diminuição da força na contração máxima sustentada" (Barry e Enoka, 2007).

\subsubsection{Máquina Universal de Ensaios - Instron}

A tensão em ensaios mecânicos é definida como força sobre unidade de área e pode ser classificada como: compressiva, que quando aplicada diminuí o tamanho do material; tensora, se aumentar o tamanho do material; ou de 
cisalhamento, quando promove o deslizamento de uma região do material em relação à outra (Kosmiskas, 2007).

O teste de tração consiste em um método para determinar o comportamento de materiais sob uma carga de estiramento axial. Os dados obtidos no teste são usados para determinar o limite elástico, alongamento, módulo de elasticidade, limite proporcional, redução na área, resistência à tração, ponto de estricção, resistência à estricção e outras propriedades de tração (Instron do Brasil, 2008).

Os ensaios de tração são executados em um equipamento denominado Máquina Universal de Ensaios Instron modelo 3339 (FIG. 2 A) e Instron modelo 5567 (FIG. 2 B), com célula de carga de $10 \mathrm{kN}$, com limite de velocidade de teste $400 \mathrm{~mm} / \mathrm{min}$ e $500 \mathrm{~mm} / \mathrm{min}$ respectivamente e um limite de frequência de aquisição dos resultados de $10 \mathrm{~Hz}$ (FIG.2). Esta máquina consiste basicamente de um arranjo constituído por duas travessas (uma fixa e outra móvel), uma célula de carga, um mecanismo de direcionamento, acessórios de fixação dos corpos de prova e extensômetros. Nos ensaios de tração, dispositivos de fixação dos corpos de prova (garras) são acoplados às travessas fixa e móvel e seu funcionamento baseia-se no movimento vertical das garras/prensas, as quais possuem velocidade de afastamento/aproximação, respectivamente, controladas pelo operador (Canto e Pessan, 2003).

Em muitas aplicações, o componente ou implante é submetido a tensões baixas, porém, de maneira repetitiva, podendo estas tensões serem resultado de esforço de rotação, vibração, flexão etc. Mesmo sob tensões abaixo do limite de escoamento, este material pode falhar após vários ciclos de aplicação de esforço, sendo esta falha conhecida como fadiga. Para avaliar a resistência a fadiga podem ser utilizados ensaios específicos (Oréfice, e col., 2006). 

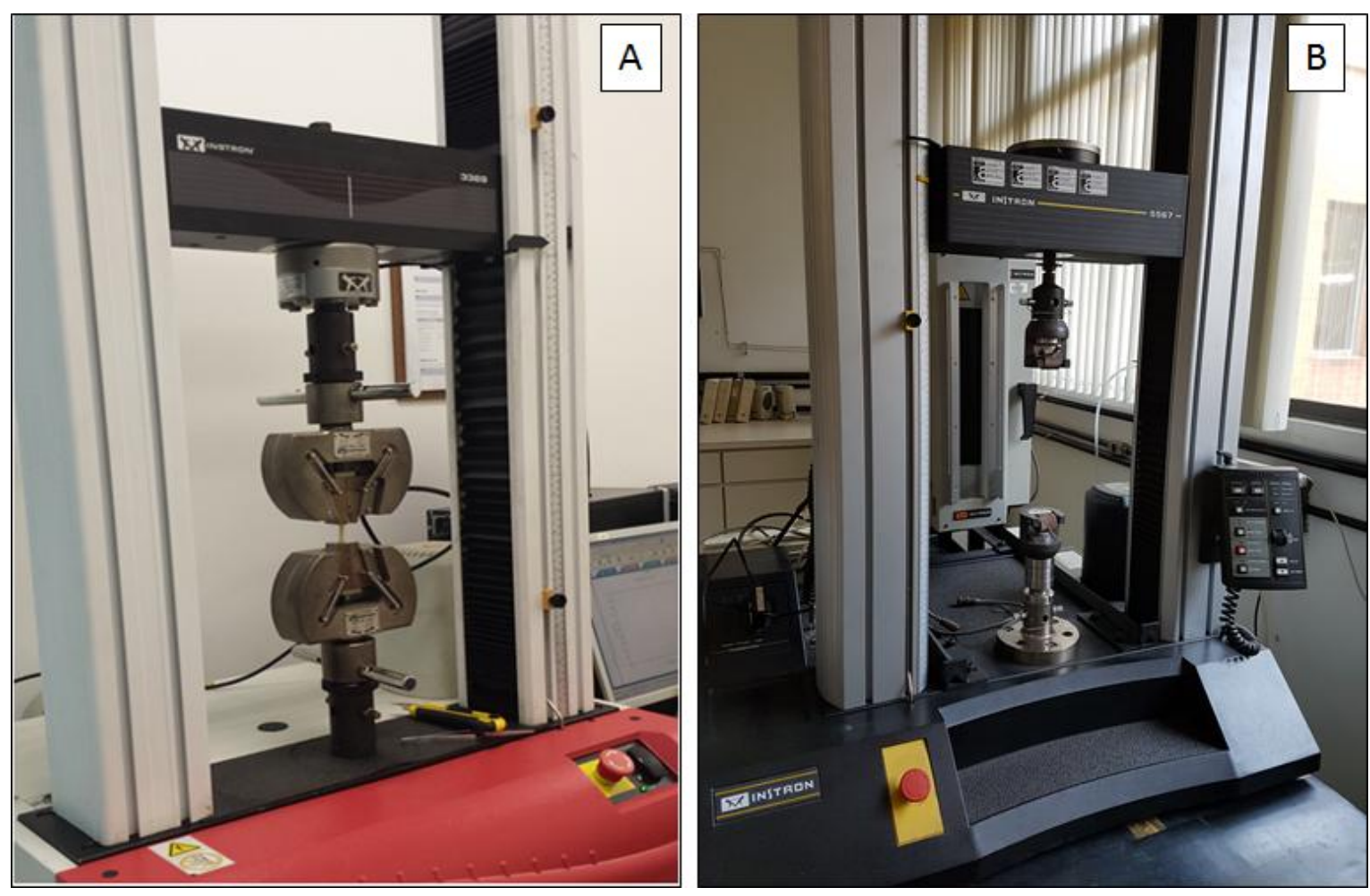

FIGURA 2. Máquina de ensaios Instron modelo 3369 e Instron modelo 5567. 


\section{MATERIAIS E MÉTODOS}

\subsection{Aprovação do comitê de ética}

Este projeto foi encaminhado ao comitê de ética por meio da Plataforma Brasil e aprovado sob o número CAAE 44669115.0.0000.0065 (anexo 1).

\subsection{Infraestrutura}

Os ensaios foram realizados no Centro de Tecnologia das Radiações (CTR) e Centro de Laser e Aplicações (CLA) localizados nas dependências do IPEN-CNEN/SP e no Departamento de Mecatrônica e Sistemas Mecânicos da Escola Politécnica da USP.

\subsection{Obtenção das amostras}

As amostras foram obtidas nos Bancos de Tecidos Musculoesquelético com a colaboração de duas instituições; Santa Casa de Misericórdia de São Paulo e Instituto de Traumatologia e Ortopedia do Hospital das Clínicas da Faculdade de Medicina de São Paulo.

Foram obtidas amostras de tendão fibular e tendão tibial, respeitando as normas da RDC no 220 (ANVISA, 2006) e a portaria no 2600 (SNT, 2009).

O processo de doação dos tecidos obtidos nesta pesquisa contempla o consentimento familiar livre e esclarecido por meio do termo de doação com a finalidade de investigação científica contendo a autorização previamente efetuada pelos bancos colaboradores.

\subsection{Amostras e processamento}

Tendões tibiais (amostra A) FIG. 3 A

Tendões fibulares (amostra B) FIG. 3 B 
As amostras foram previamente processadas pelos bancos de tecidos colaboradores, sendo o método $\mathrm{A}$ já pré-estabelecido e o $\mathrm{B}$ comunmente utilizado em processamento de ossos e servindo como teste em tecidos moles.
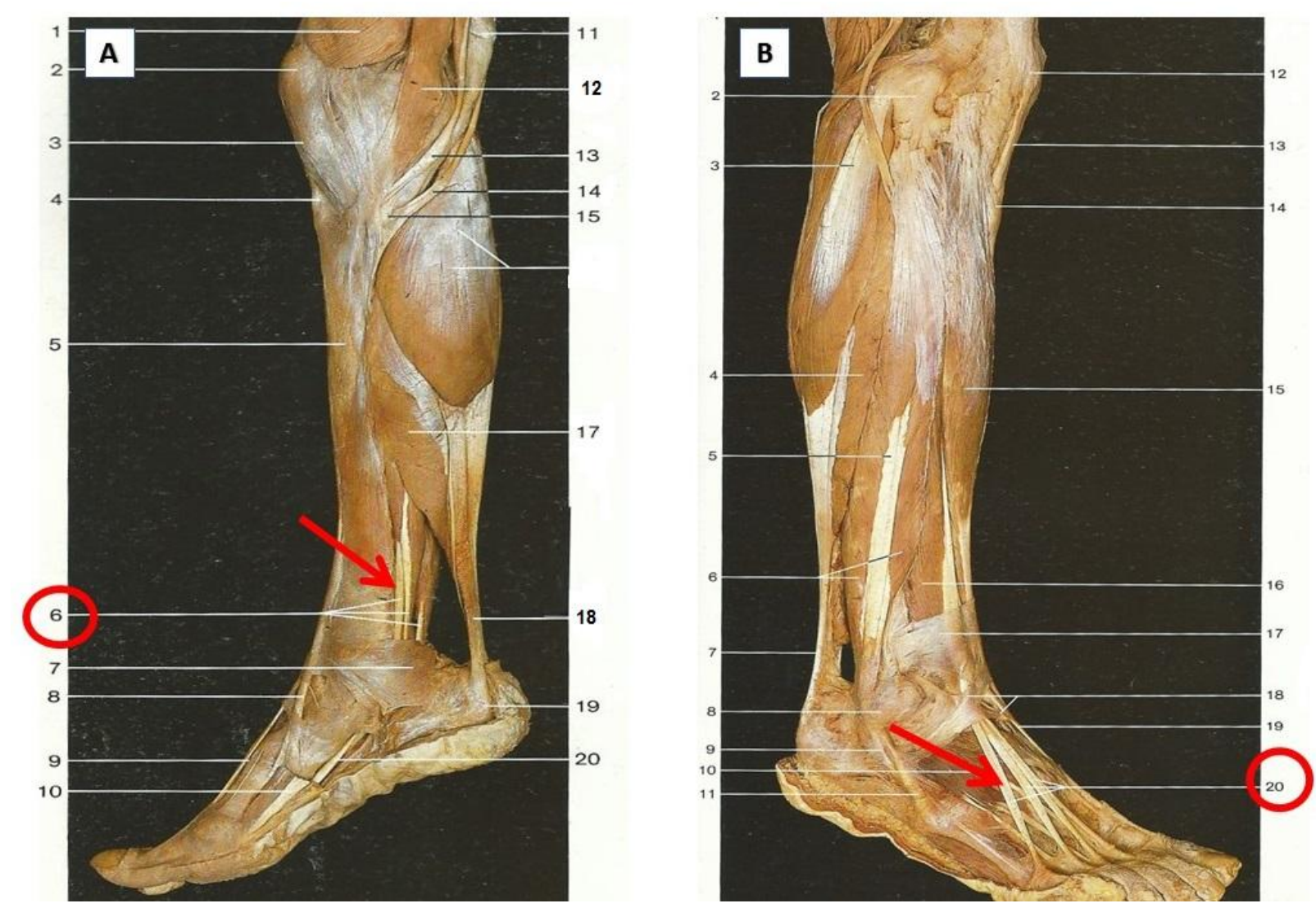

FIGURA 3. Localização anatômica dos tendões. Imagem A mostra o tendão tibial posterior e imagem B mostra o tendão fibular.

Fonte: Sobotta, 2012.

\subsubsection{Processamento A}

Após a captação dos tecidos, foi realizada a limpeza do mesmo, efetuando a retirada dos músculos aderidos e outras partes moles do tendão, com o auxílio de um formão reto ou rugina e bisturi. Estando previamente limpos os tendões foram imersos em um litro de soro fisiológico $0,9 \%$ por 15 minutos e logo após imersos em uma solução de álcool 70\% por 15 minutos. E por último os tendões foram imersos em um litro de solução contendo antibiótico $(500 \mathrm{mg}$ de Vancomicina por litro de soro fisiológico). Então foi realizada a coleta de material 
para análise microbiana (swab de cada tecido) e coleta de material para "bioburden" (carga microbiana) do último líquido em contato com o tecido.

Ao termino dos processamentos o tecido foi colocado em uma embalagem de plástico esterilizado, selado a vácuo e armazenado em freezer $-80^{\circ} \mathrm{C}$.

\subsubsection{Processamento B}

Após a captação dos tecidos, estes passaram por um processo de limpeza, efetuando a retirada dos músculos aderidos e outras partes moles do tendão.

Logo após a limpeza, o tecido foi colocado no ultrassom juntamente com uma solução de peróxido de hidrogênio a 3\%, por um ciclo de 200 a 300 segundos.

Após o processamento, o tecido foi embalado a vácuo em sacos plásticos esterilizados e armazenado em freezer $-80^{\circ} \mathrm{C}$.

\subsubsection{Separação dos Grupos}

As amostras foram separadas de acordo com o processamento recebido, $\mathrm{e}$ por lote, tendo cada um o seu respectivo controle.

\subsubsection{Identificação das amostras}

As amostras foram identificadas de acordo com o banco colaborador, processamento recebido e dose de irradiação aplicada sendo 0 (controle); 12,5; 15 e 25 kGy.

\subsubsection{Acondicionamento das Amostras}

As amostras foram acondicionadas em caixas térmicas revestidas com papelão, separadas por dose, sendo o material acomodado na face da caixa mais 
próxima da fonte e completando o restante do espaço com gelo seco, para evitar variação da temperatura.

\subsection{Irradiação das amostras}

O processo de irradiação das amostras foi realizado no Centro de Tecnologia das Radiações (CTR) do Instituto de Pesquisas Energéticas e Nucleares (IPEN - CNEN SP). As amostras dos diferentes grupos foram irradiadas, utilizando fontes de ${ }^{60} \mathrm{Co}$ do Irradiador Multipropósito tipo compacto (FIG. 4) e receberam doses efetivas de 12,6 kGy, 14,6 kGy e 23,9 kGy, correspondendo às doses nominais de 12,5 kGy, 15 kGy e 25 kGy (Quadro 1). As amostras do controle foram mantidas nas mesmas condições, porém, não foram irradiadas como pode-se observar abaixo na (FIG. 5).
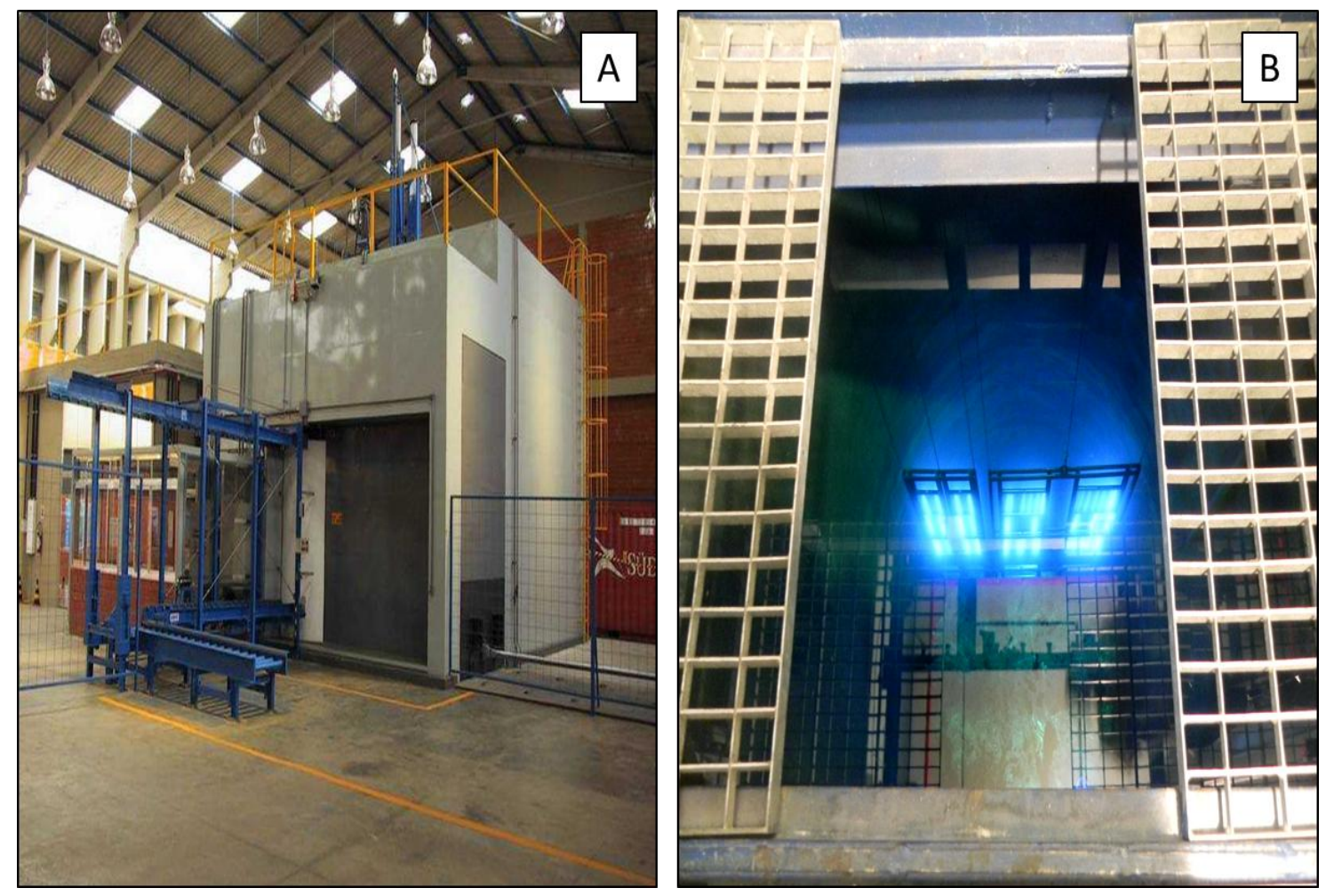

FIGURA 4. Foto do irradiador multipropósito localizado no Centro de Tecnologia das Radiações/IPEN, parte externa (A) e parte interna (B). 
QUADRO 1 - Irradiação das amostras

\begin{tabular}{|cc|}
\hline Dose Nominal (kGy) & Dose Medida (kGy) \\
\hline 12,5 & 12,6 \\
\hline 15 & 14,6 \\
\hline 25 & 23,9 \\
\hline
\end{tabular}

Taxa de dose: $4,2 \mathrm{kGy} \cdot \mathrm{h}^{-1}$
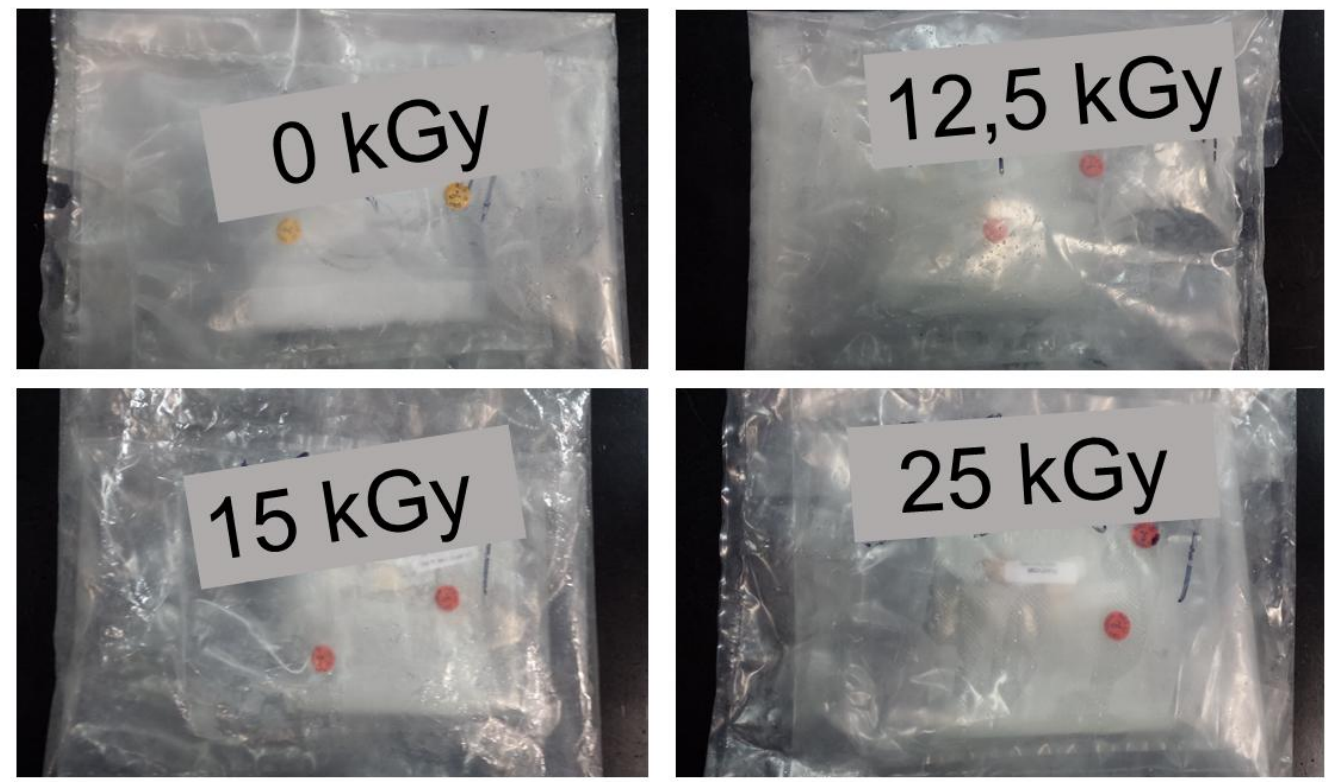

FIGURA 5. Amostras irradiadas nas doses de 12,5, 15 e $25 \mathrm{kGy}$ como mostra a etiqueta go/no go de controle, na coloração vermelha indicando que as amostras foram irradiadas e $0 \mathrm{kGy}$ (controle) com a etiqueta amarela indicando que a amostra não passou pelo processo de irradiação.

\subsection{Avaliação Macroscópica}

As amostras passaram por uma avaliação visual antes e após o processo de irradiação dos tecidos. Onde foi analisada a estrutura dos tecidos em busca de possíveis alterações que possam ter ocorrido por influência do tipo de processamento das amostras. 


\subsection{Analises Ópticas}

As análises ópticas foram realizadas no Centro de Laser e aplicações CLA/IPEN, com a colaboração do Prof. Dr. Anderson Zanardi de Freitas.

\subsubsection{Tomografia de Coerência Óptica (OCT)}

O sistema OCT 1300 SS utiliza como fonte óptica um LED Superluminecente (SLD), com uma largura espectral de $100 \pm 5 \mathrm{~nm}$ e centrado em $930 \mathrm{~nm}$, com potência de $2 \mathrm{~mW}$ na amostra (de 0,5 mm largura por 0,4 mm comprimento). As imagens com uma resolução lateral de 6,0 microns e longitudinal de 4.1 microns foram geradas pelo deslocamento do ponto de incidência na amostra por espelhos acoplados a um galvanômetro. A luz foi focalizada na amostra com uma lente de $5 \mathrm{~cm}$ de distância focal. Os dados obtidos e armazenados em microcomputador (OCP930SR Thorlabs Inc. NJ, USA). Foram obtidas duas imagens, uma de cada um dos métodos para mostrar a estrutura das amostras.

\subsubsection{Análise de Tomografia de Coerência Óptica Sensível à Polarização (PS-OCT)}

O equipamento de OCT possui um módulo de polarização PS-OCT 1300, que é utilizado para o ensaio de Tomografia de Coerência Óptica sensível à polarização, este possui um comprimento de onda centrado em 1325 nm com 10 $\mathrm{mW}$ de potência na amostra, das quais foram obtidas imagens em ângulo de incidência de luz aproximadamente $45^{\circ}$ em relação ao longo do eixo. As imagens feitas no PS-OCT, destacando as áreas birrefringentes podem fornecer medidas quantitativas de birrefringência e profundidade de penetração de luz, que são variáveis contínuas medidas nos níveis de razão (Bagnaninchi e col., 2010). As imagens foram obtidas e armazenadas em microcomputador (OCP930SR Thorlabs Inc. NJ, USA). Foram obtidas 64 imagens do método $A$, sendo 32 
imagens do tecido não irradiado e 32 do mesmo tecido após a irradiação e do método $B$ foram 72 imagens, 36 do tecido não irradiado e 36 após irradiação.

\subsubsection{Análise de dados obtidos por PS-OCT}

Para a análise estatística da diferença de distâncias entre as áreas birrefringentes foram realizadas 40 medições utilizando o software ImageJ (FIG. 6) em cada uma das 136 imagens obtidas. Os valores das médias foram submetidos à análise de variância unifatorial (ANOVA). Para todas as variáveis foram calculadas medidas de estatística descritiva, como média, mediana, desvio padrão e intervalo interquartílico normalizado (IQN), com o objetivo de verificar se havia uma diferença estatisticamente significativa $(p<0,05)$ entre o controle e as amostras irradiadas. Quando foram constatadas diferenças, ou seja, $p<0,05,0$ teste de Tukey foi aplicado para a comparação das médias. Para as análises inferenciais foi considerado um valor $\alpha=5 \%$ para rejeição da hipótese de nulidade (Granato e col., 2014). Para as análises estatísticas foi empregado o software GraphPad Prism 5.

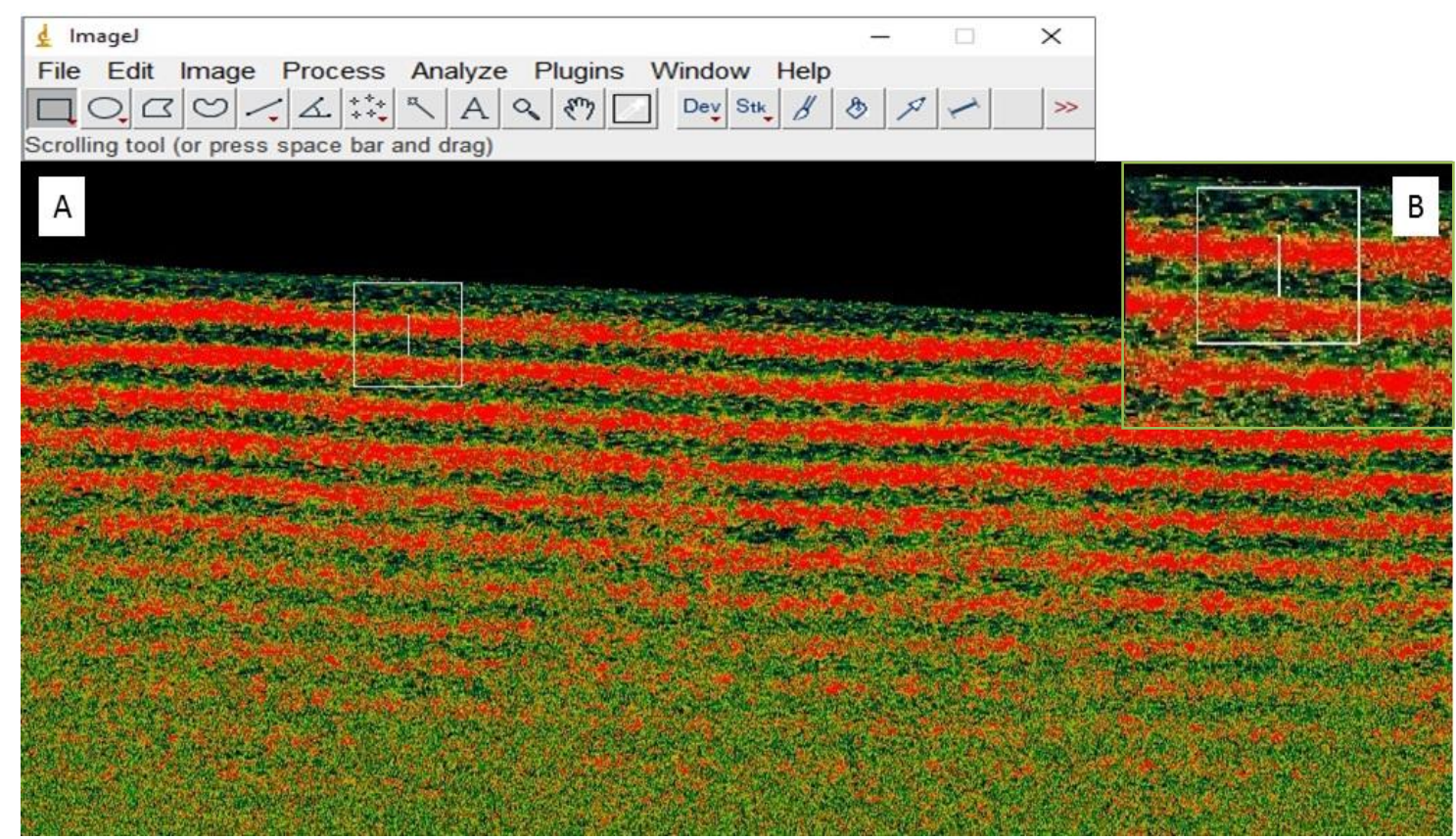

FIGURA 6. Imagem A medida realizada com auxílio do software ImageJ sendo um total de 40 medidas por imagem, imagem B (sobreposta no canto superior direito) medida realizada, visualização em aumento de $300 \%$. 


\subsection{Histologia}

As amostras foram processadas pelo laboratório de técnicas histológicas do Instituto de Ciências Biomédicas (ICB USP/SP).

\subsubsection{Processamento das amostras para histologia}

As amostras de tendão foram imersas em uma solução de formol tamponado a 10\% para serem fixadas. Após 48 horas, esses tecidos foram transferidos para álcool $70 \%$. Esta solução foi renovada periodicamente, conforme a eliminação dos resíduos de fixador. Os tecidos foram imersos em soluções de álcool crescente $50 \%$ à absoluto até a completa desidratação das peças, e posteriormente foram diafanizados em xilol em temperatura ambiente.

As peças foram colocadas em parafina, em seguida, foram realizados os cortes com $5 \mu \mathrm{m}$ de espessura em micrótomo Leica RM2255 (Leica Microsystens, Welzar, Alemanha) e corados com hematoxilina-eosina (HE) e Picrosirius.

\subsection{Teste biomecânico}

Os testes biomecânicos foram realizados no Departamento de Engenharia Mecatrônica e Sistemas Mecânicos da Escola Politécnica da USP, com a colaboração do Prof. Dr. Rafael Traldi Moura.

Os dados obtidos por meio dos testes mecânicos nos equipamentos Instron 3339 e Instron 5567 foram processados tanto no Excel quanto no Matlab, no qual foram gerados gráficos dos resultados obtidos tanto para o teste de tração.

\subsubsection{Tipos de Corpo de Prova}

Para realização dos testes mecânicos foram utilizados oito tipos de corpo de prova como especificado na TAB.1, estes foram separados de acordo com o método de processamento e a dose com que o mesmo foi irradiado denominado no Quadro 2 como rad 0, 1, 2 e 3, fazendo referência ao controle, 12,5 kGy, 15 
kGy e 25 kGy respectivamente. Para cada um dos 8 tipos foram realizados 5 testes redundantes. Cada teste possuía uma numeração única presente no Quadro 2.

QUADRO 2 - Dados das amostras

\begin{tabular}{|c|cccc|}
\hline Método & 0 & 1 & 2 & 3 \\
\hline A & $1-5$ & $11-15$ & $21-25$ & $31-35$ \\
\hline B & $6-10$ & $16-20$ & $26-30$ & $36-40$ \\
\hline
\end{tabular}

\subsubsection{Dimensões do Corpo de Prova}

Os corpos de prova para realização dos testes mecânicos foram cortados com $50 \mathrm{~mm}$ de comprimento.

As larguras e espessuras variaram conforme as dimensões de cada tendão. Desta forma, para o cálculo da área dos corpos de prova, primeiramente foi analisada a forma de cada uma das amostras. Determinava-se se o material apresentava secção transversal mais retangular, ovalada ou circular, conforme figura FIG. 7. Depois as medidas características eram obtidas com paquímetro. Por fim, a área da amostra era calculada.
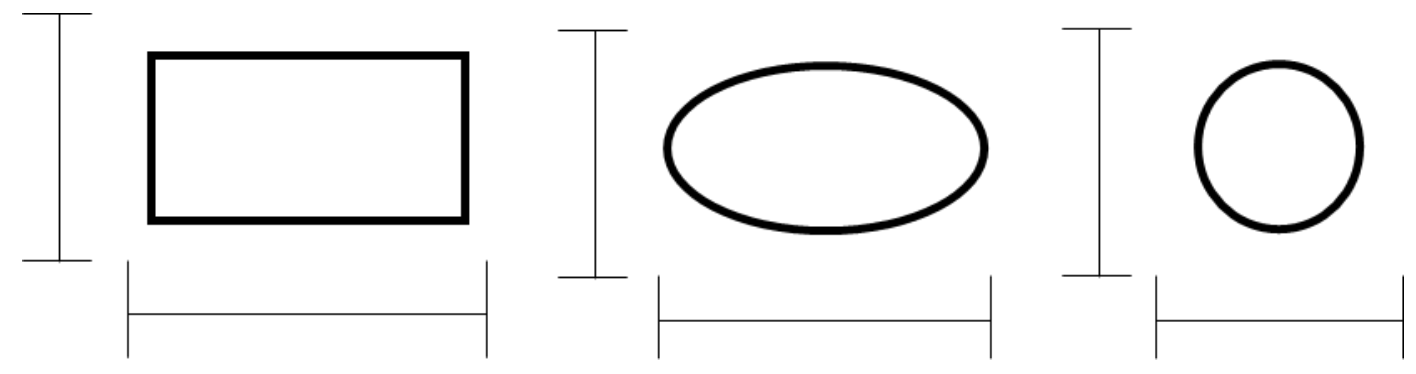

Figura 7. Especificação das medidas de área, as medidas utilizadas para medição da área de cada cp foram medidas a espessura e comprimento. 
A área medida de cada um dos 40 corpos de prova (CP), estão apresentados na tabela TAB. 1.

TABELA 1 Medida de área das amostras

\begin{tabular}{|c|c|c|c|c|c|c|c|c|}
\hline \multirow[b]{2}{*}{ CP } & \multicolumn{2}{|c|}{ Controle } & \multicolumn{2}{|c|}{$12,5 \mathrm{kGy}$} & \multicolumn{2}{|c|}{15 kGy } & \multicolumn{2}{|c|}{$25 \mathrm{kGy}$} \\
\hline & 1 (A0) & 2 (BO) & 3 (A1) & 4 (B1) & 5 (A2) & 6 (B2) & 7 (A3) & 8 (B3) \\
\hline \multirow{5}{*}{ Área $\left(\mathrm{mm}^{2}\right)$. } & 3,48 & 4,98 & 7,24 & 6,91 & 5,64 & 3,89 & 6,64 & 5,4 \\
\hline & 6,57 & 10,24 & 6 & 6,99 & 3,73 & 7,96 & 3,56 & 4,94 \\
\hline & 10,25 & 5,05 & 8,45 & 4,52 & 6,89 & 3,71 & 5,82 & 4,13 \\
\hline & 5,03 & 3,34 & 7,49 & 7,38 & 5,66 & 4,81 & 4,13 & 4,59 \\
\hline & 4,71 & 3,42 & 8,71 & 4,76 & 2,74 & 3,97 & 7,04 & 3,75 \\
\hline
\end{tabular}

\subsubsection{Fixação da Amostra}

$\mathrm{Na}$ metodologia utilizada por Albert (2003) foi descrita uma garra para manter a temperatura baixa conforme FIG.8A, com cunhas anexas a garra para 0 deposito de gelo seco. Entretanto as amostras foram fixadas a temperatura ambiente para que se mantivesse o mais próximo possível da temperatura corporal. Devido a redução da rigidez mecânica comparando-se a temperatura utilizada por Albert, foi necessária a realização de ao menos 30 testes com diferentes forças aplicadas nas cunhas das garras ilustradas na FIG.8B, em prol de se determinar uma força suficiente para não ocorrer deslizamento entre amostra e cunha, mas ainda assim minimizar uma estricção local e consequente concentrador de tensões, que poderia interferir nos resultados. 

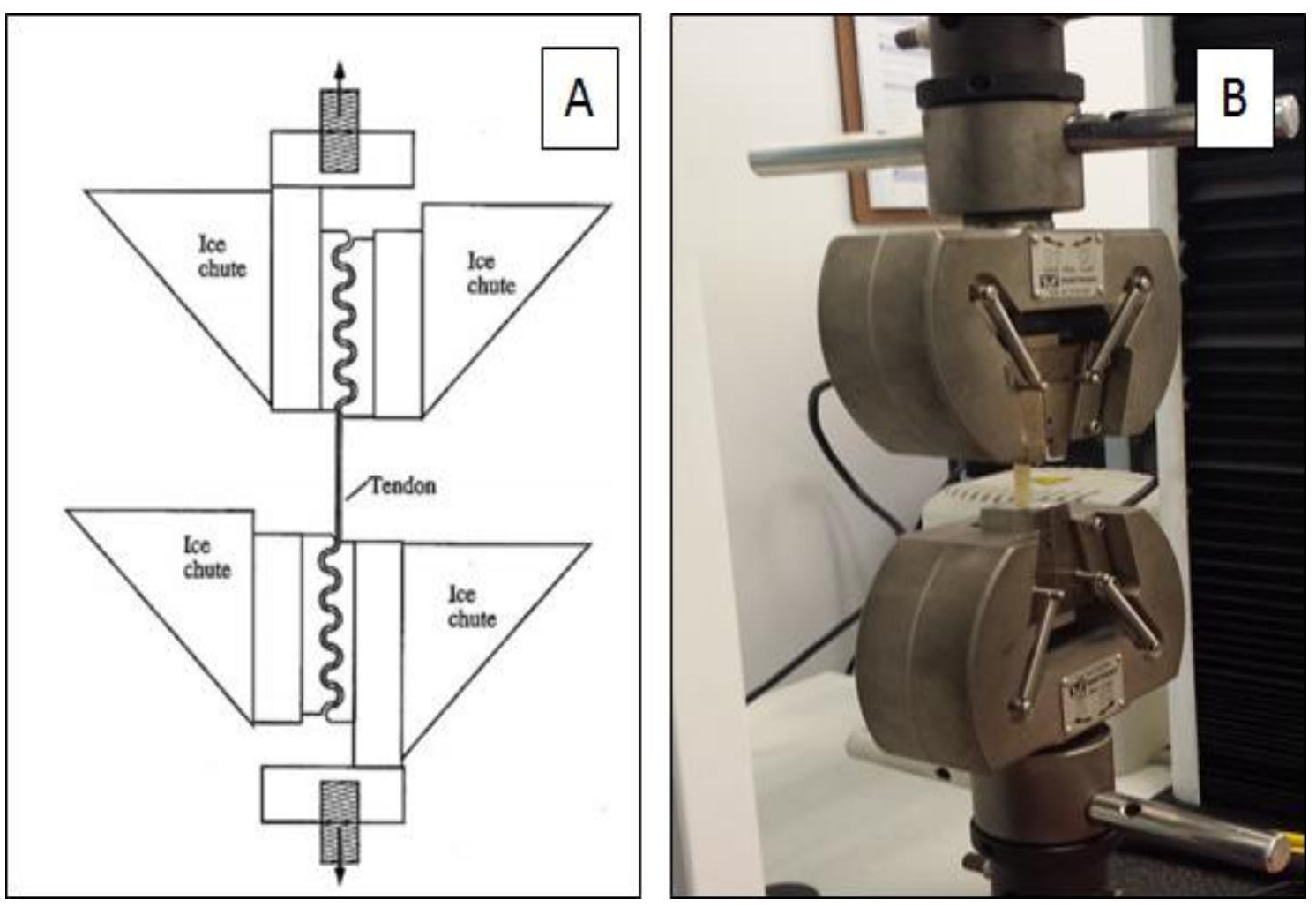

FIGURA 8. Garra (A) utilizada resfriar a amostra para fixação, garra (B) foi utilizada na realização dos testes.

\subsubsection{Tração}

\subsubsection{Teste de tensão-deformação}

Foi realizado um primeiro ensaio de tração para avaliar o comportamento da amostra. A amostra foi posicionada no equipamento e aplicada uma velocidade constante de $1 \mathrm{~mm} / \mathrm{s}$ até o rompimento da amostra.

O teste de tensão-deformação foi adaptado a partir dos artigos Schechtman (1997) e Andarawis-Puri (2012): na primeira parte da análise foi realizado um teste cíclico, abrangendo três diferentes taxas de deformação, seguido por um teste monotônico. Estes dois testes são usados para caracterizar as propriedades mecânicas dos materiais por meio de gráficos semelhantes aos testes da FIG. 9. 

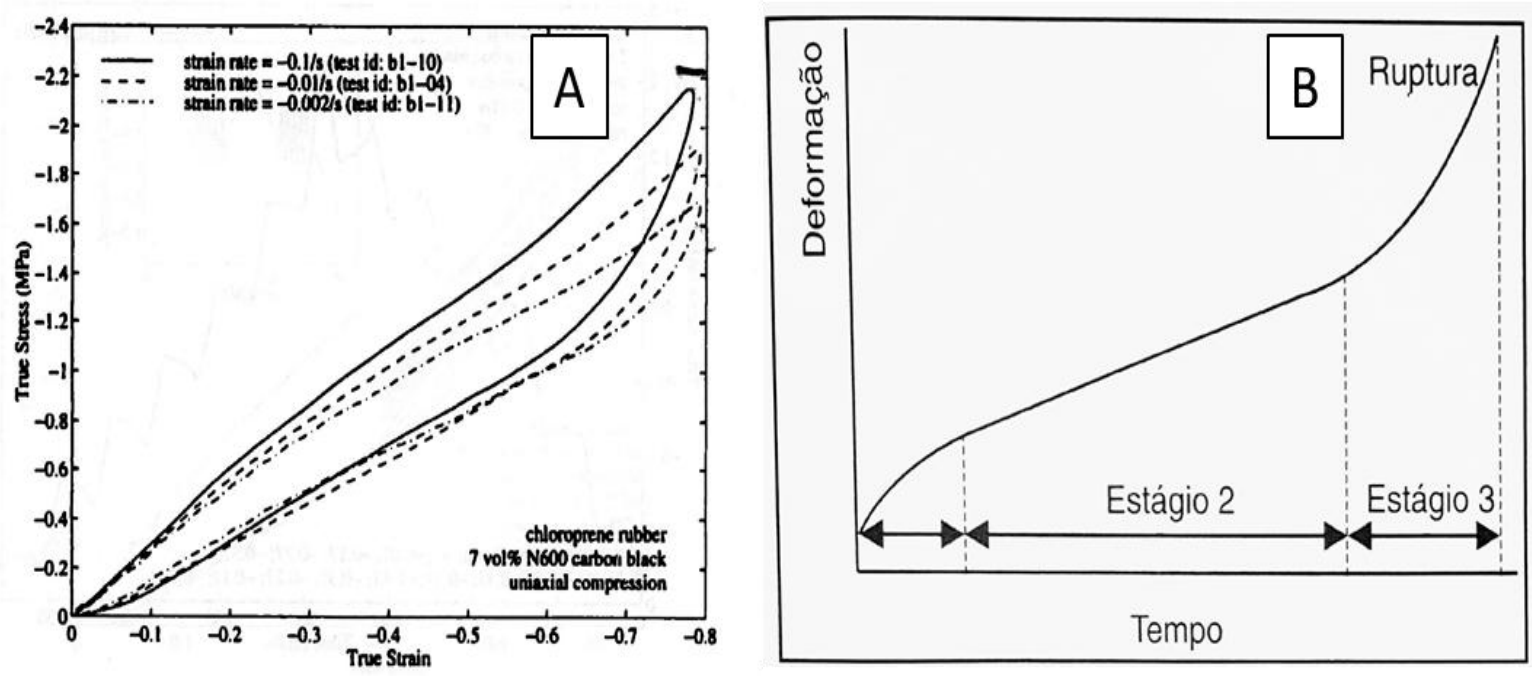

FIGURA 9. Gráficos de avaliação de comportamento de amostras, imagem A mostra o efeito de diferentes taxas de deformação e a imagem B mostra taxa de deformação no tempo até a ruptura da amostra.

Fonte: Bergström, 1999 e Oréfice 2012.

O teste realizado possuía cinco partes distintas denominadas pela numeração 1, 2, 3, 4, e 5. A parte 1 corresponde ao carregamento inicial no qual as cunhas das garras de fixação se locomovem, interferindo numa possível análise do módulo elástico. Na parte 10 corpo de prova é tracionado em uma velocidade de $1 \mathrm{~mm} / \mathrm{s}$ até $25 \%$ da tensão de ruptura determinada num primeiro ensaio de tração monotônico. A parte 1 é então finalizada com 0 descarregamento do corpo de prova até $5 \%$ da tensão máxima. As partes 2, 3 e 4 correspondem aos testes cíclicos realizados em três diferentes velocidades (1, 5 e $10 \mathrm{~mm} / \mathrm{seg}$ ). Na parte 5 e final do teste, a amostra foi tensionada até que perdesse por completo sua rigidez mecânica, ou seja, até ter sua tensão reduzida para $5 \%$ da tensão máxima, independente da deformação estar aumentando. Para cada um dos testes cíclicos foram realizados cálculos para determinar valores máximo e mínimo de carga específica utilizada para cada uma delas, como mostrado nas tabelas (TAB. 4, 5, 6 e 7 do item 5.3.3). 


\section{RESULtADOS}

\subsection{Análise macroscópica e Tomografia de Coerência Óptica (OCT)}

Com a análise macroscópica foi possível fazer uma primeira avaliação dos métodos utilizados para esterilização dos tecidos, observando claras diferenças entre os métodos $A$ e $B$.

As amostras foram analisadas no Centro de Lasers e Aplicações do Instituto de Pesquisas Energéticas e Nucleares.

O OCT foi utilizado para avaliar a morfologia dos tecidos. Por meio desta técnica foi possível obter imagens transversais dos tecidos utilizando luz pulsada penetrando o tecido sem causar danos ao material, podendo-se assim avaliar diretamente sua morfologia.

Pode-se observar na amostra A (método A) (FIG. 10A) que o tecido se encontra integro sem alterações aparentes em sua estrutura e na (FIG. 10B) temos a imagem processada por OCT, podendo assim constatar que o método $\mathrm{A}$ não causou modificações às características do tecido.

Porém, o tecido processado pelo método B (FIG. 10C) apresentou alterações em suas estruturas perdendo completamente suas características e apresentando bolhas internalizadas aparentes, que podem ser melhor observadas na imagem do OCT (FIG. 10D), confirmando a falta de homogeneidade do tecido. 

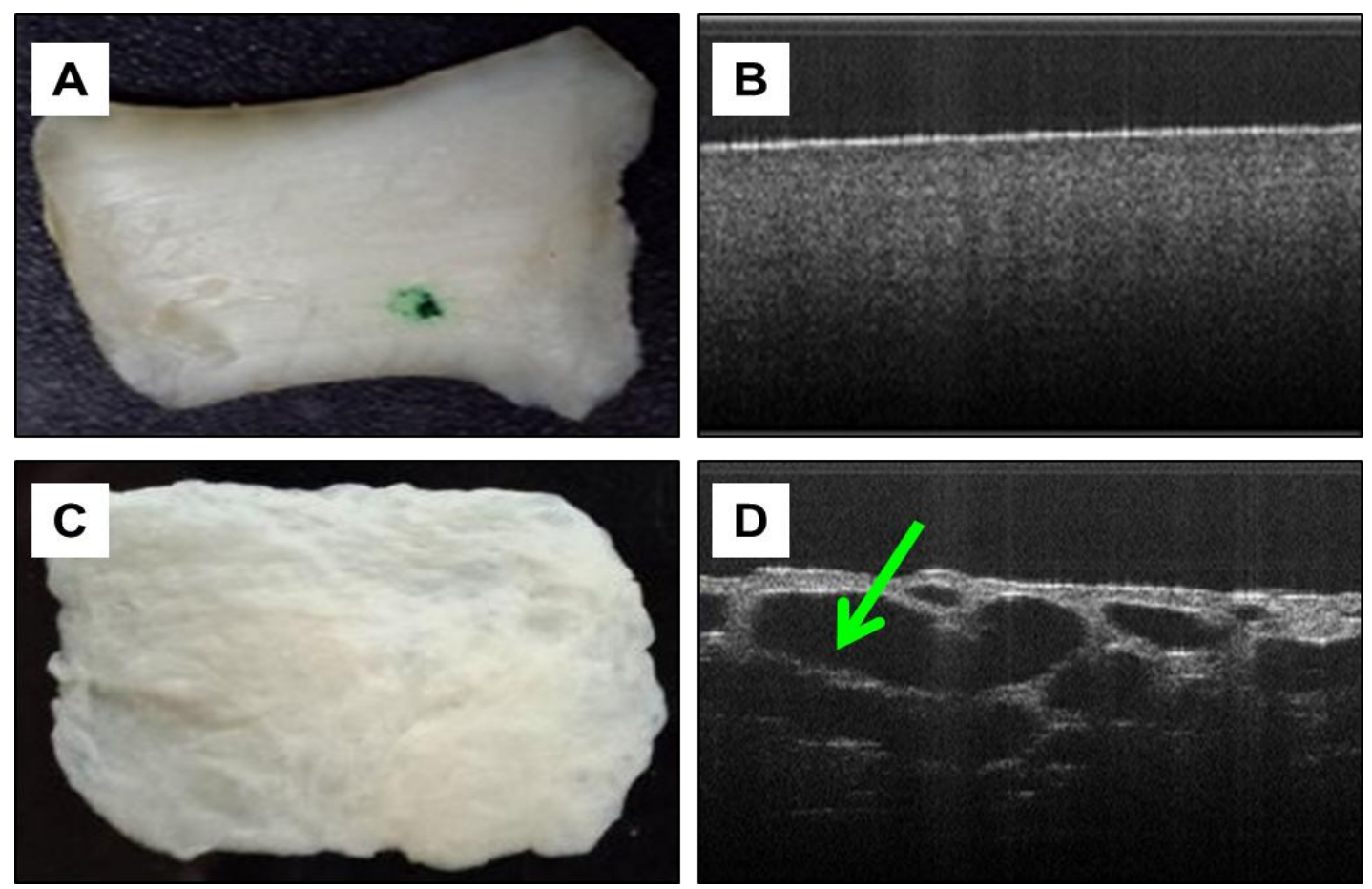

FIGURA 10. Imagem $A$ amostra processada pelo método $A$, o tecido esta integro sem alterações na sua estrutura, na imagem B o tecido processado em OCT, não apresentou variações na densidade e estrutura. Na imagem C a amostra processada pelo método $B$, macroscopicamente é possível observar que o tecido sofreu alterações na sua estrutura, imagem $D$ do tecido observado em OCT é possível observar alterações (buracos) estruturais na amostra.

\subsection{Análise de Tomografia de Coerência Óptica Sensível à Polarização (PS-OCT)}

A análise por meio de PS-OCT foi utilizada para avaliar a orientação das fibras colágenas, que podem ser identificadas nas áreas polarizadas das imagens mostradas na FIG. 11.

Foi possível observar que os tecidos processados pelo método A na FIG. 11 (Amostras A) apresentaram homogeneidade na sua estrutura, com várias bandas de birrefringência no material, mostrando a orientação das fibras colágenas, tanto antes da irradiação quanto após. 


\section{Amostras - A}

\section{Controles não irradiados}
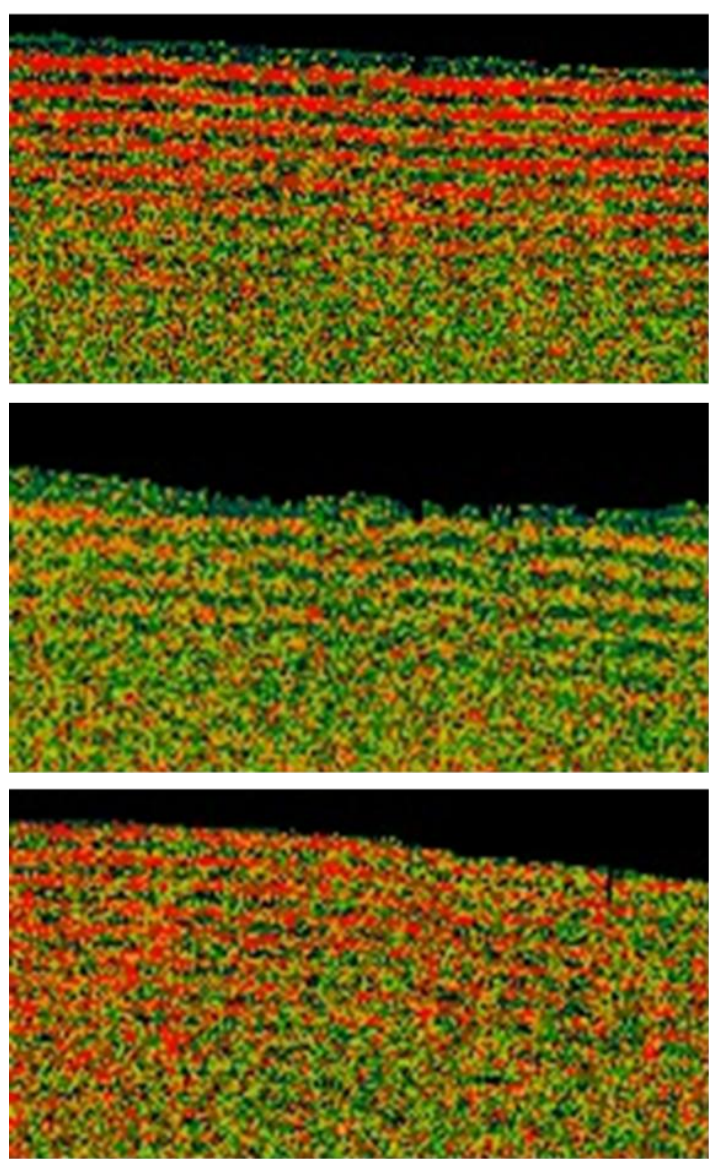

\section{Tecidos irradiados}
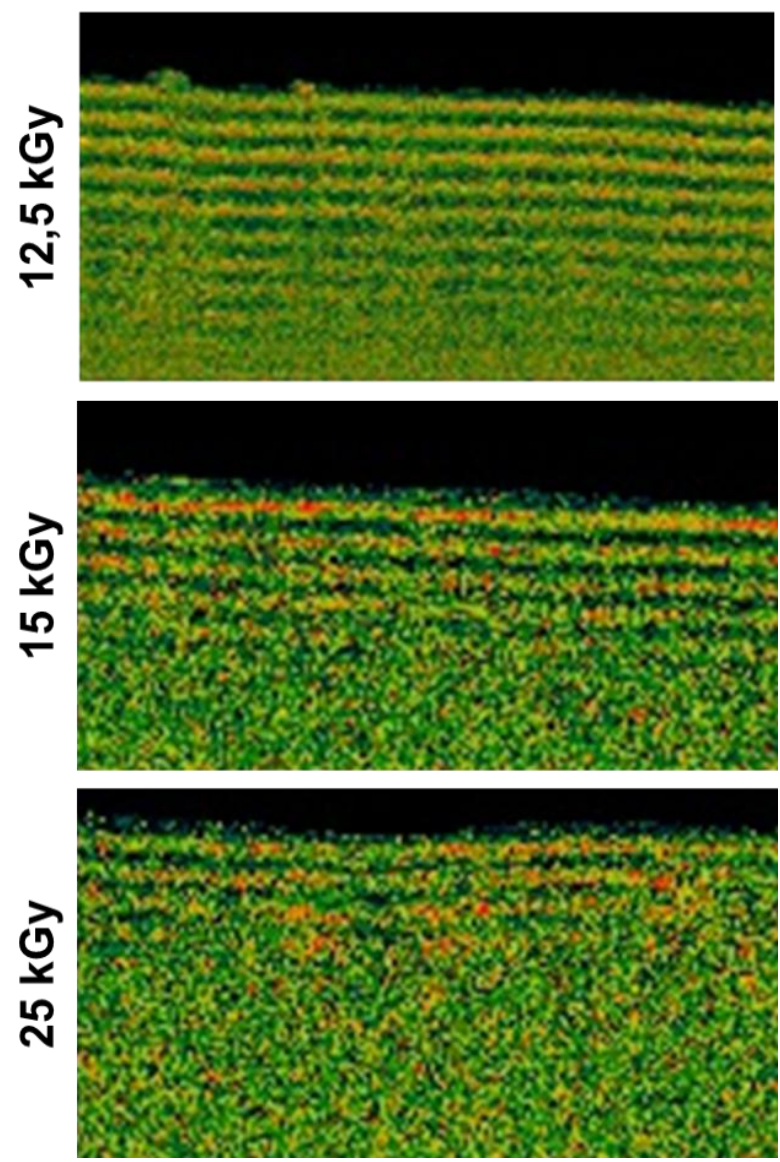

FIGURA 11. Imagens obtidas por PS-OCT amostra A processada pelo método A

Nas amostras processadas pelo método B na FIG. 11 foram observadas alterações nas imagens do material, não havendo uma homogeneidade na sua estrutura, mas sendo possível visualizar algumas áreas birrefringentes nas amostras antes e após a irradiação do material com as respectivas doses 12,5 kGy, 15 kGy e 25 kGy.

Podendo observar nas imagens o retardo de fase apresentado pelas amostras não irradiadas e irradiadas mostrando a orientação das fibras colágenas presentes também após o processo de irradiação das amostras. 


\section{Amostras - B}

Controles não irradiados
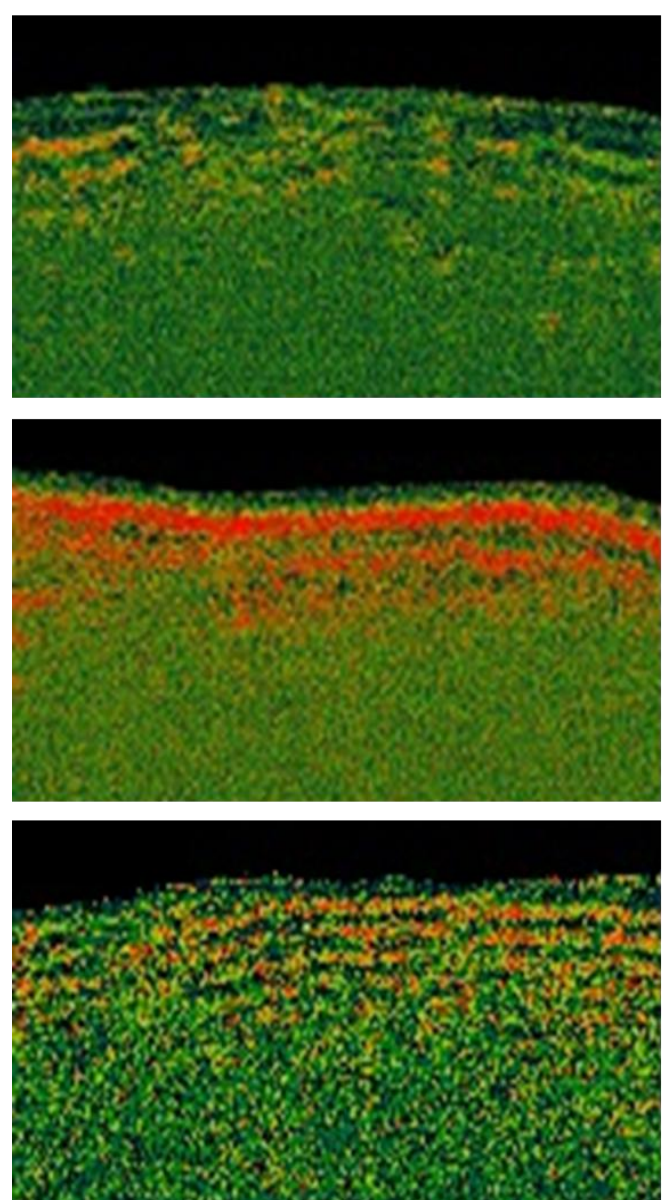

Tecidos irradiados
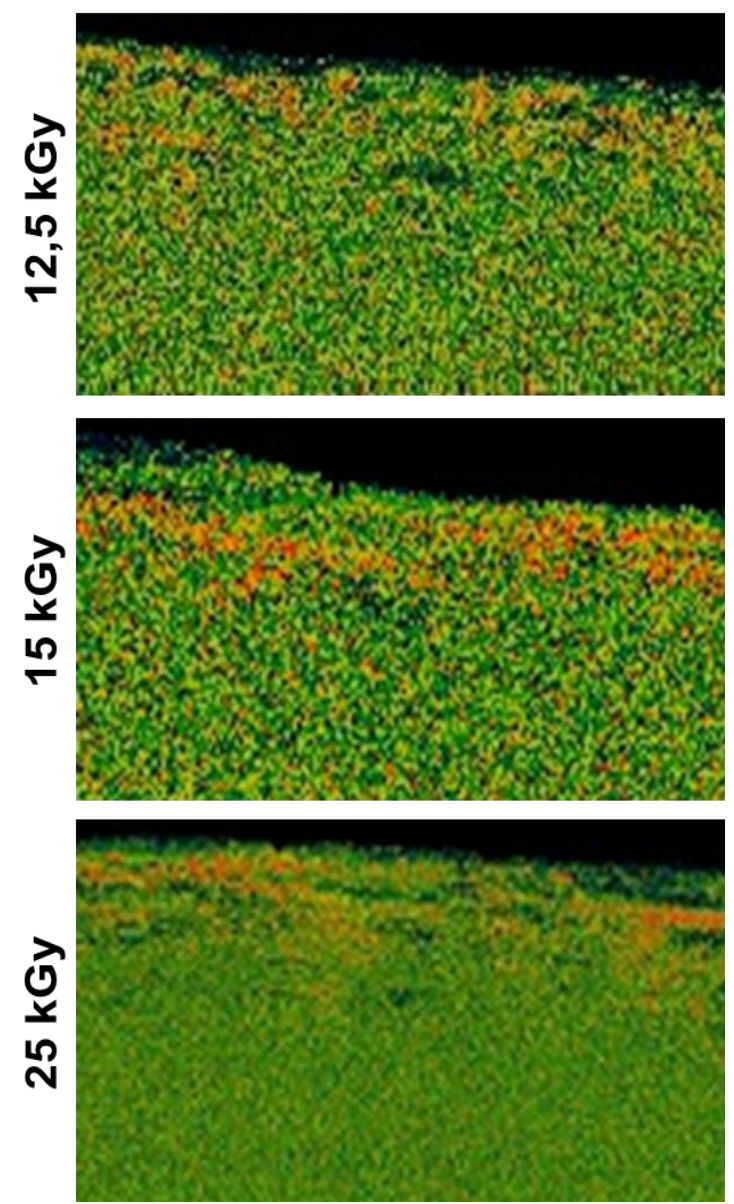

FIGURA 12. Imagens obtidas por PS-OCT amostra B processadas pelo método $B$.

Em ambas as formas de preservação e em todas as doses de radiação pode-se verificar o retardo de fase que mostra a presença de birrefringência, neste caso o colágeno.

$\mathrm{Na}$ imagem de birrefringência do método A é possível observar as bandas das fibras tanto no controle não irradiado quanto na amostra irradiada, o que não se observa nas amostras do método $B$ onde a nitidez é muito inferior tanto na imagem do controle não irradiado quanto nas irradiadas. 


\subsubsection{Análise estatistica do dados}

A partir dos dados obtidos (TAB. 2) foram feitas as análises estatísticas de cada grupo de tendão (irradiado vs não irradiado) FIG. 13.

TABELA 2 - Comparação das médias das distâncias entre as bandas de birrefringência grupo controle e grupo irradiado

\begin{tabular}{|c|c|c|c|c|}
\hline Amostra & $\begin{array}{c}\text { Grupo controle } \\
0 \mathrm{kGy}\end{array}$ & $\begin{array}{l}\text { Grupo } \\
\text { 12,5 kGy }\end{array}$ & $\begin{array}{l}\text { Grupo } \\
15 \text { kGy }\end{array}$ & $\begin{array}{l}\text { Grupo } \\
25 \text { kGy }\end{array}$ \\
\hline A01 & $155,1 \pm 0,89$ & $167,6 \pm 0,55$ & $165,8 \pm 0,97$ & $163,8 \pm 0,89$ \\
\hline $\mathrm{A} 02$ & $157,0 \pm 1,03$ & $169,9 \pm 0,79$ & $166,9 \pm 0,79$ & $162,0 \pm 0,90$ \\
\hline $\mathrm{A} 03$ & $153,3 \pm 1,44$ & $167,4 \pm 0,76$ & $162,0 \pm 0,74$ & $151,2 \pm 0,87$ \\
\hline A04 & $151,0 \pm 0,80$ & $161,3 \pm 0,98$ & $157,3 \pm 1,00$ & $150,7 \pm 1,00$ \\
\hline A05 & $168,6 \pm 0,71$ & $169,2 \pm 0,84$ & $166,4 \pm 0,93$ & $157,2 \pm 0,94$ \\
\hline A06 & $157,3 \pm 0,95$ & $155,0 \pm 1,24$ & $151,8 \pm 1,26$ & $146,8 \pm 0,76$ \\
\hline A07 & $159,5 \pm 0,85$ & $169,9 \pm 1,45$ & $154,8 \pm 1,45$ & $149,3 \pm 1,58$ \\
\hline A08 & $144,7 \pm 0,64$ & $165,8 \pm 0,76$ & $163,6 \pm 0,76$ & $161,4 \pm 0,84$ \\
\hline
\end{tabular}

Valores representam a média \pm desvio padrão. Significância estatística com ANOVA p<0,05.

Pode-se observar o resultado das análises de variância unifatorial (ANOVA), controle versos grupo irradiado. $O$ teste de Tukey foi aplicado para mostrar a homogeneidade entre os valores das médias. 


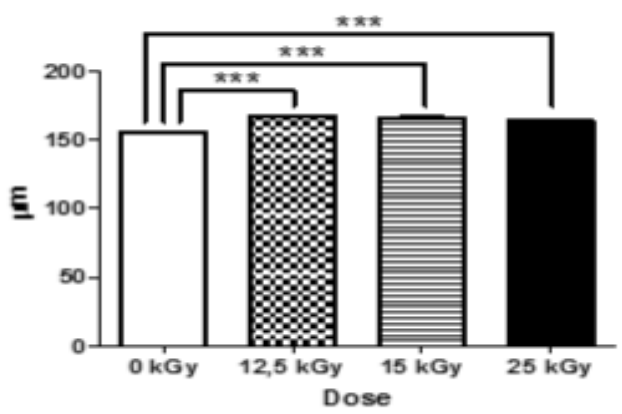

Amostra $\mathrm{A03}$

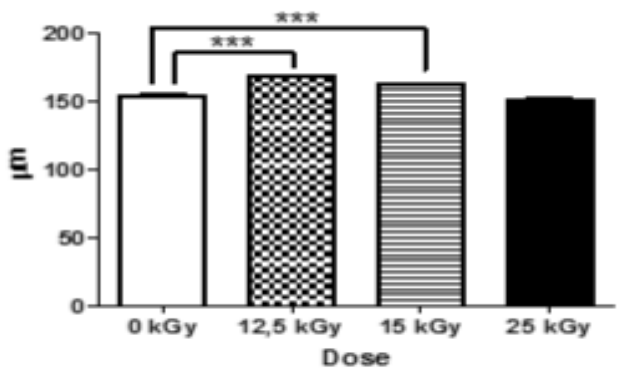

Amostra A05

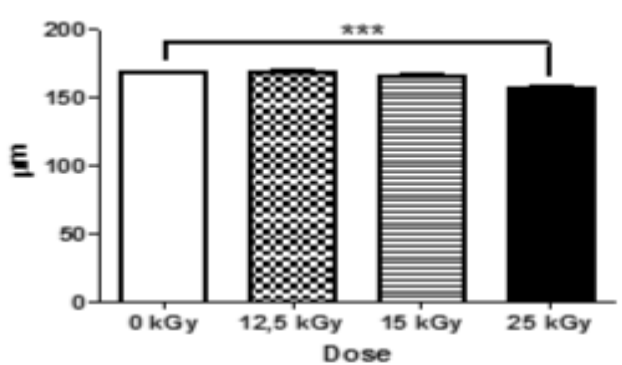

Amos tra $\mathrm{A} 07$

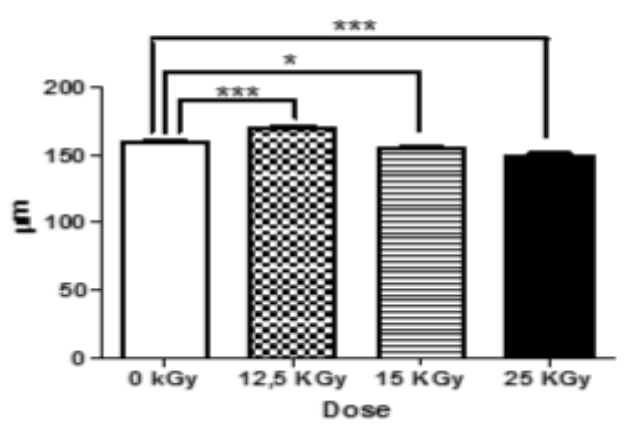

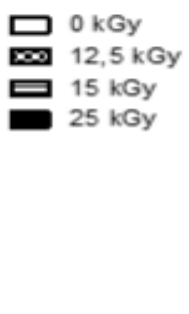
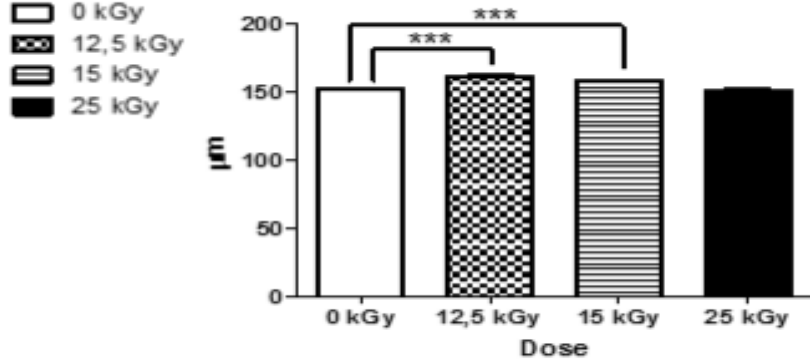

Amostra A06
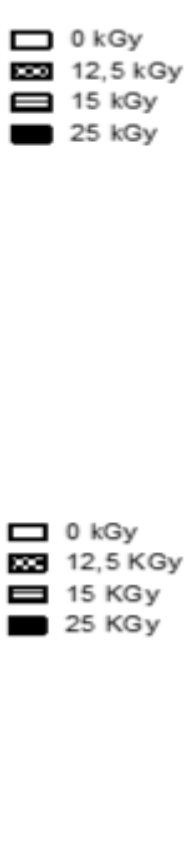

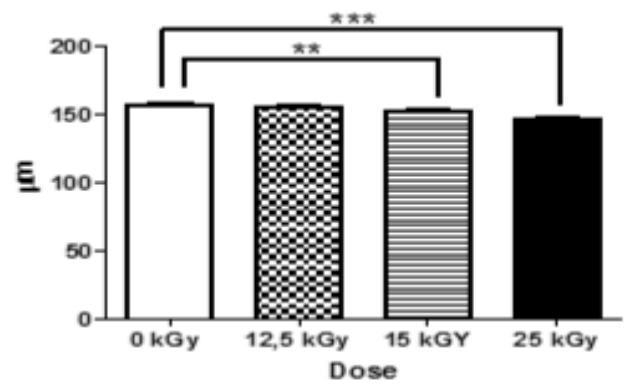

Amostra A08

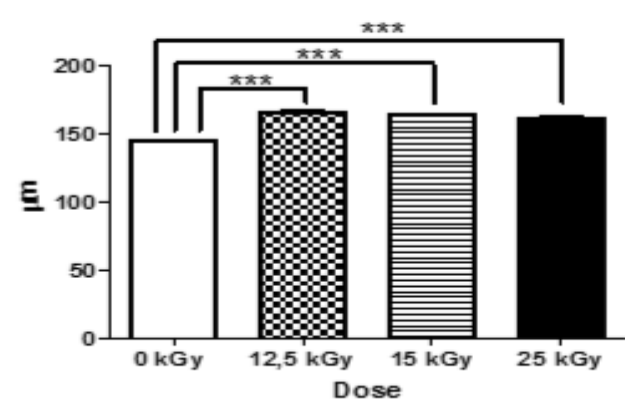

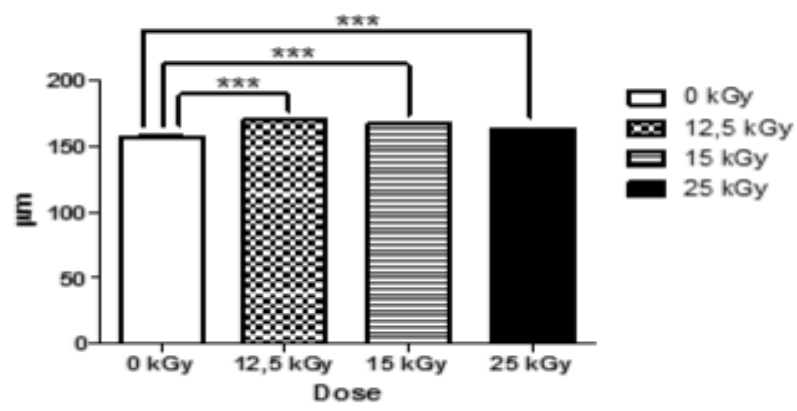

Amostra A04

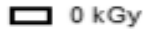

12,5 kGy

च $15 \mathrm{kGy}$

25 kGy
口 $0 \mathrm{kGy}$ 12,5 kGy 口 15 kGY 25 kGy

FIGURA 13. Gráficos comparativos das médias das distâncias entre as bandas de birrefringência, amostras irradiadas em relação ao seu respectivo controle. Utilizando a análise de ANOVA e o teste secundário de Tukey, onde (*) mostra uma correlação positiva pouco significativa, $\left({ }^{* *}\right)$ grau de correlação de significância moderada e $\left.{ }^{(\star \star}\right)$ mostra uma correlação altamente significativa. 
$\mathrm{Na}$ FIG. 13 pode-se observar os dados obtidos (apêndice 1) com as amostras dos tecidos submetidos à análise de variância unifatorial (ANOVA), sendo que os resultados apresentaram diferentes graus de correlação,

As amostras A01, A02 e A08 apresentaram resultados semelhantes quando relacionados os dados dos tendões irradiados, com seus respectivos controles.

As amostras A03 e A04 mostraram uma correlação altamente significativa em relação ao controle e 12,5 kGy e o controle e 15 kGy, e não apresentou significância entre o controle e 25 kGy.

A amostra A05 mostra uma correlação altamente significativa entre 0 controle e $25 \mathrm{kGy}$, porém entre as demais amostras não houve significância.

A amostra A06 mostrou uma correlação altamente significativa entre 0 controle e 25 kGy e uma relação moderada entre o controle e 15 kGy e não apresentou significância entre o controle e 12,5 kGy.

A amostra A07 apresentou uma correlação altamente significativa entre 0 controle e 12,5 kGy e controle e 25 kGy, e apresentou uma correlação de significância moderado entre o controle e 15 kGy.

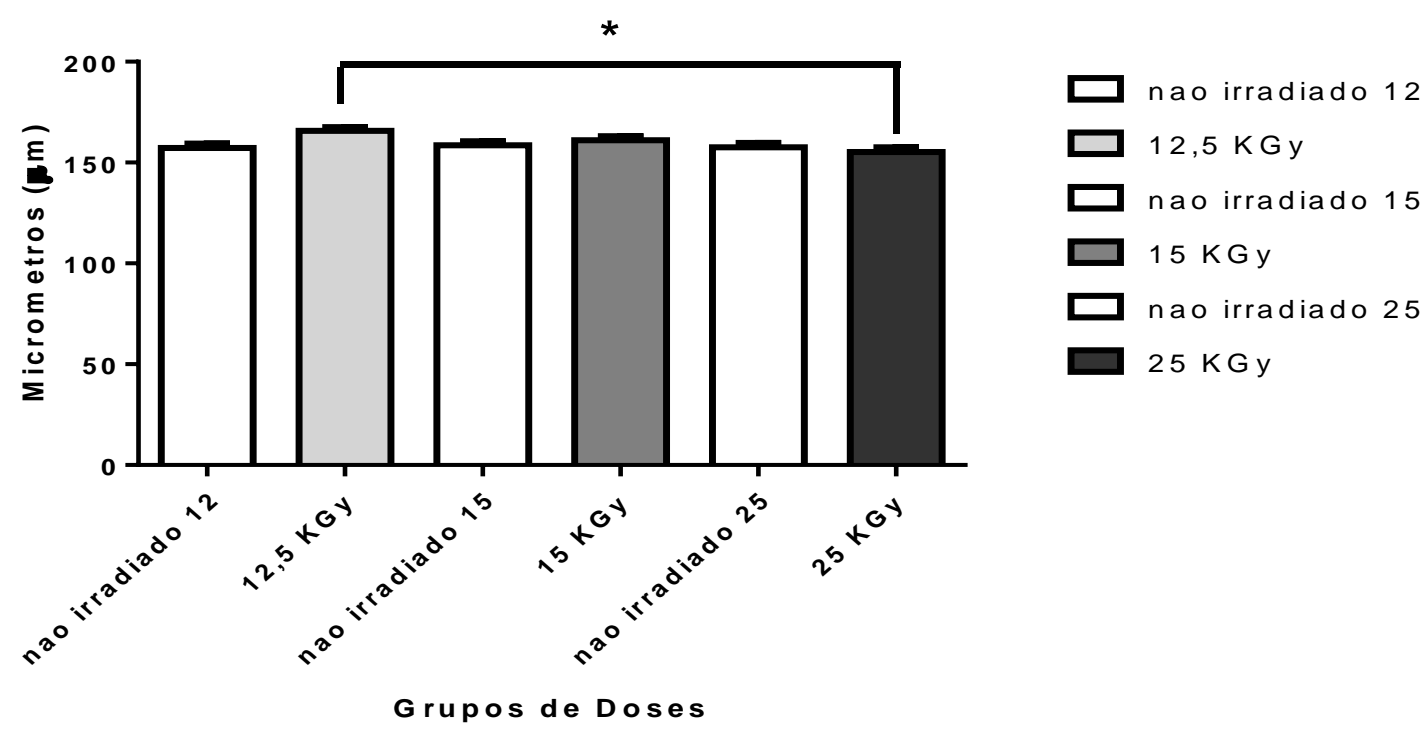

FIGURA 14. Gráfico de análise estatística dos dados das amostras (A) não irradiadas vs irradiadas onde observa-se uma diferença nas amostras de 12 e $25 \mathrm{kGy}$ que não é vista entre as demais amostras, que se apresentam bem similares. 
Somente foi possível observar diferença entre as doses irradiadas de $12,5$ kGy e 25 kGy FIG. 14 ( $p<0,05)$ e as demais amostras quando comparadas entre si não apresentaram grau de significância, esta diferença se deve ao desvio padrão muito pequeno obtido entre as amostras $(<0.9 \%)$, enquanto a diferença entre as amostras não irradiadas (A01 até A08) tem uma variação de 7,2\% a $8,6 \%$.

TABELA 3 - Comparação grupo não irradiado e grupo irradiado

\begin{tabular}{cccccc}
\hline $\begin{array}{c}\text { Grupo } \\
\text { Controle12 }\end{array}$ & $12,5 \mathrm{kGy}$ & $\begin{array}{c}\text { Grupo } \\
\text { Controle15 }\end{array}$ & $15 \mathrm{kGy}$ & $\begin{array}{c}\text { Grupo } \\
\text { Controle25 }\end{array}$ & 25 kGy \\
\hline $157,3 \pm 2,12$ & $165,7 \pm 1,83\left(^{*}\right)$ & $158,7 \pm 1,92$ & $161,1 \pm 2,03$ & $157,6 \pm 2,09$ & $155,3 \pm 2,33\left(^{*}\right)$ \\
\hline \multicolumn{7}{l}{$\left(^{*}\right)$ Valores representam a média \pm desvio padrão significância estatística com ANOVA p<0,05 }
\end{tabular}

Ao comparar os valores intragrupos (irradiados em relação ao seu próprio controle), foi encontrado um valor de $p=0,01$, mostrando não haver diferença significativa entre eles, devido ao desvio padrão muito pequeno.

\subsection{Análise Histológica}

O estudo histológico das amostras foi realizado por meio das técnicas de coloração de hematoxilina/eosina e Picrosirius. 

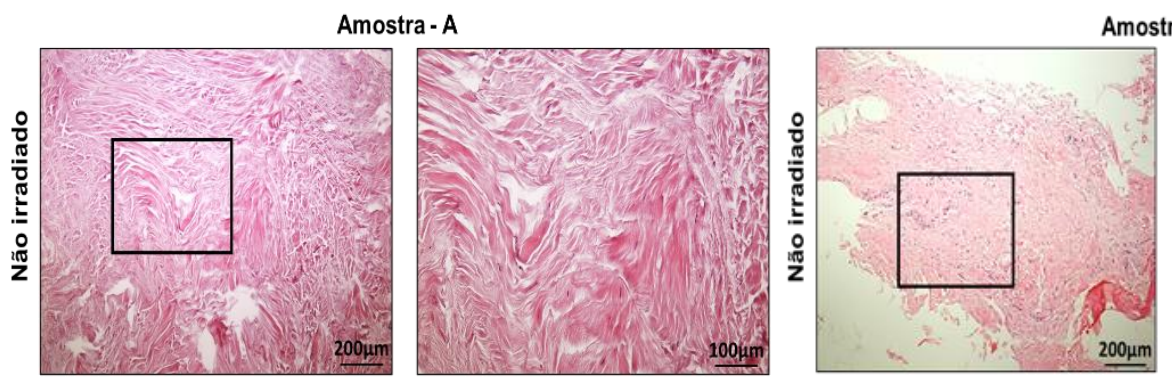

Amostra-B
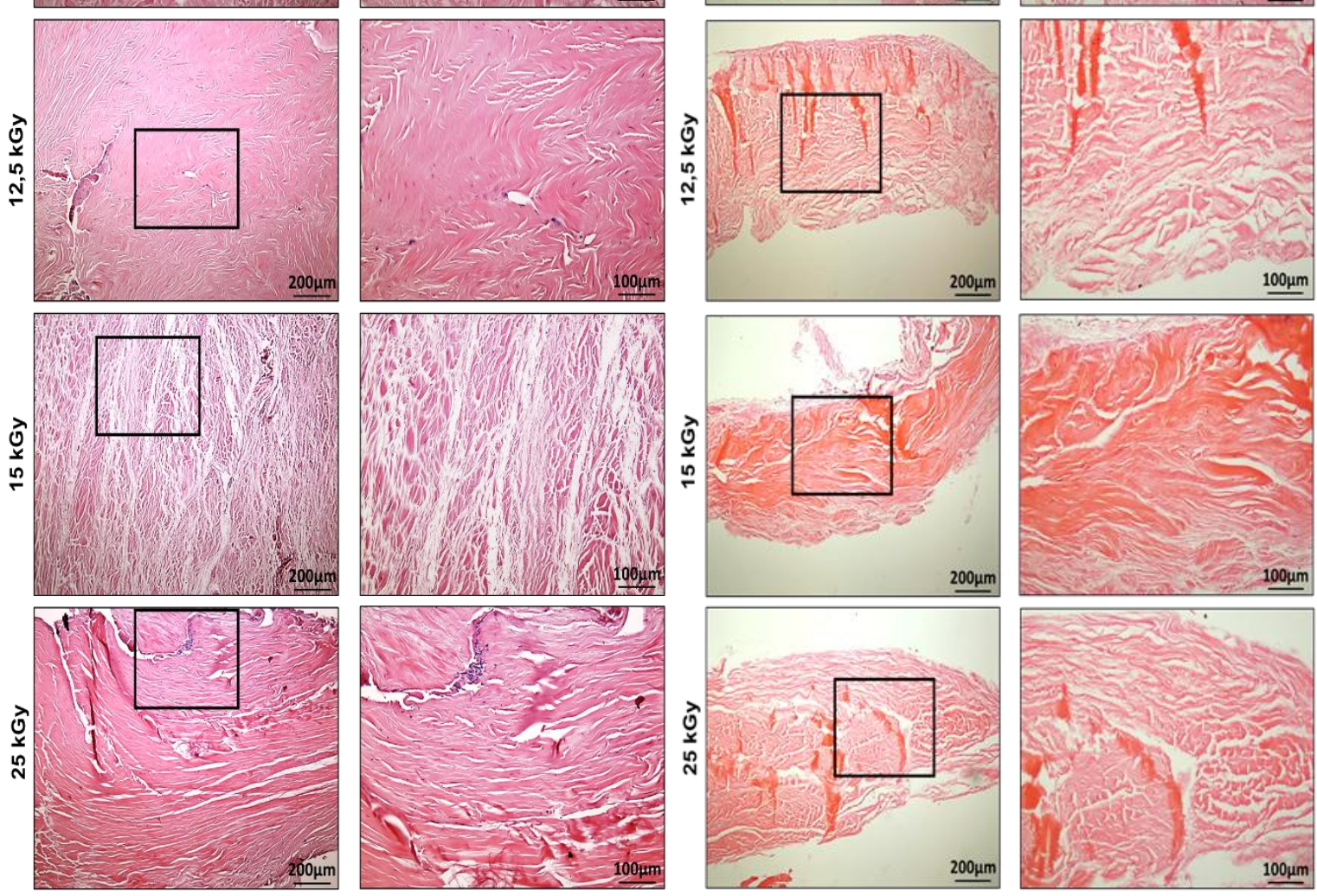

FIGURA 15. Fotomicrografia tendão tibial posterior em cortes histológicos das amostras A e $B$, mostrando feixes paralelos e transversais de fibras colágenas (hematoxilinaeosina, $100 \mu \mathrm{m}$ e $200 \mu \mathrm{m}$ ) amostras controle, 12,5 kGy, 15 kGy e 25 kGy.

$\mathrm{Na}$ FIG. 15 nas amostras A e B pode-se observar um exemplo do aspecto histológico das amostras de tendão tibial corados com HE, observados por microscopia de luz, em aumento de $100 \mu \mathrm{m}$ e $200 \mu \mathrm{m}$. Na amostra A as fibras do tecido apresentam uma distribuição ondulante. $O$ tendão não irradiado (controle) apresenta fibras em diferentes sentidos de orientação, como é característico deste tecido. Na dose de 12,5 kGy observou-se uma alteração nos feixes do tecido apresentando um espaçamento entre fibras, mostrando-se mais semelhante em relação ao controlhe, a dose de $15 \mathrm{kGy}$ a fibra se apresenta mais aberta mais espalhada e com espaçamento entre as fibras e na dose de 25 kGy apresentou uma contração dos feixes de colágeno, com espaçamento maior entre 
as fibras. Este tipo de coloração mostra a morfologia tecidual, permitindo a observação de possíveis alterações, sendo que em nenhuma das amostras foi observa quebra do colágeno.

Nas amostras do método $B$, pode-se observar no controle as mesmas características da amostra A porem, apresentando espaçamento entre as fibras, sendo este espaçamento presente em todas as doses, e quanto maior a dose aplicada maior foi o espaçamento entre as fibras. Sendo que a amostra de 12,5 kGy se mostrou mais semelhante ao controle.

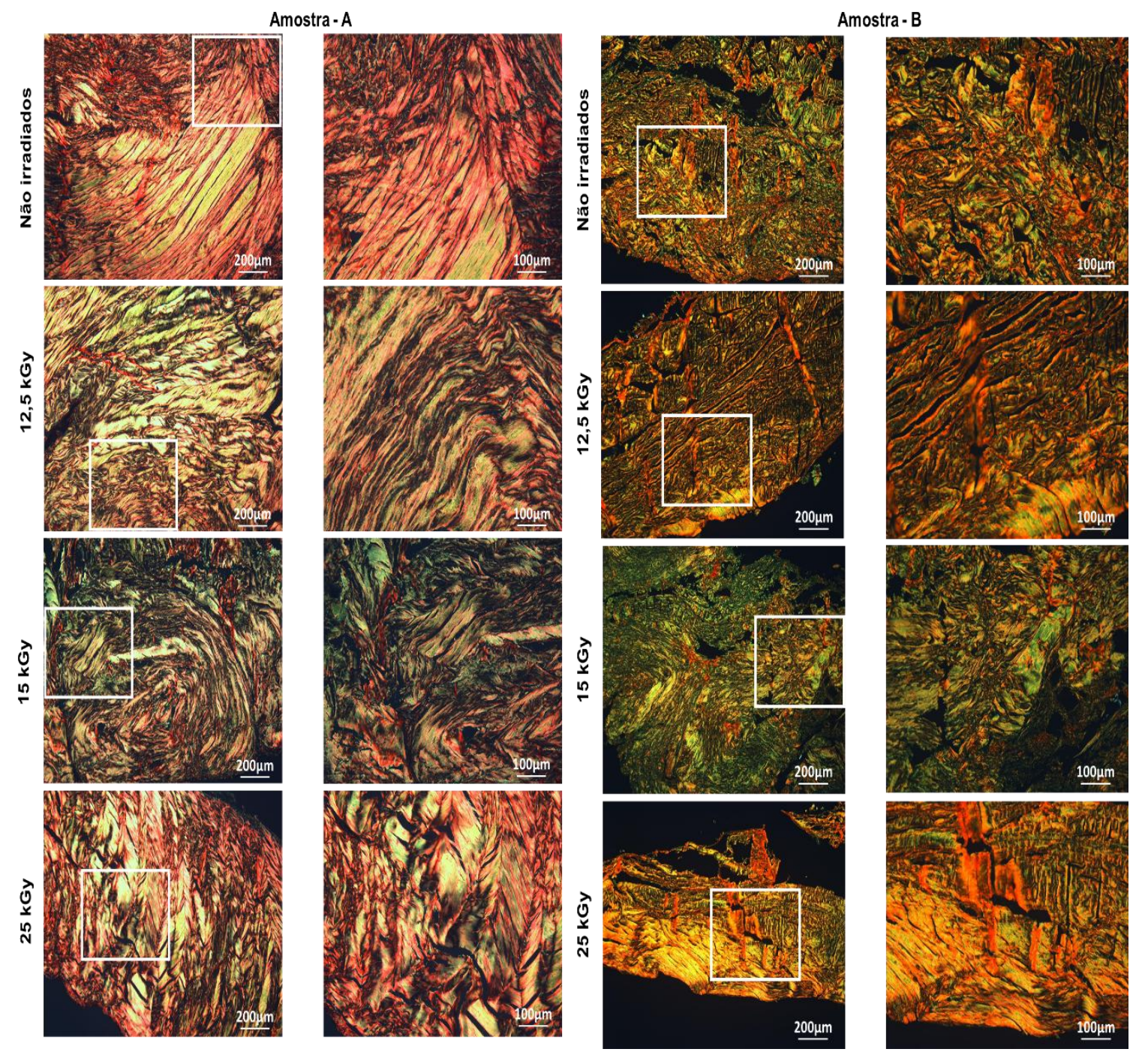

FIGURA 16. Fotomicrografia tendão tibial posterior em cortes histológicos das amostras A e $B$, mostrando feixes paralelos e transversais de fibras colágenas (Picrosirius 100 $\mu \mathrm{m}$ e $\mathbf{2 0 0} \boldsymbol{\mu m}$ ) Coloração alaranjada, rosa para vermelho expressam fibras de maior calibre e verde para azul expressam fibras de menor calibre. 
Na FIG. 16 pode-se observar o aspecto histológico das amostras de tendão tibial corados com Picrosirius, observados por microscopia de luz polarizada, em aumento de $100 \mu \mathrm{m}$ e $200 \mu \mathrm{m}$. O tendão não irradiado (controle) apresenta colorações diferentes em sua área, devido a variação dos tipos de fibras encontrados. Na dose de 12,5 kGy observa-se em maior proporção fibras de maior calibre, porém com aparecimento de fibras de menor calibre, quando comparadas ao controle. Na dose de $15 \mathrm{kGy}$ observa-se uma similaridade entre as proporções de fibras finas e calibrosas. Na dose de $25 \mathrm{kGy}$ é possível observar fibras de maior calibre em toda a amostra e fibras finas na porção mais central do tecido, com uma proporção semelhante ao controle, porém com uma distribuição mais homogênea. Assim como observado na coloração com HE, na amostra irradiada com $25 \mathrm{kGy}$, pode-se observar espaços entre as fibras de colágeno, confirmando que estas se agruparam, possibilitando a visualização de fibras de maior calibre. Nas amostras do método $B$, em relação ao controle, na dose de 12,5 kGy observa-se uma maior semelhança entre as amostras, com presença predominante de fibras de menor calibre por todo o tecido. Nas amostras de 15 kGy observa-se uma predominância das fibras de menor calibre e uma proporção menor de fibras grossas espalhadas por todo tecido. Em relação às amostras de 25 kGy observa-se uma distribuição mais homogenia entre fibras de ambos calibres. 


\subsubsection{Análise quantitativa Picrosirius}

Método A
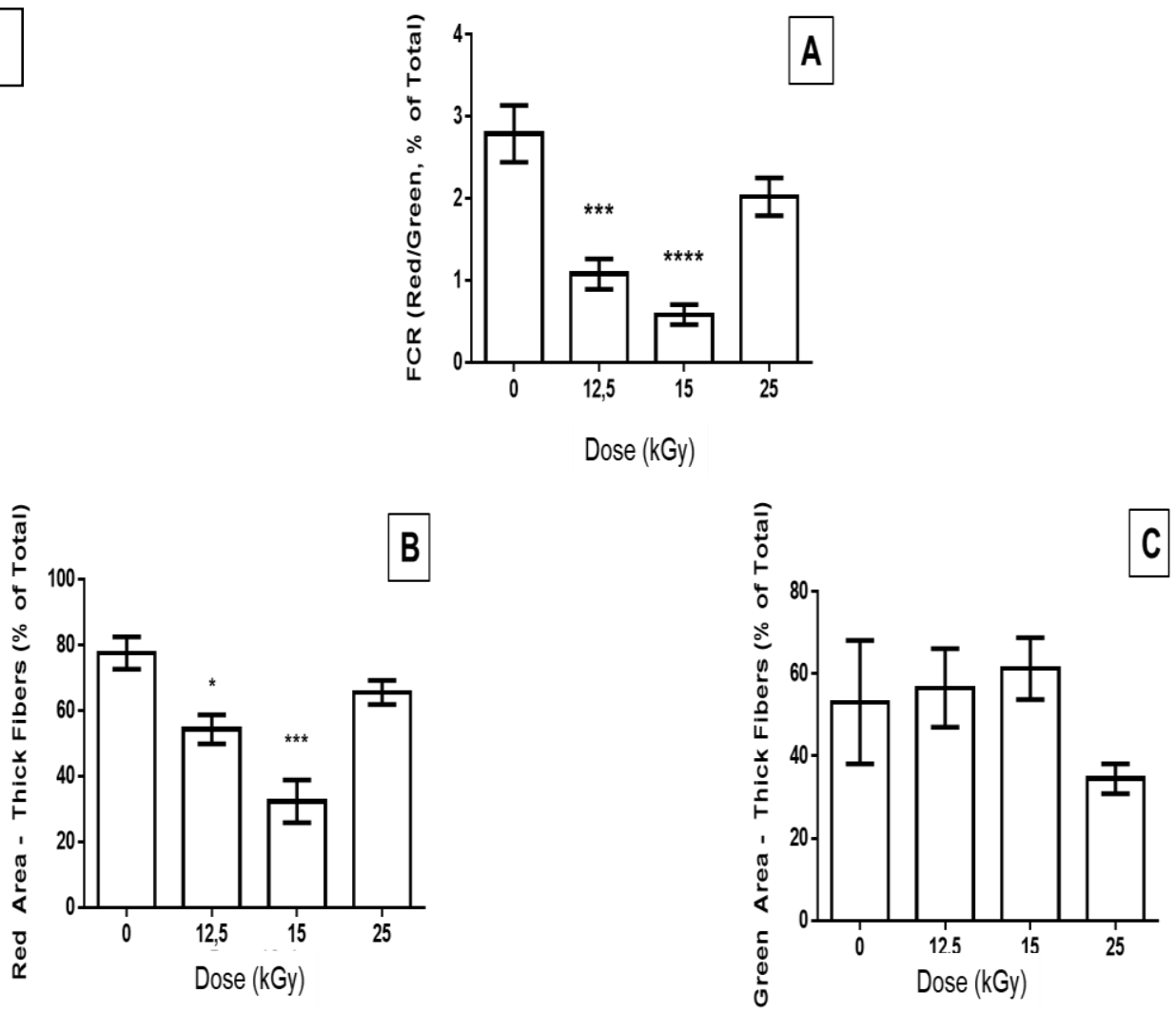

FIGURA 17. Quantificação das imagens obtidas na análise das fotos de Picrosirius (amostra A).

Na FIG. 17 e 18 as amostras dos métodos A e B foram quantificadas utilizando o programa Graph Pad Prism as colorações tanto para fibras grossas (vermelho, rosa e laranja) quanto as fibras finas (verde e azul). Na FIG. 17 amostra do método $A$ foi possível observar que em relação ao controle a amostra de 25 kGy a diferença não foi significativa, apresentando maior similaridade em relação as colorações de fibras grossas e finas. Sendo que as doses de 12,5 e 15 kGy apresentaram, em relação ao controle, um alto grau de significância. No gráfico $B$ foi possível observar a relação percentual da área de fibras grossas, fazendo uma correlação entre as doses e o controle, sendo que a amostra de $25 \mathrm{kGy}$ apresentou uma similaridade maior com o controle, seguido da amostra de 12,5 kGy com uma diferença pouco significativa, já a amostra 15 kGy 
apresentou uma diferença altamente significativa. Em relação às fibras finas observadas no gráfico $\mathrm{C}$, essas fibras mostraram um percentual maior nas doses de 15 kGy e 12,5 kGy em relação ao controle, porem a dose de 25 kGy em relação ao controle e às demais doses pode-se observar uma tendência à uma menor quantidade, no entanto não significante estatisticamente.

Método B
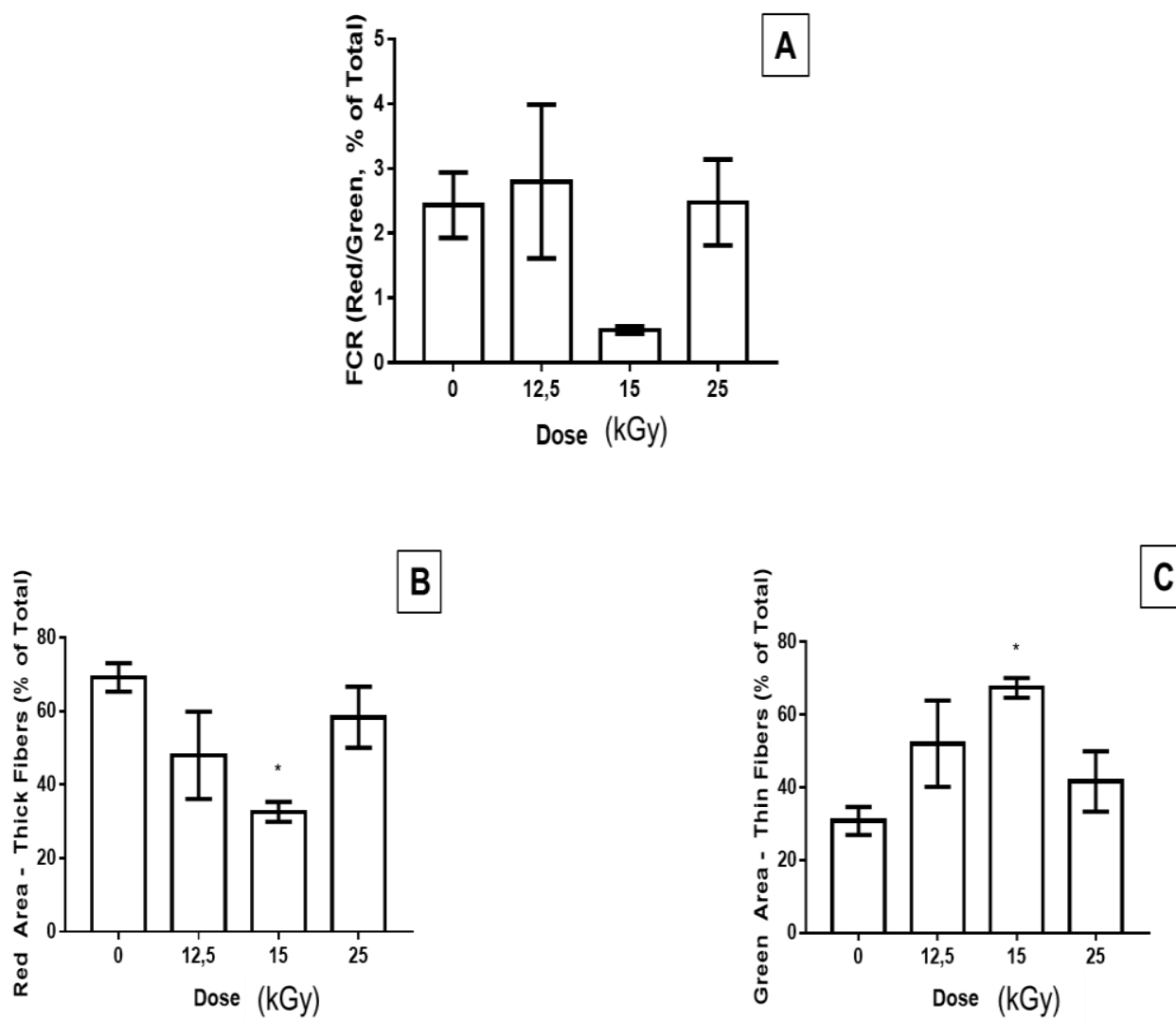

FIGURA 18 Quantificação das imagens obtidas na análise das fotos de Picrosirius (amostra B).

Na FIG. 18 no que diz respeito às amostras do método $B$ no gráfico $A$ foi possível observar que em relação ao controle as amostras de 12,5 e 25 kGy as diferenças nas proporções de fibras finas e grossas não apresentaram grau de significância, apresentando-se mais similar ao controle. Sendo que a dose de 15 kGy apresentou, em relação ao controle, menor proporção destas fibras, comum alto grau de significância. No gráfico B foi possível observar a relação 
percentual da área de fibras grossas, fazendo uma correlação entre as doses e controle, sendo que a amostra de $25 \mathrm{kGy}$ apresentou uma similaridade maior em relação ao controle, seguido da amostra de 12,5 kGy e a amostra de 15 kGy apresentou uma diferença pouco significativa. Com relação às fibras finas observadas no gráfico $\mathrm{C}$, que essas fibras mostraram um percentual maior em todas as doses em relação ao controle, sendo que somente a dose de $15 \mathrm{kGy}$ apresentou uma diferença pouco significativa em relação ao controle.

\subsection{Análise Biomecânica}

\subsubsection{Tração}

Os gráficos da FIG. 18 foram obtidos no primeiro teste experimental realizado em uma amostra não irradiada. Este teste difere da metodologia estabelecida anteriormente por não possuir nenhuma região com carregamento cíclico, ou seja, é puramente monotônico. A realização deste ensaio é uma prática comum dentro da engenharia para entender o comportamento mecânico do material a ser estudado, fornecendo dados importantes no dimensionamento dos testes experimentais. Em outras palavras, este primeiro teste experimental nos forneceu duas informações importantes: a tensão máxima e o modo de falha do tendão, no qual em um determinado momento, mesmo aumentando a deformação, pode-se notar um decréscimo da tensão mecânica. 

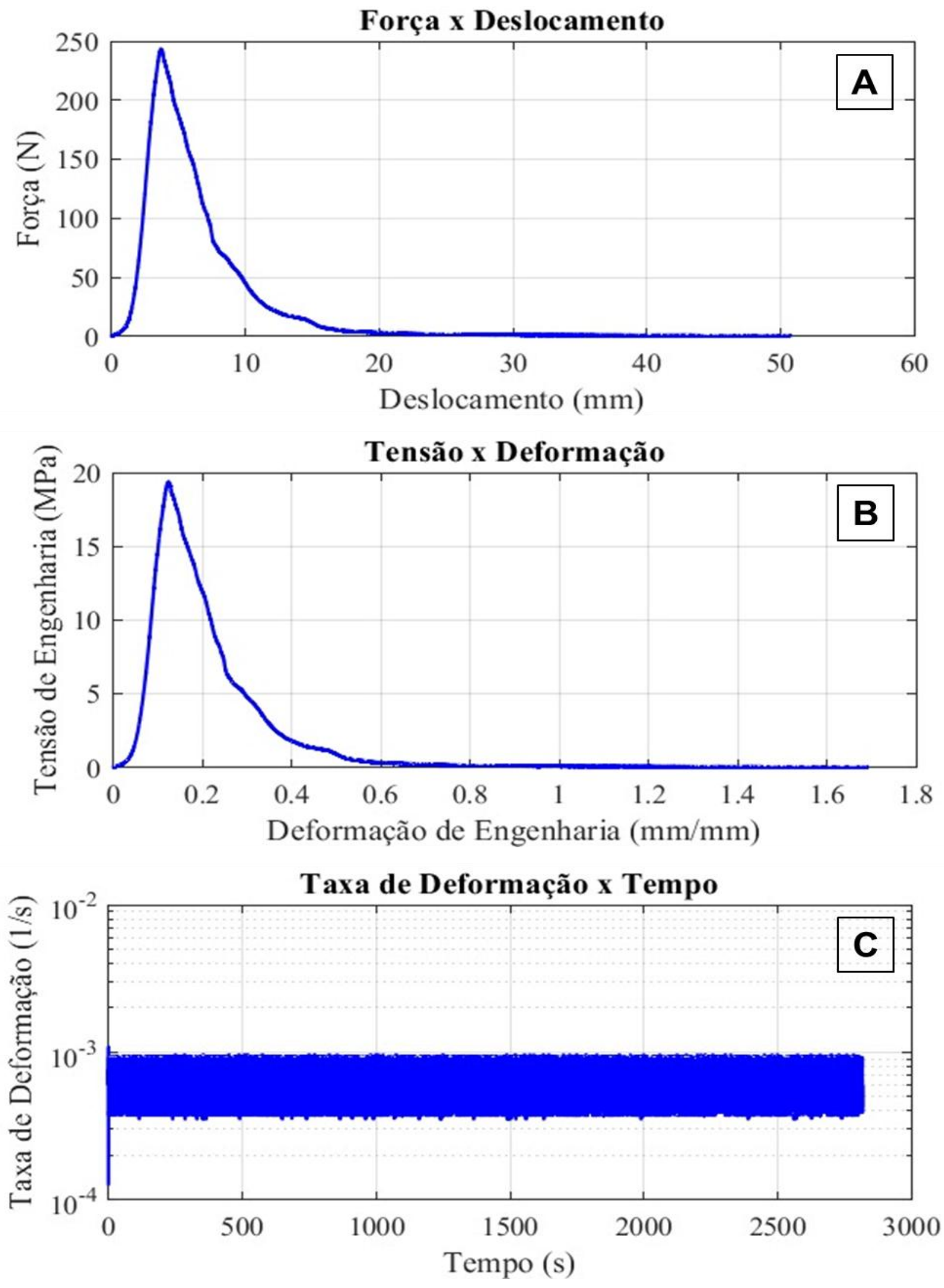

FIGURA 19. Gráficos do teste de tração (A) gráfico força $x$ deformação; (B) gráfico tensão $x$ deformação e (C) gráfico taxa de deformação $x$ tempo. 
Na FIG. 19 no gráfico A, pode-se observar a força em função do deslocamento, sendo clara a força máxima de tração da amostra próximo a 500 N. No Gráfico B observa-se a Tensão (Mpa) em função da deformação, com a tensão máxima próxima de $38 \mathrm{MPa}$. O terceiro gráfico apresenta a taxa de deformação em função do tempo do teste, ficando muito próxima de $10^{-3}$ ou 0,001 $1 / \mathrm{s}$.

\subsubsection{Tensão-deformação}

Do teste monotônico foram obtidos os valores das tensões mínimas e máximas. Como cada corpo de prova possui área de secção transversal diferente, foram calculados os valores de $F_{\min }$ e $F_{\max }$ relativos a $5 \%$ e $25 \%$ do valor da tensão máxima, sendo estes os valores limitantes para a parte cíclica dos ensaios, ou seja, as partes 1, 2, 3 e 4. Os resultados obtidos estão descritos nas tabelas TAB.4, TAB.5, TAB.6 e TAB.7, cada uma em função de diferentes doses de radiação.

TABELA 4 - Dados das amostras controle não irradiado para cálculo de força mínima e máxima

\begin{tabular}{|c|c|c|c|c|c|c|c|c|c|}
\hline & $\begin{array}{c}\text { Corpo } \\
\text { de } \\
\text { prova }\end{array}$ & Idade/sexo & $\begin{array}{l}\text { Número } \\
\text { do teste }\end{array}$ & Larg & Esp & comp & $\begin{array}{l}\text { Área } \\
\left(\mathrm{mm}^{2}\right)\end{array}$ & $\mathrm{F}_{\min }$ & $F_{\max }$ \\
\hline \multirow{5}{*}{$\mathrm{A} 0$} & CP1 & $42 / F$ & 1 & 2,60 & 1,34 & 2,00 & 3,48 & 3,83 & 31,70 \\
\hline & $\mathrm{CP} 2$ & $39 / \mathrm{M}$ & 2 & 4,90 & 1,34 & 2,50 & 6,57 & 7,22 & 59,75 \\
\hline & $\mathrm{CP} 3$ & $30 / \mathrm{M}$ & 3 & 4,20 & 2,44 & 2,00 & 10,25 & 11,27 & 93,26 \\
\hline & $\mathrm{CP} 4$ & $42 / \mathrm{F}$ & 4 & 4,70 & 1,07 & 2,50 & 5,03 & 5,53 & 45,76 \\
\hline & CP5 & $39 / \mathrm{M}$ & 5 & 4,24 & 1,11 & 2,00 & 4,71 & 5,18 & 42,83 \\
\hline \multirow{5}{*}{ BO } & $\mathrm{CP} 1$ & $52 / \mathrm{M}$ & 6 & 2,79 & 2,02 & 2,50 & 5,64 & 6,20 & 51,29 \\
\hline & $\mathrm{CP} 2$ & $42 / \mathrm{M}$ & 7 & 3,62 & 1,03 & 2,50 & 3,73 & 4,10 & 33,93 \\
\hline & CP3 & $52 / \mathrm{F}$ & 8 & 4,50 & 1,53 & 2,50 & 6,89 & 7,57 & 62,65 \\
\hline & $\mathrm{CP} 4$ & $42 / F$ & 9 & 4,64 & 1,22 & 2,00 & 5,66 & 6,23 & 51,51 \\
\hline & CP5 & $35 / F$ & 10 & 1,53 & 1,79 & 2,00 & 2,74 & 3,01 & 24,92 \\
\hline
\end{tabular}


TABELA 5 - Dados das amostras irradiadas 12,5 kGy

\begin{tabular}{|c|c|c|c|c|c|c|c|c|c|}
\hline & $\begin{array}{c}\text { Corpo } \\
\text { de } \\
\text { prova }\end{array}$ & Idade/sexo & $\begin{array}{l}\text { Número } \\
\text { do teste }\end{array}$ & Larg & Esp & comp & $\begin{array}{l}\text { Área } \\
\left(\mathrm{mm}^{2}\right)\end{array}$ & $\mathrm{F}_{\min }$ & $\mathrm{F}_{\max }$ \\
\hline \multirow{5}{*}{ A1 } & $\mathrm{CP} 1$ & $18 / \mathrm{M}$ & 11 & 3,58 & 1,39 & 2,40 & 4,98 & 5,47 & 45,28 \\
\hline & $\mathrm{CP} 2$ & $30 / \mathrm{M}$ & 12 & 4,72 & 2,17 & 2,50 & 10,24 & 11,27 & 93,21 \\
\hline & CP3 & $39 / M$ & 13 & 4,51 & 1,12 & 2,00 & 5,05 & 5,56 & 45,97 \\
\hline & $\mathrm{CP} 4$ & $42 / \mathrm{M}$ & 14 & 2,61 & 1,28 & 2,00 & 3,34 & 3,67 & 30,40 \\
\hline & CP5 & $42 / \mathrm{M}$ & 15 & 2,69 & 1,27 & 2,00 & 3,42 & 3,76 & 31,09 \\
\hline \multirow{5}{*}{ B1 } & CP1 & $52 / \mathrm{M}$ & 16 & 3,06 & 1,27 & 2,40 & 3,89 & 4,27 & 35,36 \\
\hline & $\mathrm{CP} 2$ & $35 / \mathrm{F}$ & 17 & 3,60 & 2,21 & 2,50 & 7,96 & 8,75 & 72,40 \\
\hline & CP3 & $42 / \mathrm{F}$ & 18 & 3,64 & 1,02 & 2,00 & 3,71 & 4,08 & 33,79 \\
\hline & CP4 & $43 / M$ & 19 & 3,59 & 1,34 & 2,00 & 4,81 & 5,29 & 43,78 \\
\hline & CP5 & $42 / \mathrm{M}$ & 20 & 3,31 & 1,20 & 2,00 & 3,97 & 4,37 & 36,15 \\
\hline
\end{tabular}

TABELA 6 - Dados das amostras irradiadas 15 kGy

\begin{tabular}{|c|c|c|c|c|c|c|c|c|c|}
\hline & $\begin{array}{c}\text { Corpo } \\
\text { de } \\
\text { prova }\end{array}$ & Idade/sexo & $\begin{array}{l}\text { Número } \\
\text { do teste }\end{array}$ & Larg & Esp & comp & $\begin{array}{c}\text { Área } \\
\left(\mathrm{mm}^{2}\right)\end{array}$ & $\mathrm{F}_{\min }$ & $F_{\max }$ \\
\hline \multirow{5}{*}{$\mathrm{A} 2$} & $\mathrm{CP} 1$ & $18 / \mathrm{F}$ & 21 & 4,39 & 1,65 & 2,50 & 7,24 & 7,97 & 65,92 \\
\hline & $\mathrm{CP} 2$ & $30 / \mathrm{M}$ & 22 & 3,35 & 1,79 & 2,60 & 6,00 & 6,60 & 54,57 \\
\hline & $\mathrm{CP} 3$ & $30 / \mathrm{M}$ & 23 & 4,29 & 1,97 & 2,00 & 8,45 & 9,30 & 76,91 \\
\hline & CP4 & $39 / \mathrm{M}$ & 24 & 4,16 & 1,80 & 2,00 & 7,49 & 8,24 & 68,14 \\
\hline & CP5 & $39 / M$ & 25 & 4,84 & 1,80 & 2,00 & 8,71 & 9,58 & 79,28 \\
\hline \multirow{5}{*}{ B2 } & $\mathrm{CP} 1$ & $43 / \mathrm{M}$ & 26 & 4,71 & 1,41 & 2,60 & 6,64 & 7,31 & 60,43 \\
\hline & $\mathrm{CP} 2$ & $28 / \mathrm{M}$ & 27 & 2,74 & 1,30 & 2,60 & 3,56 & 3,92 & 32,41 \\
\hline & CP3 & $52 / \mathrm{M}$ & 28 & 3,96 & 1,47 & 2,00 & 5,82 & 6,40 & 52,97 \\
\hline & CP4 & $39 / \mathrm{M}$ & 29 & 3,44 & 1,20 & 2,00 & 4,13 & 4,54 & 37,56 \\
\hline & CP5 & $42 / F$ & 30 & 3,91 & 1,80 & 2,00 & 7,04 & 7,74 & 64,05 \\
\hline
\end{tabular}

TABELA 7 - Dados das amostras irradiadas 25 kGy

\begin{tabular}{|c|c|c|c|c|c|c|c|c|c|}
\hline & $\begin{array}{c}\text { Corpo } \\
\text { de } \\
\text { prova }\end{array}$ & Idade/sexo & $\begin{array}{l}\text { Número } \\
\text { do teste }\end{array}$ & Larg & Esp & comp & $\begin{array}{l}\text { Área } \\
\left(\mathrm{mm}^{2}\right)\end{array}$ & $\mathrm{F}_{\min }$ & $F_{\max }$ \\
\hline \multirow{5}{*}{ A3 } & CP1 & $18 / \mathrm{F}$ & 31 & 3,84 & 1,80 & 2,45 & 6,91 & 7,60 & 62,90 \\
\hline & $\mathrm{CP} 2$ & $42 / F$ & 32 & 3,80 & 1,84 & 2,30 & 6,99 & 7,69 & 63,63 \\
\hline & CP3 & $39 / \mathrm{M}$ & 33 & 3,80 & 1,19 & 2,00 & 4,52 & 4,97 & 41,15 \\
\hline & $\mathrm{CP} 4$ & $30 / \mathrm{M}$ & 34 & 4,92 & 1,50 & 2,00 & 7,38 & 8,12 & 67,16 \\
\hline & CP5 & $39 / \mathrm{M}$ & 35 & 4,37 & 1,09 & 2,00 & 4,76 & 5,24 & 43,35 \\
\hline \multirow{5}{*}{ B3 } & CP1 & $52 / \mathrm{M}$ & 36 & 3,29 & 1,64 & 2,48 & 5,40 & 5,94 & 49,10 \\
\hline & $\mathrm{CP} 2$ & $35 / F$ & 37 & 3,41 & 1,45 & 2,45 & 4,94 & 5,44 & 44,99 \\
\hline & CP3 & $42 / \mathrm{M}$ & 38 & 3,82 & 1,08 & 2,00 & 4,13 & 4,54 & 37,54 \\
\hline & CP4 & $42 / F$ & 39 & 3,92 & 1,17 & 2,00 & 4,59 & 5,05 & 41,74 \\
\hline & CP5 & $52 \mathrm{M}$ & 40 & 3,44 & 1,09 & 2,00 & 3,75 & 4,12 & 34,12 \\
\hline
\end{tabular}


As curvas tensão deformação de todos os testes estão apresentadas na FIG. 20. Cada gráfico representa um determinado método de processamento e quantidade específica de irradiação.
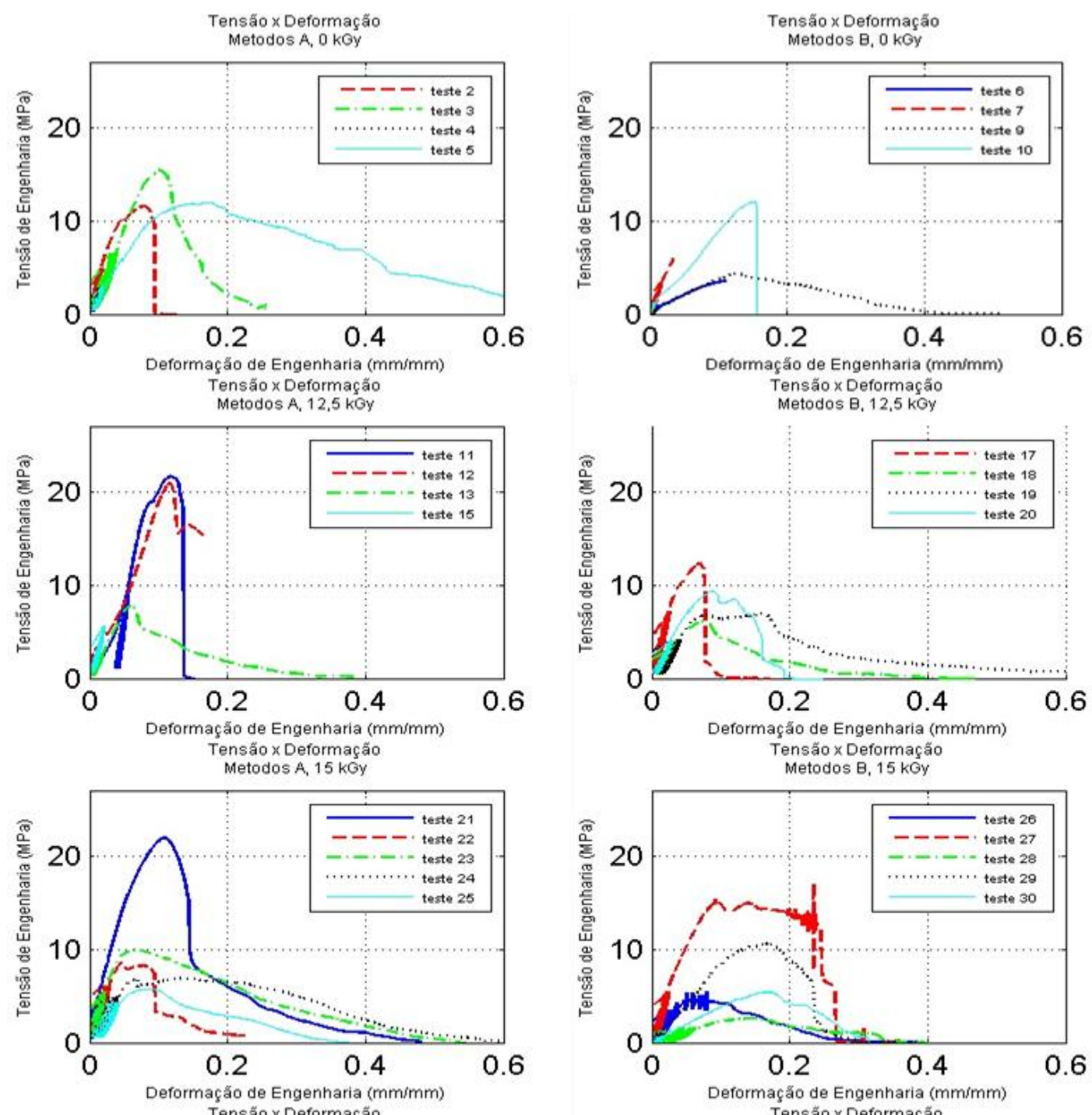

Tensaox Deformaç
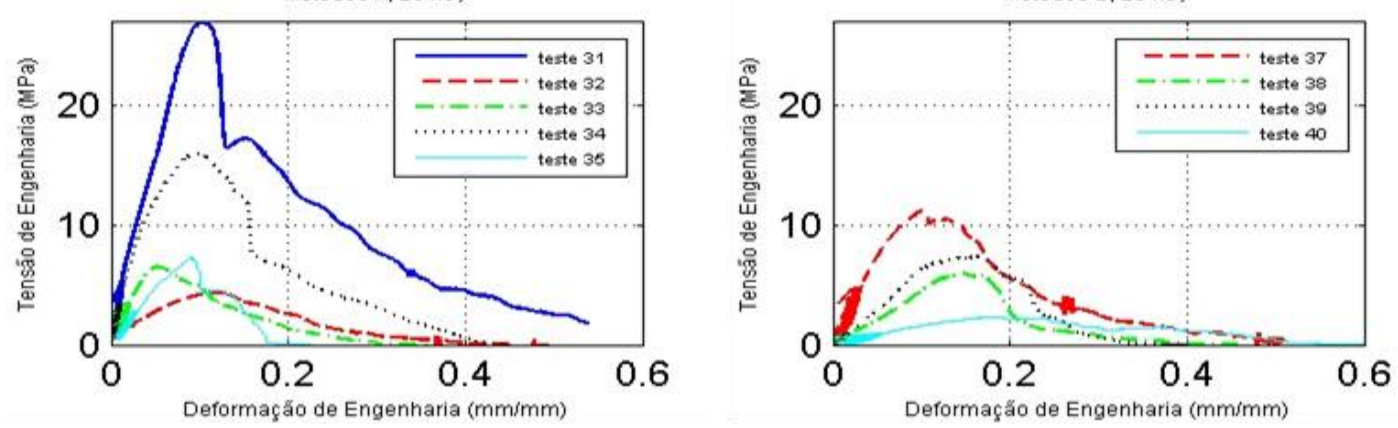

FIGURA 20. Análise de tensão deformação método $A$ e método $B$ nos respectivos controles e doses de 12,5 kGy, 15 kGy e 25 kGy. 
A partir dos dados apresentados na FIG. 20 foi possível avaliar estatisticamente tanto a tensão máxima quanto o comportamento elástico das amostras. Estes dados estão presentes nas figuras FIG. 21 e FIG. 22. Um terceiro gráfico, presente na FIG. 23 , analisa estatisticamente a viscoelasticidade das amostras. As doses de irradiação do eixo horizontal seguem o mesmo modelo do Quadro 2.

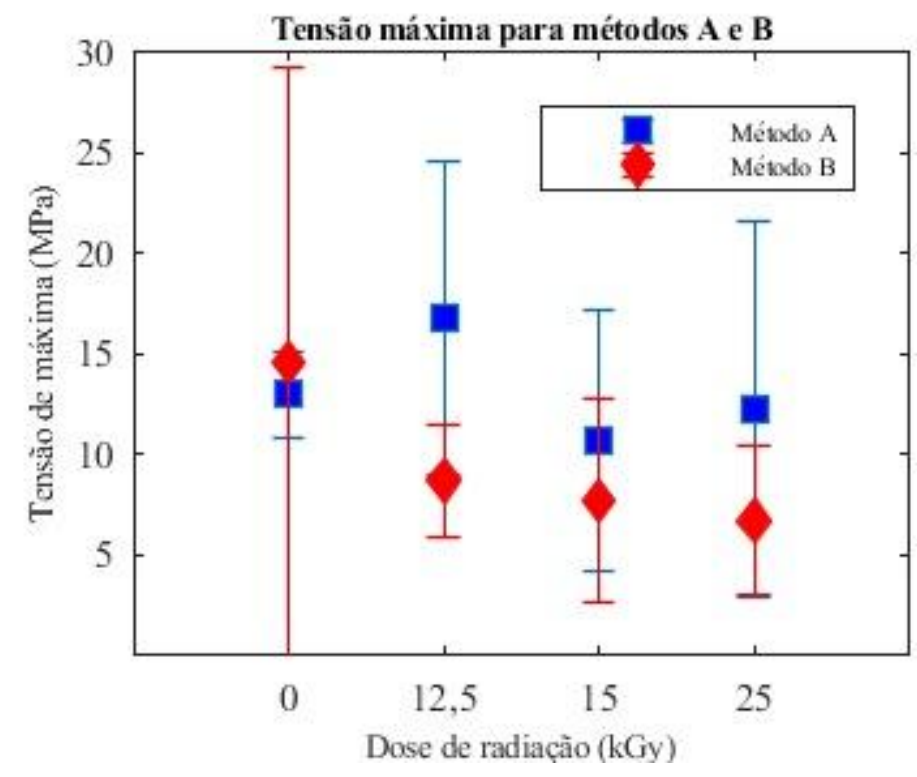

FIGURA 21. Gráfico de comparação da tensão máxima $x$ dose método $A$ e $B$.

Na FIG. 21 pode-se observar os valores de tensão máxima nas amostras de controle e irradiadas, para ambos os tipos de processamento. A primeira observação é de que há uma tendência do método A proporcionando uma melhor resistência mecânica independente da dose de radiação. Observando-se o método $A$, nota-se que há uma tendência de melhora da resistência mecânica ao aumentar a dose de radiação acima da determinada pela norma (15 kGy). Esse fenômeno não pode ser presenciado nas amostras processadas pelo método $B$. 


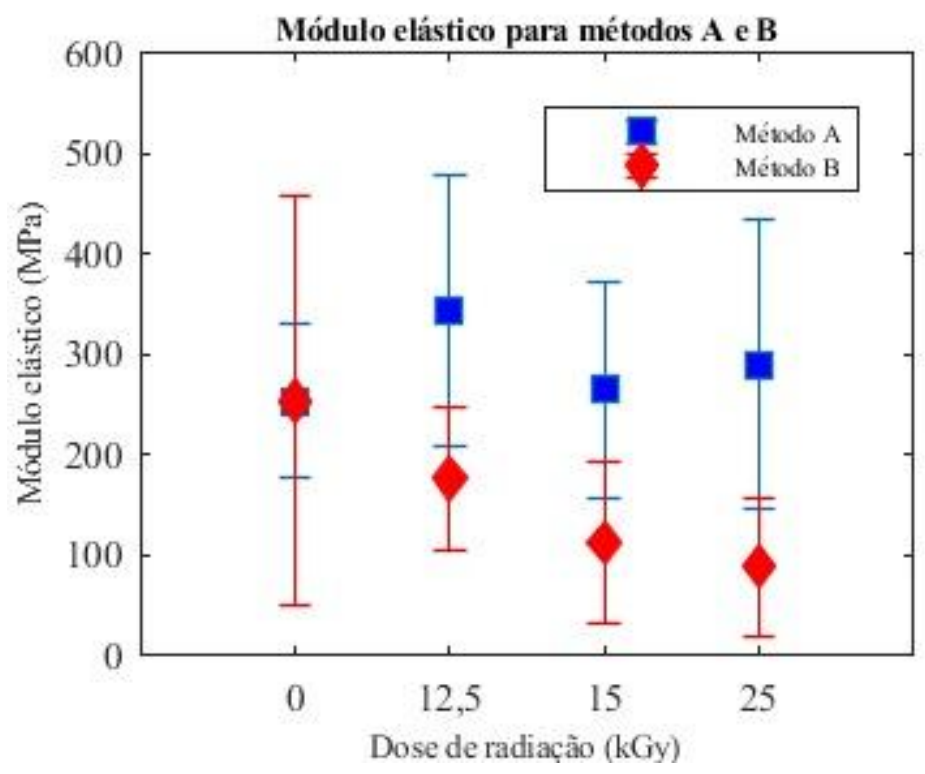

FIGURA 22. Gráfico do módulo elástico das amostras dos métodos A e B.

$\mathrm{Na}$ FIG. 22 pode-se observar os valores de elasticidade máxima nas amostras controle e irradiadas, para ambos tipos de processamento. Observa-se que há uma tendência do método $A$ proporcionando uma melhor resistência mecânica independente da dose de radiação. Observando-se o método A, notase que há uma tendência de melhora da elasticidade ao aumentar a dose de radiação acima da determinada pela norma (15 kGy). Esse fenômeno não pode ser notado nas amostras processadas pelo método B.

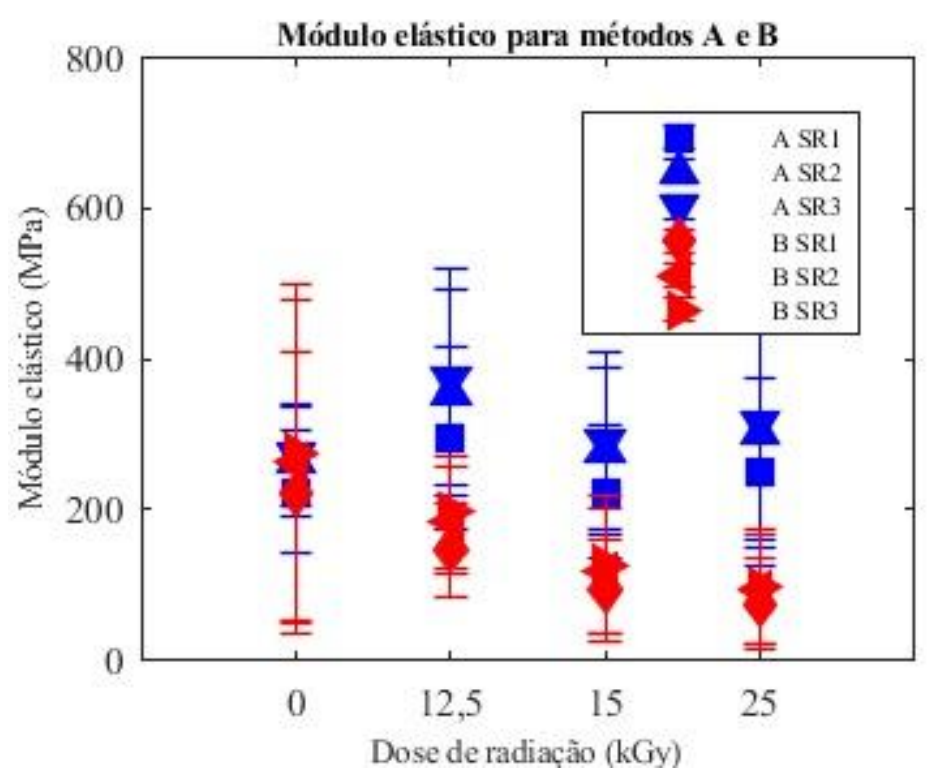

FIGURA 23. Gráfico de comparação módulo elástico das três taxas diferentes de deformação dos métodos $\mathrm{A}$ e $\mathrm{B}$. 
Na FIG. 23 pode-se observar os valores de viscoelasticidade nas amostras de controle e irradiadas, para ambos tipos de processamento. Quanto maior a separação entre o módulo elástico para diferentes taxas de deformação, maior a viscoelasticidade presente na amostra. Observou-se que há uma tendência do método $\mathrm{A}$ proporcionando uma maior viscoelasticidade independente da dose de radiação. Observando-se 0 método $B$, nota-se que há uma tendência da diminuição da viscoelasticidade ao aumentar a dose de radiação. 


\section{DISCUSSÃO}

Para avaliar se os processamentos recebidos pelas amostras em conjunto com a radiação ionizante ocasionam alterações em tendões humanos, usualmente utilizados por bancos de tecidos, após o processamento prévio (vide materiais e métodos 4.4 .1 e 4.4.2) e a irradiação, avaliou-se o comportamento das amostras tendíneas com testes ópticos, por meio de analise por Tomografia de Coerência Óptica (OCT), Tomografia de Coerência Óptica Sensível a polarização (PS-OCT), testes histológicos de Hematoxilina e Eosina (HE) e Picrosirius, e testes biomecânicos de tração e tensão-deformação.

Aloenxertos de tecido humano são comumente utilizados em uma variedade de aplicações clínicas. Desde os anos 90, a maioria dos aloenxertos clinicamente disponíveis foram descontaminados para minimizar o risco de transmissão de doenças. Uma segurança adicional pode ser proporcionada por meio de esterilização final usando radiação gama. Além de esterilidade microbiana, no entanto, ter certeza da não existência de vírus é essencial para garantir a segurança do tecido (Moore, 2012), porém como as doses virais em geral devem ser acima de 50 kGy, dose esta que poderia alterar significativamente o tendão, os Bancos de Tecidos têm que se valer da avaliação inicial do doador, da sorologia e de testes mais sensíveis de biologia molecular para minimizar este tipo de risco.

A esterilização é um passo fundamental no processamento de biomateriais e a mesma não deve comprometer sua funcionalidade (Moraes e col., 2014).

Os resultados obtidos nos testes macroscópicos e no OCT nos permitiram observar diferenças na estrutura das amostras dos métodos de processamento utilizados, o que pode ser verificado na FIG. 10. Nas amostras do método A (FIG. 10 A e B) observa-se um tecido sem alteração em sua estrutura, mantendo assim suas características, já nas amostras do método B foram observadas alterações e a descaracterização da amostra tanto nas sua aparência quanto em sua estrutura. Possivelmente esse efeito na amostra foi ocasionado pelo efeito de 
cavitação do ultrassom em conjunto com uma solução, neste caso o peroxido de hidrogênio.

Segundo Gogate e Pandit (2000 e 2004) a cavitação é a formação, crescimento e colapso subsequente de micro-bolhas, que ocorrem em intervalos muito pequenos de tempo. Sendo acompanhado do lançamento de grande energia em um local muito pequeno produzindo temperaturas extremas e gradientes de pressão.

Dos dois processamentos utilizados nos tecidos, apenas a metodologia $\mathrm{A}$ não apresentou modificações na sua estrutura macroscópica, sendo que a metodologia $B$ devido aos problemas apresentados pelo processamento adotado, mostrou alterações na estrutura tecidual deixando o tecido descaracterizado, e após a realização das imagens no PS-OCT, estas serviram para confirmar o que já era evidente em uma análise visual do material, provando-se assim que a metodologia $B$ não é eficaz para este tipo de tecido e por tanto não devendo ser utilizada para o processamento de tecidos moles como o tendão.

A caracterização óptica de tecidos biológicos apresenta diversas vantagens sobre outras técnicas de diagnostico. Técnicas ópticas mostram uma alta resolução e contraste e uma natureza não invasiva. Geralmente, somente a intensidade de medida é considerada em imagem óptica de tecidos biológicos. A introdução da luz polarizada nas medidas pode fornecer parâmetros adicionais e valiosos (Fanjul-Vélez e col., 2010).

A análise das imagens obtidas por PS-OCT mostraram, que mesmo após a irradiação das amostras que nas amostras do método $A$ foram mantidas as propriedades de birrefringência nas diferentes doses, ou seja, as fibras mantiveram a sua organização (FIG. 11). Nas amostras do método B observou-se uma desorientação no alinhamento das fibras no tecido não irradiado, e no irradiado é possível ver esta desorganização com uma certa dificuldade pois ocorreu uma diminuição na birrefringência das fibras dificultando a visualização das mesmas (FIG. 12).

A análise estatística dos dados obtidos (TAB. 2) mostrou uma diferença significativa das médias das distâncias entre as bandas de birrefringência de cada uma das amostras. Para cada amostra foi feita a comparação de cada uma das doses com seu respectivo controle do mesmo lote (FIG 13). 
Estas alterações das distâncias entre as bandas de birrefringência, podem significar um maior espaçamento entre as fibras de colágeno presentes no tecido.

Analisando o gráfico feito (FIG. 14) com os resultados (TAB. 3) das medidas de birrefringência obtidas com o PS-OCT, foi possível observar uma diferença estatística entre as amostras irradiadas com doses de 12,5 kGy e 25 kGy, devido a tipos opostos de alterações em relação ao seu controle. Estes resultados foram comprovados histologicamente, onde pode-se confirmar a hipótese levantada anteriormente.

Verificou-se que mesmo tendo ocorrido entre as amostras diferentes graus de significância (FIG. 14), esses valores se mostraram muito pouco significantes, provavelmente devido ao pequeno desvio padrão de cada amostra $(<0,9 \%)$, em relação à variação encontrada entre as diferentes amostras de tendão avaliadas $(7,2 \%$ a $8,6 \%)$.

$\mathrm{Na}$ análise histológica de HE pode-se observar uma diferença na estrutura do tecido irradiado, os feixes de colágeno se apresentavam como um conjunto homogêneo, após a irradiação apresentando espaçamento entre fibras e este espaço apresentou um maior distanciamento de acordo com o aumento da dose aplicada, como já descrito na literatura (Seto e col., 2012).

No controle o espaçamento entre fibras é mais fechado ou menos presente do que nas amostras irradiadas, nestas amostras é possível observar mais espaços entre as fibras denotando algum tipo de desorganização no tecido.

O principal constituinte do tecido conjuntivo é o colágeno. A qualidade e organização das fibras de colágeno afetam significativamente a resistência à tração do tecido conjuntivo. O método de polarização da coloração de Picrosirius é um procedimento histoquímico seletivo para detecção de colágeno em seções de tecido embebidas em parafina. Os colágenos exibem diferentes cores de interferência e intensidades de birrefringência em secções de tecidos, analisadas com o auxílio deste método, o que também é útil para estudar a distribuição diferencial das fibras colágenas (Borges, 2007). As fibras grossas ou de maior calibre são identificadas nos tons alaranjado, rosa e vermelho e as menos calibrosas em verde e azulado.

No controle pode-se observar uma grande variação de tipos de fibras, porém com maior visualização de fibras calibrosas. Na dose de 12,5 kGy observa- 
se o aparecimento de maior quantidade de fibras de coloração verde, que poderiam significar o aparecimento de fibras finas, porém esta coloração poderia ser devido ao relaxamento destas fibras, como foi observado na coloração de HE.

$\mathrm{Na}$ dose $15 \mathrm{kGy}$ observa-se uma proporção equivalente de fibras alaranjadas e verdes e uma pequena proporção de fibras vermelhas, portanto, aparentando a existências de uma maior proporção de fibras mais calibrosas.

$\mathrm{Na}$ dose de $25 \mathrm{kGy}$ é possível observar fibras de maior calibre presentes em toda extensão do tecido e fibras menos calibrosas, mais centralizadas, confirmando sua contração e com isso apresentando maior espaçamento entre elas.

Comparando as duas técnicas é possível visualizar a similaridade entre os resultados obtidos nas técnicas de HE (FIG. 15) e Picrosirius (FIG. 16), porém com o Picrosirius se tem uma avaliação melhor dos tipos de fibras e suas proporções.

$\mathrm{Na}$ literatura, encontra-se bem descrito que, utilizando a microscopia eletrônica de varredura, no tendão são encontradas fibras colágenas que não são orientadas somente longitudinalmente, mas também transversalmente e horizontalmente com as fibrilas longitudinais, também cruzando entre si, formando espirais e tranças (Kannus, 2000).

Pelo tendão ter sua estrutura formada por mais de um tipo de orientação no mesmo tecido, observou-se com as colorações de HE e Picrosirius, variações em diferentes graus nas amostras irradiadas, porém os resultados podem não ser conclusivos, pelo tamanho da amostra avaliada. De qualquer maneira, pode-se observar que após o processo de irradiação a integridade das fibras colágenas foi mantida.

Como já é conhecido que a radiação gama pode ter efeitos em vários tecidos e órgãos, uma atenção especial tem sido focada no colágeno e nas proteínas não colágenas. A microscopia tem sido utilizada para detectar tais alterações das fibrilas de colágeno ocasionadas pela radiação gama (Gut e col., 2016).

De acordo com Gut (2016) aloenxertos tendíneos de coelhos irradiados nas doses de 25, 35, 50 e 100 kGy, processados por radiação gama e preservados em ultra freezer, sendo submetido a testes para avaliar mudanças nas 
características destes tecidos, a dose de 35 kGy apresentou melhores resultados, sugerindo assim que o tecido congelado e irradiado preserva as suas características iniciais, não excluindo a aplicação clinica deste material. Levando em consideração estes dados e observando a pouca variação dos resultados obtidos, podemos concluir que as alterações encontradas não afetarão o uso clínico destes tecidos.

Nas análises estatísticas quantitativas das FIG. 17 e FIG.18, foi possível correlacionar os resultados da estatística com os das imagens obtidas com a técnica de picrosirius para as amostras A (FIG.16 amostra A e FIG. 17). O mesmo não foi possível para as amostras B (FIG. 16 amostra B e FIG. 18), isso ocorreu devido à ausência de material em algumas zonas apresentado áreas de coloração preta em diferentes proporções presente nas imagens do método $B$, isso ocasionou um erro, o programa Graph Pad Prism que contabilizou esta área preta como uma cor sendo adicionada a percentagem, mostrando um falso resultado para amostra B, com alterações nos resultados finais.

Para a análise biomecânica das amostras, inicialmente foi realizado um teste de tração (FIG. 19), que serviu de base para os demais testes biomecânicos realizados. Sendo estes: teste de tensão-deformação dividido em duas partes teste monotônico e cíclico. No teste monotônico foi possível obter os valores de força máxima e mínima (Fmax e Fmin, vide Tab. 4, 5, 6 e 7). Nas tabelas previamente citadas foi possível observar os dados de cada corpo de prova (CP) utilizados para os cálculos de Fmax e Fmin, tanto do controle não irradiado, quanto das amostras, de ambos os métodos, irradiadas. Destes dados foram originados os gráficos de tensão deformação (FIG. 20).

Nos testes biomecânicos realizados nas amostras tendíneas foram observadas diferenças extremas entre os métodos utilizados no processamento desses tecidos.

No teste de tração realizado nas amostras controle e irradiadas, foi possível observar uma diferença significativa entre o comportamento das amostras dos dois métodos de processamento.

No teste de tensão máxima $x$ dose (FIG. 21) foi possível observar uma semelhança entre os controles, porém esta semelhança não foi observada nas amostras irradiadas. Nas amostras irradiadas do método A, na dose de 12,5 kGy 
observou-se um valor de tensão máxima superior ao do controle, seguido da dose de 25 kGy que se apresentou bem semelhante ao controle e a dose de 15 kGy um pouco inferior ao controle.

Nas amostras do método $B$ as tensões máximas tiveram um comportamento inferior às do método $A$, apresentando um comportamento nos valores de tensão máxima inversamente proporcional ao valor correspondente às doses aplicadas.

No teste do módulo elástico geral $x$ dose (FIG. 22) para ambos os métodos o controle apresentou mesma taxa de módulo de elástico. O método A seguindo o padrão do teste anterior, a dose de 12,5 kGy apresentou um módulo elástico superior ao controle, nas amostras irradiadas com variação entre elas, sendo o maior valor para a dose de 12,5 kGy, 25 kGy e 15 kGy respectivamente.

No teste do módulo elástico para as três diferentes velocidades de ciclos $\mathrm{x}$ dose (Fig.23), o método A manteve a viscoelasticidade mesmo com o aumento da dose de radiação, o que não foi observado para o método $B$.

Os valores das tensões máximas e módulo elástico dos controles foram semelhantes em ambos os métodos, pois apesar das fibras dos tendões, processados pelo método $\mathrm{B}$, terem sido desalinhadas (como visualizado macroscopicamente e pelo PS-OCT), estas não sofreram ruptura. Porém após a irradiação, foi possível determinar a fragilização destas estruturas no método $B$.

De acordo com Gardner e col. (2013) o tratamento do aloenxerto de tendão com peróxido de hidrogênio no início do processamento de tecidos pode reduzir a contaminação bacteriana, no entanto, os potenciais efeitos colaterais do tratamento com peróxido de hidrogênio incluem a hidrólise do colágeno e isso pode alterar a propriedade mecânica. Com o uso do ultrassom em conjunto com a solução de peróxido de hidrogênio foram notadas alterações na estrutura da amostra e internalização de bolhas. Ocasionadas pelo conjunto do método de processamento causando uma desorganização na orientação das fibras.

Possivelmente a correlação do ultrassom com o peróxido e irradiação, inviabilizaram as amostras, quanto maior a dose de radiação aplicada maior foi a perda da tensão máxima, do modulo elástico e da viscoelasticidade. Como foi possível notar nos gráficos da biomecânica, quanto maior a dose aplicada nas amostras B, maior a variação entre elas. Comparando-se os gráficos da 
biomecânica com as imagens feitas com a coloração de Picrosirius é possível correlacionar a diferença entre as amostras de cada método em relação a tensão, módulo elástico e viscoelasticidade devido a variação do calibre das fibras presentes no tecido de cada amostra após seus processamentos (vide FIG. 16 e FIG. 21, 22 e 23) 


\section{CONCLUSÃO}

- Dos dois processamentos utilizados no preparo das amostras apenas o processamento com álcool e antibiótico se mostrou eficaz para este tipo de tecido.

- Ocorreram algumas alterações na morfologia do tecido pela radiação ionizante, mas a integridade das fibras colágenas foi preservada.

- Nas doses estudadas, o direcionamento das fibras colágenas não foi comprometido nas amostras processadas com álcool e antibiótico.

- Apesar de existir um relaxamento da rede de colágeno, quando os tendões são irradiados com 25 kGy, esta característica não interferiu significativamente nas propriedades biomecânicas dos mesmos.

- Na dose de irradiação de 12,5 kGy observou-se uma tendência de aumento no modulo elástico e na viscoelasticidade do tecido. 


\section{TRABALHOS FUTUROS}

- Aquisição de novas amostras do método B, para realizar novo teste de quantificação das imagens da análise histológica corada com Picrosirius.

- Analisar as causas dos diferentes resultados nos testes viscoelásticos para a dose de 12,5 kGy.

- Estudo para compreender os mecanismos de falha nas amostras processadas pelo método $B$. 


\section{REFERÊNCIAS BIBLIOGRÁFICAS}

1. ALBERTS, B.; BRAY, D.; LEWIS, J.; RAFF, M.; ROBERTS, K.; WATSON, J. D. Biologia Molecular da célula. 5. ed., 2002.

2. ALENCAR, P. G. C.; VIEIRA, I. F. V. Banco de ossos. Rev Bras Ortop., v. 45, n. 6, 2010.

3. ALMEIDA, H. O.; BRANDÃO, M. C.; MORAIS, M. G. R.; REIS, M. A.; SILVEIRA, S. A. Utilização do picro-sirius para corar o Paracoccidioides brasiliensis. Rev Soc Bras Med Trop, v. 21, n.2, p. 59-62. 1988.

4. ANDARAWIS-PURI, N., SEREYSKY, J. B., JEPSEN, K. J., FLATOW, E. L. The relationships between cyclic fatigue loading, changes in initial mechanical properties, and the in vivo temporal mechanical response of the rat patellar tendon. J Biomechan. v. 45(1):59-65, 2012.

5. ANDERSEN M. B; PINGEL, J.; KJAER, M.; LANGBERG $\mathrm{H}$. Interleukin-6: a growth factor stimulating collagen synthesis in human tendon. J Appl Physiol,110, p.1549-1554, 2011.

6. ANDREWS J. M. Determination of minimum inhibitory concentrations. J Antimicrob Chemother., v. 48, p.5-16, 2001.

7. ARIZONO T.; IWAMOTO Y.; OKUYAMA K.; SUGIOKA Y. Ethylene oxide sterilization of bone grafts. Residual gas concentration and fibroblast toxicity. Acta Orthop Scand 1994; 65: 640-642

8. ARNOCZKY S. P.; WARREN R. F.; ASHLOCK M. A.; Replacement of the anterior cruciate ligament using a patellar tendon allograft: an experimental study. J Bone Joint Surg [Am] 1986;68-A:376-85. 
9. BAGNANINCHI, P.O.; YANG, Y.; BONESI, M.; MAFFULLI, G.; PHELAN, C.; MEGLINSKI, I.; EL HAJ, A.; MAFFULLI, N. In-depth imaging and quantification of degenerative changes associated with Achilles ruptured tendons by polarization-sensitive optical coherence tomography. Phys Med Biol., v. 55, n.13, p. 3777-3787, 2010.

10. BARRY, B.; ENOKA, R. The neurobiology of muscle fatigue: 15 years later. Integr. Comp. Biol. v. 47, n. 4, p. 465-473, 2007.

11. BENJAMIN, M.; KAISER, E.; MILZ, S. Structure-function relationships in tendons: a review._J Anat., v. 212. p. 211-228, 2008.

12. BONAFE, J. L.; PIERAGGI, M. T.; ROCHICCIOLI, P. Etude du collagene dermique par la coloration du rouge sirius au cours de maladies congenitales ou acquises du tissu conjonctif._Ann Dermatol Venereol. v. 108: p. 635-640, 1981.

13. BORGES L. F., GUTIERREZ, P.S, MARANA, H. R., TABOGA, S. R. Picrosirius-polarization staining method as an efficient histopathological tool for collagenolysis detection in vesical prolapse lesions. Micron v.38 p. 580583, 2007.

14. BRASIL, Lei o 10211, de 23 de março de 2001. Altera os dispositivos da Lei no 9.434, de 04 de fevereiro de 1997, que "Dispõe sobre a remoção de órgãos e tecidos e partes do corpo humano para fins de transplante e tratamento". D.O.U. - Diário Oficial da União, Poder Executivo, de 23 de março de 2001. Disponível em: http//:www.planalto.gov.br/ccivil03/leis/leis/2001//10211.htm. Acesso em: 1 set. 2016.

15. BRASIL, Lei no 9.434, de 04 de fevereiro de 1997. Dispõe sobre a remoção de órgãos, tecidos e partes do corpo humano para fins de transplante e tratamento e da outras providencias. D.O.U. - Diário Oficial da 
União, Poder Executivo, de 05 de fevereiro de 1997. Disponível em: http//:www.planalto.gov.br/ccivil03/leis/19434.htm. Acesso em: 1 set. 2016.

16. BRASIL, portaria o lei oㅡ 2.600, de 21 de outubro de 2009. Aprova 0 Regulamento Técnico do Sistema Nacional de Transplantes. Disponível em: http://bvsms.gov.br/bvs/saudelegis/gm/2009/prt260021102009.htm. Acesso em: 1 set. 2016.

17. COLEMAN, R. Picrosirius red staining revisited. Acta Histochem., v.113, p. 231-233, 2011.

18. CONSTANTINE, V. S.; MOWRY, R. W. Selective staining of human dermal collagen. II - The use of Picrosirius Red F3BA with polarization microscopy. J Invest Dermatol, v. 50, p. 419-423, 1968.

19. DAHLAN, K. Z. H. M. Radiation Sciences. In: PHILLIPS, G. O.; NATHER, A. (Ed.). The Scientific Basis of Tissue Transplantation. Singapura: World Scientific, 2001.

20. DI GIULIO, C.; DANIELE, F.; TIPTON, C. Angelo Mosso and muscular fatigue: 116 years after the first congress of physiologists. Adv Physiol Educ. v. 30, p. 51- 57, 2006.

21. DROBNY, J.G. Ionizing Radiation and Polymers: Principles, Technology and Applications. $1^{\text {st }}$ ed. Estados Unidos: Elsevier, 2012.

22. DZIEDZIC-GOCLAWSKA, A. The application of ionising radiation to sterilise connective tissue allografts. In: PHILLIPS, G.O. (Ed.). Radiation and Tissue Banking, Singapore: World Scientific, 2000.

23. DZIEDZIC-GOCLAWSKA, A. Aplicacion de la radiacion ionizante para esterilizar aloinjertos de tejido conectivo. In: PHILLIPS, G. O. (Ed). Radiacion y operacion de Banco de Tejidos. Perú: Printing service, 2001. 
24. DZIEDZIC-GOCLAWSKA, A.; KAMINSKI, A.; UHRYNOWSKATYSZKIEWICZ, I.; STACHOWICZ, W. Irradiation as a safety procedure in tissue banking._Cell Tissue Bank. v. 6, p. 201-219, 2005.

25. FANJUL-VÉLEZ, F.; ORTEGA-QUIJANO, N.; ARCE-DIEGO, J. L. Polarimetry group theory analysis in biological tissue phantoms by Mueller coherency matrix. Optics Communications, v. 283, n. 22, p. 4525-4530, 2010.

26. FREEDMAN, B. R; GORDON, J. A; SOSLOWSKY, L. J. The Achilles tendon: fundamental properties and mechanisms governing healing. Muscles, Ligaments Tendons J. v. 4, n. 2, p. 245-255, 2014.

27. GEESINK R. G. Osteoconductive coatings for total joint arthroplasty. Clin Orthop Relat Res; 395: 53-65, 2002.

28. GERE, J. M. Mechanics of materials. $9^{\text {th }}$ ed. Stamford, Conn.; United Kingdom: Cengage Learning, 2009.

29. GLUCK, G. S.; HECKMAN, D. S.; PAREKH, S. G. Tendon Disorders of the Foot and Ankle, Part 3: The Posterior Tibial Tendon. Am J Sports Med., v. 38, n. 10 p. 2133-2144, 2010.

30. GOUK S. S., KOCHERGINSKY, N. M., KOSTETSKI, Y. Y. et al., "Synchrotron radiation-induced formation and reactions of free radicals in human acellular dermal matrix," Radiation Research, vol. 163, n. 5, pp. 535-543, 2005.

31. GRANATO, D, CALADO, V.M.A., \& JARVIS, B. Observations on the use of statistical methods in food science and technology. Food Res. Int., 55:137-149, 2014. 
32. GUT, G.; MAROWSKA, J.; JASTRZEBSKA, A.; OLENDER, E.; KAMIŃSKI, A. Structural mechanical properties of radiation-sterilized human Bone-Tendon-Bone grafts preserved by different methods. Cell Tissue Bank., v. 17, n. 2, p.277-287, 2016.

33. HARNER C. D.; OLSON E.; IRRGANG J.J.; et al. Allograft versus autograft anterior cruciate ligament reconstruction. Clin Orthop 1996; 324:134-44.

34. HAWLEY, J.; REILLY, A. Fatigue revisited. J Sports Sci. v. 15, n. 3, p. 245-246, 1997

35. IAEA. Guidelines for industrial radiation sterilization of disposable medical products. IAEA-TECDOC-539. International Atomic Energy Agency, Vienna, Austria 1990.

36. INTERNATIONAL ATOMIC ENERGY AGENCY. Trends in radiation sterilization of health care products. 3rd ed. Vienna, 2004.

37. ISO 11.137-2:2006. Sterilization of health care products Radiation Part 2: Establishing the sterilization dose. Disponível em: http://www.iso.org. Acesso em 18 de mar. 2017.

38. JOSEPH T. A.; DEFRANCO M. J.; WEIKER G. G. Delayed repair of a pectoralis major tendon rupture with allograft: a case report. $\boldsymbol{J}$ Shoulder Elbow Surg, 12:101-4, 2003.

39. JUNQUEIRA, L. C. U., BIGNOLAS, G.; BRENTANI, R. R. Picrosirius staining plus polarization microscopy, a specific method for collagen detection in tissue sections. Histochem J., v. 11, p. 447-455, 1979. 
40. JUNQUEIRA, L. C. U.; BIGNOLAS, G.; MOURAO, P. A. S.; BONETTI, S. S. Quantitation of collagen-proteoglycan interaction in tissue sections. Connect Tissue. Res, v. 7, p. 91-96, 1980.

41. JUNQUEIRA, L. C. U.; CARNEIRO, J. Histologia básica. 11nd. ed. Rio de Janeiro: Guanabara Koogan, 2008.

42. JUNQUEIRA, L. C.; CARNEIRO, J. Histologia Básica. 12nd. ed. Rio de Janeiro: Guanabara Koogan, 2013.

43. JUNQUEIRA, L.C.U.; COSSERMELLI, W.S. \& BRENTANI, R. Differential staining of collagen type I, II and III by Sirius Red and polarization microscopy. Arch. Histol. Jap. 41: 267-274, 1978.

44. KANNUS, P. Structure of the tendon connective tissue. Scand J Med Sci Sports, 2000; v. 10, p. 312-320, 2000.

45. LIU, X.; TSENG, S. C.; TRIPATHI, R.; HEIFETZ, A.; KRISHNAMURTHY, S.; SHAHRIAR, M. S. White light interferometric detection of unpolarized light for complete Stokesmetric optical coherence tomography. Optics Communications, v. 284, n.14, p. 3497-3503, 2011.

46. MARANGOPOULOS, I. P.; MARTIN, C. J.; HUTCHISON, J. M. S. Measurement of field distributions in ultrasonic cleaning baths: Implications for cleaning efficiency. Phys Med Biol, v. 40, n. 11, p. 1897-1908, 1995.

47. MATTIA, A. L; BARBOSA, M. H.; ROCHA, A. M.; RODRIGUES, M. B.; FREITAS, J. P. A. F.; OLIVEIRA, M. G. Análise das dificuldades no processo de doação de órgãos: uma revisão integrativa da literatura. Bioethikos, v. 4, n. 1, p. 66-74, 2010.

48. MCALLISTER, D. R; JOYCE M. J.; MANN, B. J.; VANGSNESS, C. T. JR. Allograft update: the current status of tissue regulation, procurement, 
processing, and sterilization. Am J Sports Med, v. 35, n. 12. p. 2148-2158, 2007.

49. MONIG, H.J. \& VON VERSEN, R. Standards, Regulatory and Quality Systems, Whithin a Global Context. In: Philips, G. O. (Ed.) Radiation and Tissue Banking, 1st ed., Singapura: World Scientifc Printers, p. 434-454, 2000.

50. MONTES, G. S.; KRISZTAN, R. M.; SHIGIHARA, K. M.; TOKORO, R.; MOURAO, P. A. S.; JUNQUEIRA, L. C. U. Histochemical and morphological characterization of reticular fibers. Histochemistry, v. 65, p. 131-141, 1980.

51. NGUYEN, H.; MORGAN, D. A. F.; FORWOOD, M. R. Sterilization of allograft bone: effects of gamma irradiation on allograft biology and biomechanics. Cell Tissue Bank, v. 8, n. 2, p. 93-105, 2007.

52. NIKOLAEVA S. S.; KONDAKOVA N. V.; KHOROSHKOV IU, A.; DUBINSKAIA, V. A.; KOROLEVA, O. A. Effect of ionizing radiation on the structure of the collagen fibers of human tendons. Radiobiologia, v. 28, p. 483-488, 1988.

53. ORÉFICE R. L.; PEREIRA M. M.; MANSUR H. S. Biomateriais Fundamentos e Aplicações. 1 ed. Guanabara Koogan, 2012.

54. PEDRAZA, J. M. The use of the ionizing radiation thecnique for tissue sterilization. $1^{\text {st }}$ ed. New York, Nova Science,2012.

55. PHILLIPS G. O. Module 5: Processing In: Multimedia distance learning package on tissue banking. $1^{\text {st }}$ Ed., Singapura: IAEA, 1997.

56. PHILLIPS G. O. Radiation technology in surgery and the pharmaceutical industry: an overview of applications. International Atomic Energy Agency Bulletin 36: 19-23, 1994. 
57. PIERAGGI, M. T.; BONAFE, L. Appreciation de l'effet de la Dpenicillamine sur la synthese et le maintien de la structure du collagene, grace a la coloration histologique par le rouge sirius examinee en lumiere polarisee. Ann Pathol. v. 2, p. 155 -157, 1982.

58. POSSSARI, J.F. Esterilização por óxido de etileno. $1^{a}$ ED. São Paulo, SP. látria, 2003.

59. PROLO D. J.; PEDROTTI P. W.; WHITE D. H. Ethylene oxide sterilization of bone, dura mater, and fascia lata for human transplantation. Neurosurgery 6:529-539, 1980.

60. REIFF, R. B. M.; CROCI, A. T.; NETO, R. B.; PEREIRA, C. A. M. Estudo comparativo de propriedades biomecânicas da porção central do tendão calcâneo congelado e a fresco. Acta Ortop Bras, v. 15, n. 1, p. 6-8, 2007.

61. ROBERTSON, A.; NUTTON, R. W.; KEATING, J. F. Current trends in the use of tendon allografts in orthopaedic surgery. J Bone Joint Surg Am, v. 88, p. 988-992, 2006.

62. ROSS, M. H.; CAMISA JR. A.; MICHELIN, A. F. Procedimentos de um banco de ossos e aplicabilidade dos enxertos por ele proporcionados. Acta Ortop Bras, v. 8, n. 3, p. 122-127, 2000.

63. SALDÍAS, I. Á. Guía Para La operación de Bancos de Tejidos. 1nd. ed. Editorial Tecnológica de Costa Rica, 2013.

64. SAMPAIO, S. A. P.; RIVITTI, E. A. Dermatologia. 3nd. ed. São Paulo: Artes Médicas. p. 1-37. 2007. 
65. SCANLAN R. L; GEHL R. S. Peroneal tendon injuries. Clinics in Clin Podiatr Med Surg, v. 19, p. 419- 431, 2002.

66. SCHECHTMAN, H., BADER, D.L. Fatigue damage of human tendons. J. Biomech., v. 35, pp. 347-353, 2002.

67. SETO, A. U.; GATT, C. J.; DUNN, M.G. Sterilization of tendon allografts: a method to improve strength and stability after exposure to 50 kGy gamma radiation. Cell Tissue Bank, v. 14, p. 349-357, 2012.

68. Shane, A. M.; REEVES, C. L.; CAMERON, J. D.; VAZALES, R. Posterior Tibial Tendon Transfer. Clinics in Clin Podiatr Med Surg, v. 33, n. 1, p. 29-40, 2016.

69. SILVA, H. T.; JUNIOR; FELIPE, C. R.; ABBUD - FILHO, M.; GARCIA, V.; MEDINA - PESTANA, J. O. The emerging role of Brazil in clinical trial conduct for transplantation. Am J Transplant. 11(7):1368-75, 2011.

70. SINGH R.; SINGH D.; SINGH A. Radiation sterilization of tissue allografts: A review. World J Radiol. 8:355-69, 2016.

71. SUAREZ, L. S.; RICHMOND, J. C. Overview of procurement, processing, and sterilization of soft tissue allografts for sports medicine. Sports Med Arthrosc, v.15, n. 3, p. 106-113, 2007

72. SWANK, K. R.; BEHN, A. W.; DRAGOO, J. L. The Effect of Donor Age on Structural and Mechanical Properties of Allograft Tendons. Am J Sports Med, v. 43, n. 2, p. 453-459, 2015.

73. SWEAT, F.; PUCHTLER; H. ROSENTHAL, S. L. Sirius red F3BA as a stain for connective tissue. Arch. Pathol. v. 78, p. 69-72, 1964. 
74. TOM J. A.; RODEO S. A. Soft tissue allografts for knee reconstruction in sports medicine. Clin Orthop Relat Res, 402: 135-156, 2002.

75. VANGNESS JR, C.T.; GARCIAI. A.; MILLS, C. R.; KAINER, M. A.; ROBERTS, M. R.; MOORE, T. M. Allograft transplantation in Knee: Tissue Regulation, Procurement, Processing and Sterilization. Am J Sports Med, v. 31, n. 3, p. 474-481, 2003.

76. VOLLESTAD, N. Measurement of human muscle fatigue. J Neurosci Meth. v. 74, p. 219-227, 1997

77. WASCHER D.C.; BECKER JR.; DEXTER J. G.; BLEVINS F.T. Reconstruction of the anterior and posterior cruciate ligaments after knee dislocation: results using fresh-frozen nonirradiated allografts. Am J Sports Med, 27:189-96, 1999.

78. WEATHERFORD, T. W. Staining of collagenous and non-collagen structures with Picrosirius red F3BA. Ala J Med Sci, v. 9: p. 383-388, 1972. 


\section{Anexo}

05/05/2015

Plataforma Brasil

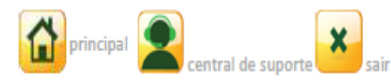

Monica Beatriz Mathor - Pesquisador | V2.21

Você está em: Pesquisador > Gerir Pesquisa

GERIR PESQUISA

Para cadastrar um novo projeto, clique aqui: $\quad$ Nova Submissão Para cadastrar projetos aprovados anteriores à Plataforma Brasil, clique aqui: $\quad$ Projeto anterior

Projetos de Pesquisa:

\begin{tabular}{|c|c|c|c|c|c|c|}
\hline \multicolumn{5}{|l|}{ Título da Pesquisa: } & \multicolumn{2}{|c|}{ Número CAAE: } \\
\hline \multirow[t]{2}{*}{ Pesquisador Responsável: } & & & \multicolumn{2}{|c|}{ Última Modificação: } & \multicolumn{2}{|c|}{ Tipo de Submissäo: } \\
\hline & & & & III & Selecione & $\boldsymbol{V}$ \\
\hline \multicolumn{7}{|l|}{ Palavra-chave: } \\
\hline Situação da Pesquisa & & & & & & 《 \\
\hline Marcar Todas & & & & & & \\
\hline 1 Aguardando para Tramitar & $\checkmark$ & Năo Aprovado na CONEP & \\
\hline$\checkmark$ Aprovado & 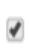 & Näo Aprovado no CEP & \multicolumn{4}{|c|}{ Recurso Submetido ao CEP } \\
\hline$\checkmark$ Em Apreciação Ética & $\checkmark$ & Pendência Documental Emitida pela CONEP & $\checkmark$ & \multicolumn{3}{|c|}{ Recurso Submetido à CONEP } \\
\hline$\checkmark$ Em Edịăa & 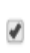 & Pendência Documental Emitida pelo CEP & 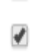 & \multicolumn{3}{|l|}{ Retirado } \\
\hline Em Recepção e Validạ̧ăo Documental & 8 & Pendência Emitida pela CONEP & $\checkmark$ & \multicolumn{3}{|c|}{ Retirado pelo Centro Coordenador } \\
\hline Năo Aprovado - Năo Cabe Recurso & 8 & \multicolumn{5}{|l|}{ Pendência Emitida pelo CEP } \\
\hline
\end{tabular}

$\checkmark$ Năo Aprovado - Nåo Cabe Recurso Buscar Projeto de Pesquisa Lim

\begin{tabular}{|c|c|c|c|c|c|c|c|c|}
\hline \multicolumn{9}{|c|}{ Projeto de Pesquisa: } \\
\hline$T_{i p 0^{*}}$ & Número CAAE * & Título da Pesquisa * & Pesquisador Responsável & Versão * & Ultima Modificaçäo * & Situação & Gestäo da Pes & quisa \\
\hline $\mathrm{P}$ & 00927912.7 .0000 .5421 & $\begin{array}{l}\text { Avaliaçäo de um complexo } \\
\text { papainaciclodextrina inserido em uma } \\
\text { matriz polimérica utilizand(...) }\end{array}$ & Monica Beatriz Mathor & 1 & 02/08/2012 & Aprovado & D & + \\
\hline $\mathrm{P}$ & 10887212.3 .0000 .5421 & $\begin{array}{l}\text { Desenvolvimento e validaçäo de } \\
\text { modelo dermo-epidémico humano } \\
\text { para testes de seguranca e e(...) }\end{array}$ & Monica Beatriz Mathor & 2 & 25/02/2013 & Aprovado & D & + \\
\hline $\mathrm{P}$ & 44688115.0 .0000 .0085 & $\begin{array}{l}\text { AVALIACCÄO BIOMECÁNICA DE } \\
\text { TECIDO TENDINOSO HUMANO } \\
\text { ESTERILIZADO POR RADIACÄO } \\
\text { IONIZANTE }\end{array}$ & Monica Beatriz Mathor & 1 & 05/05/2015 & Aprovado & D & + \\
\hline
\end{tabular}




\section{Apêndices}

Apêndice 1 - Imagens das amostras processadas por PS-OCT

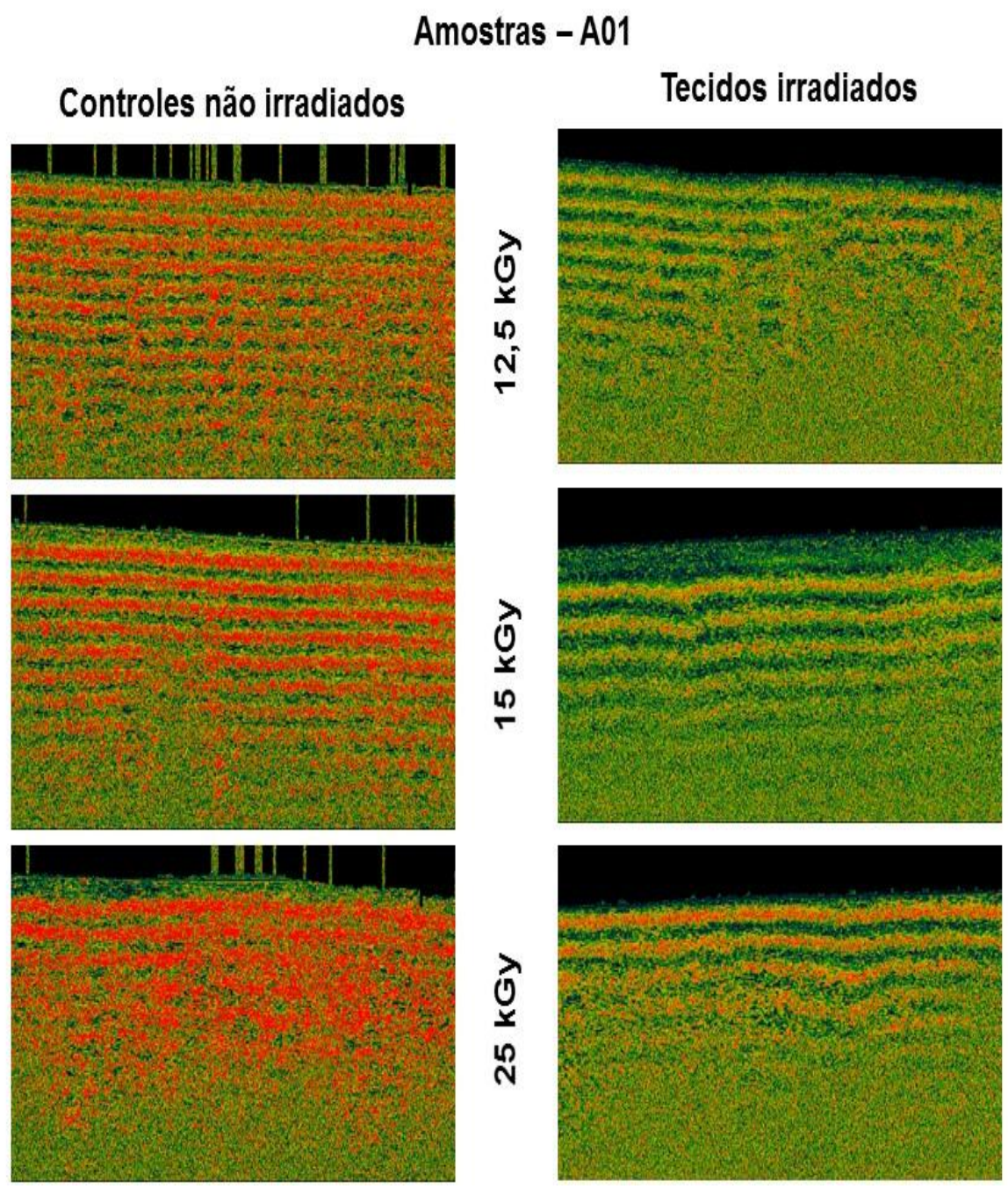




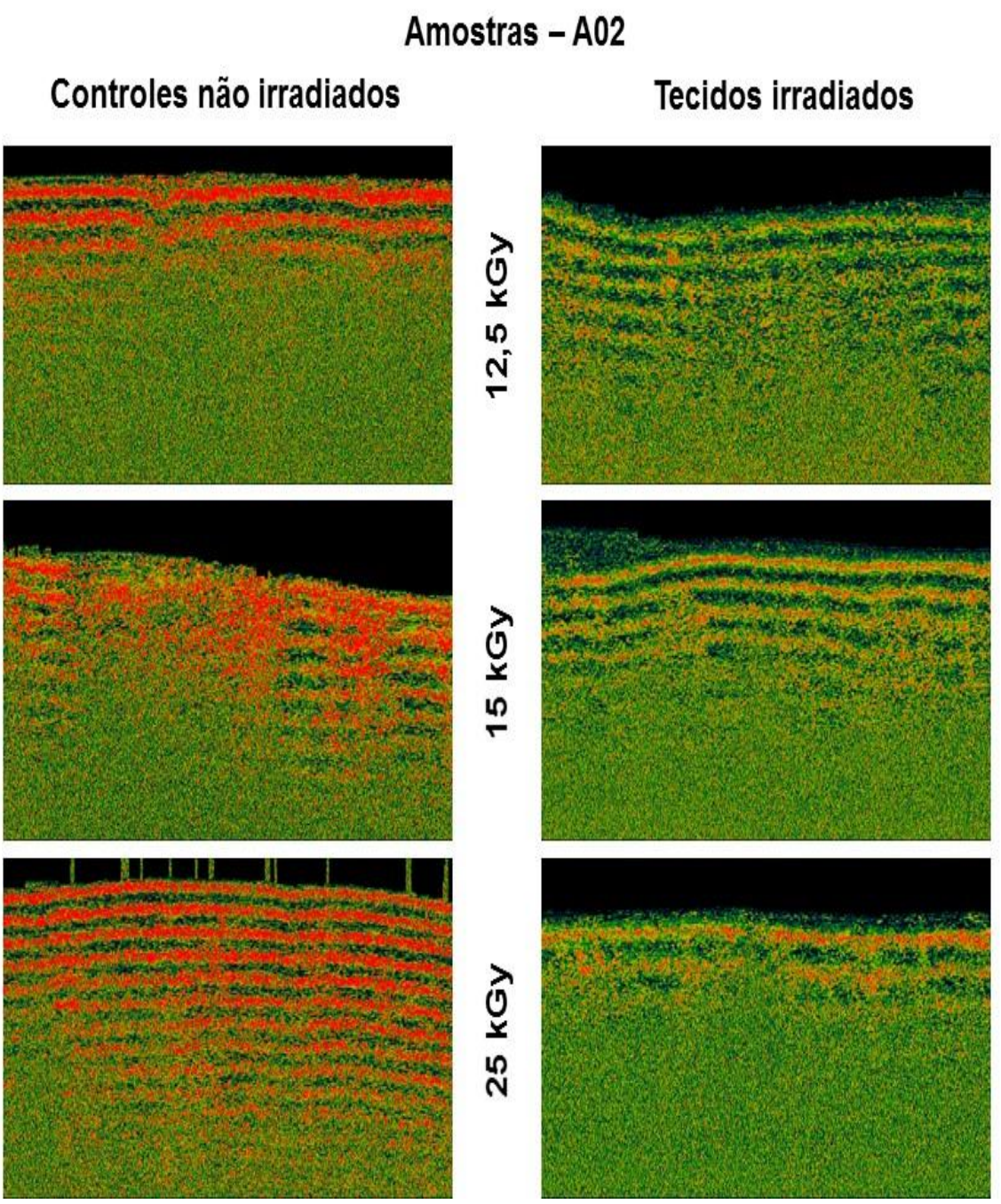




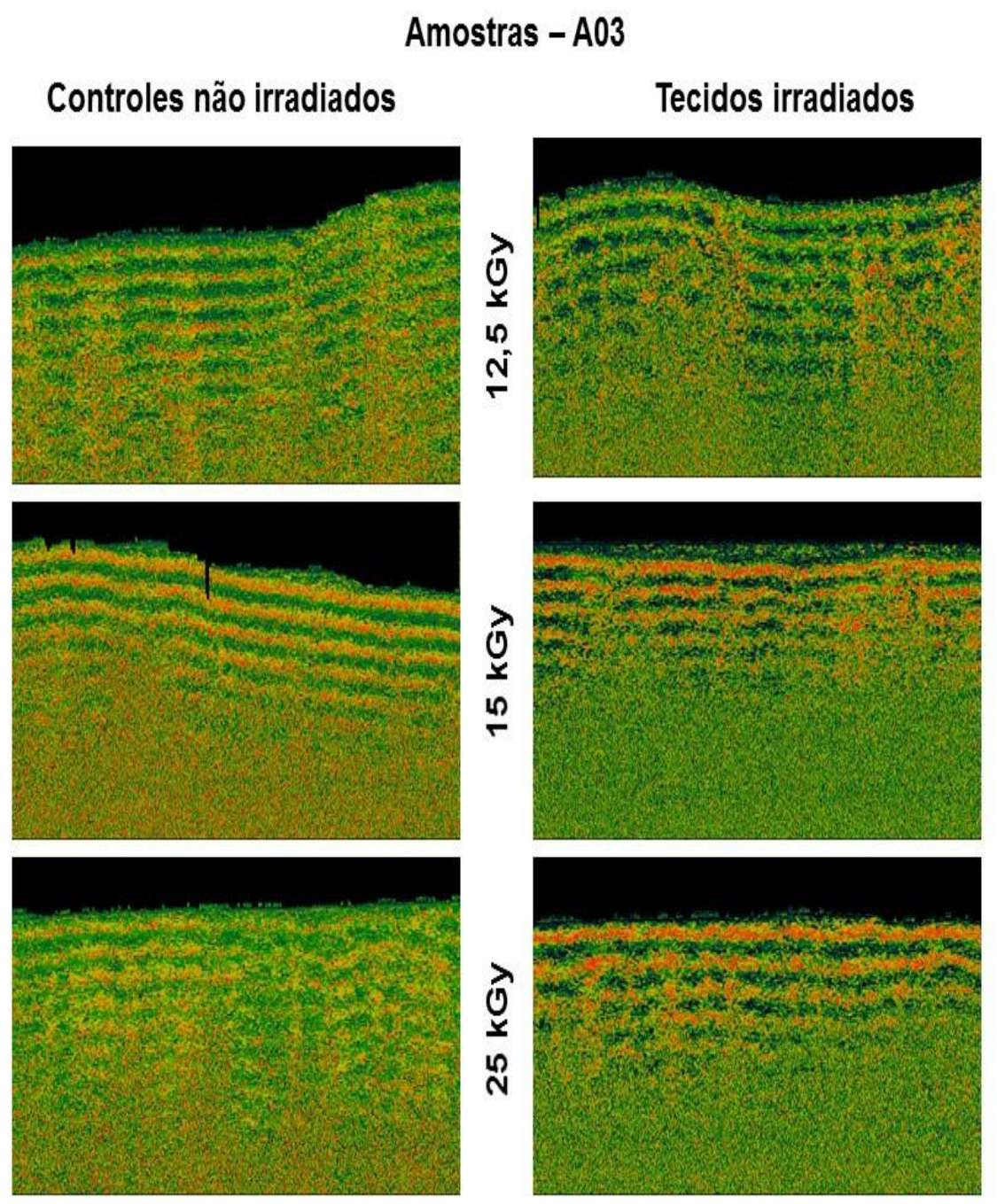




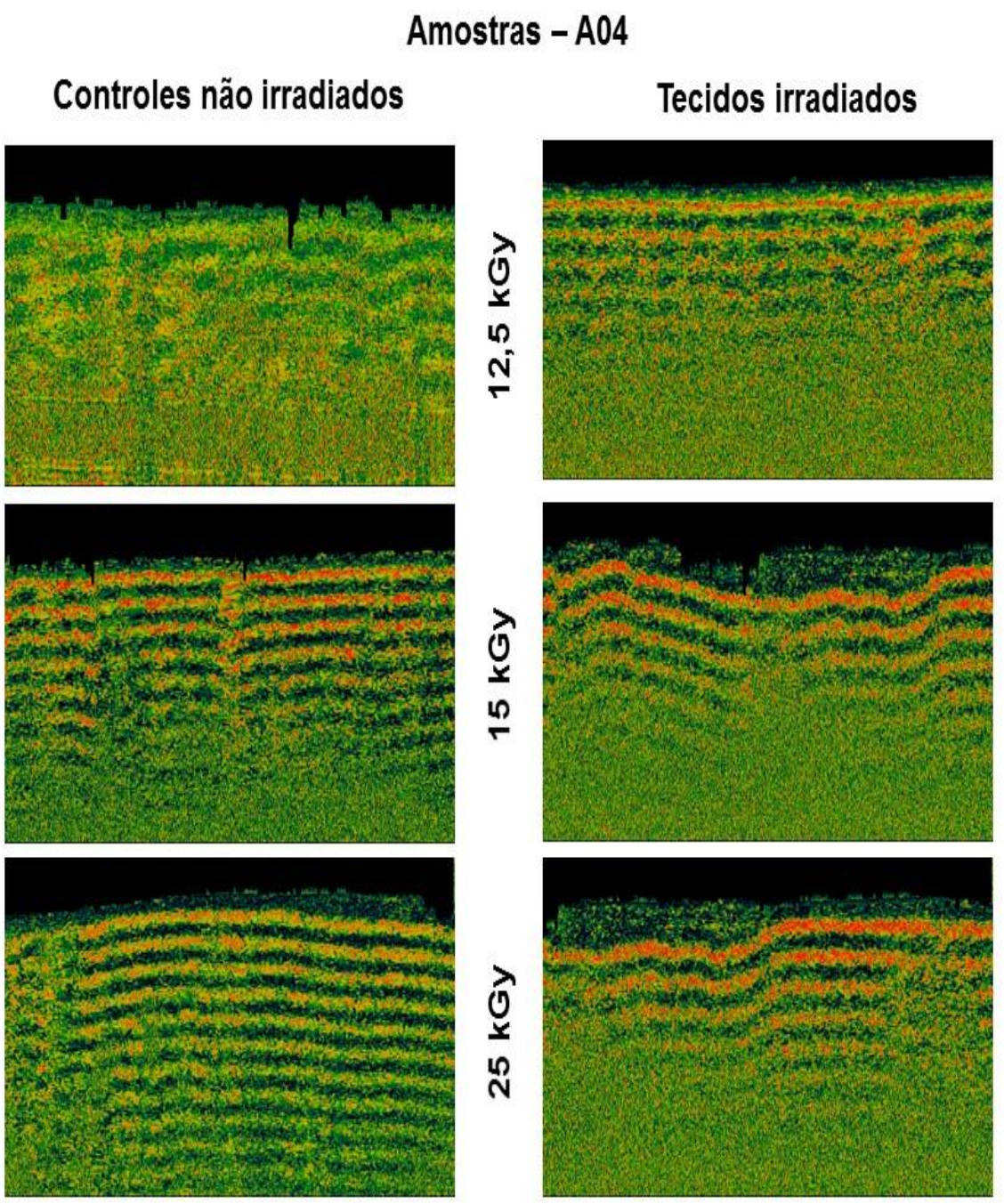




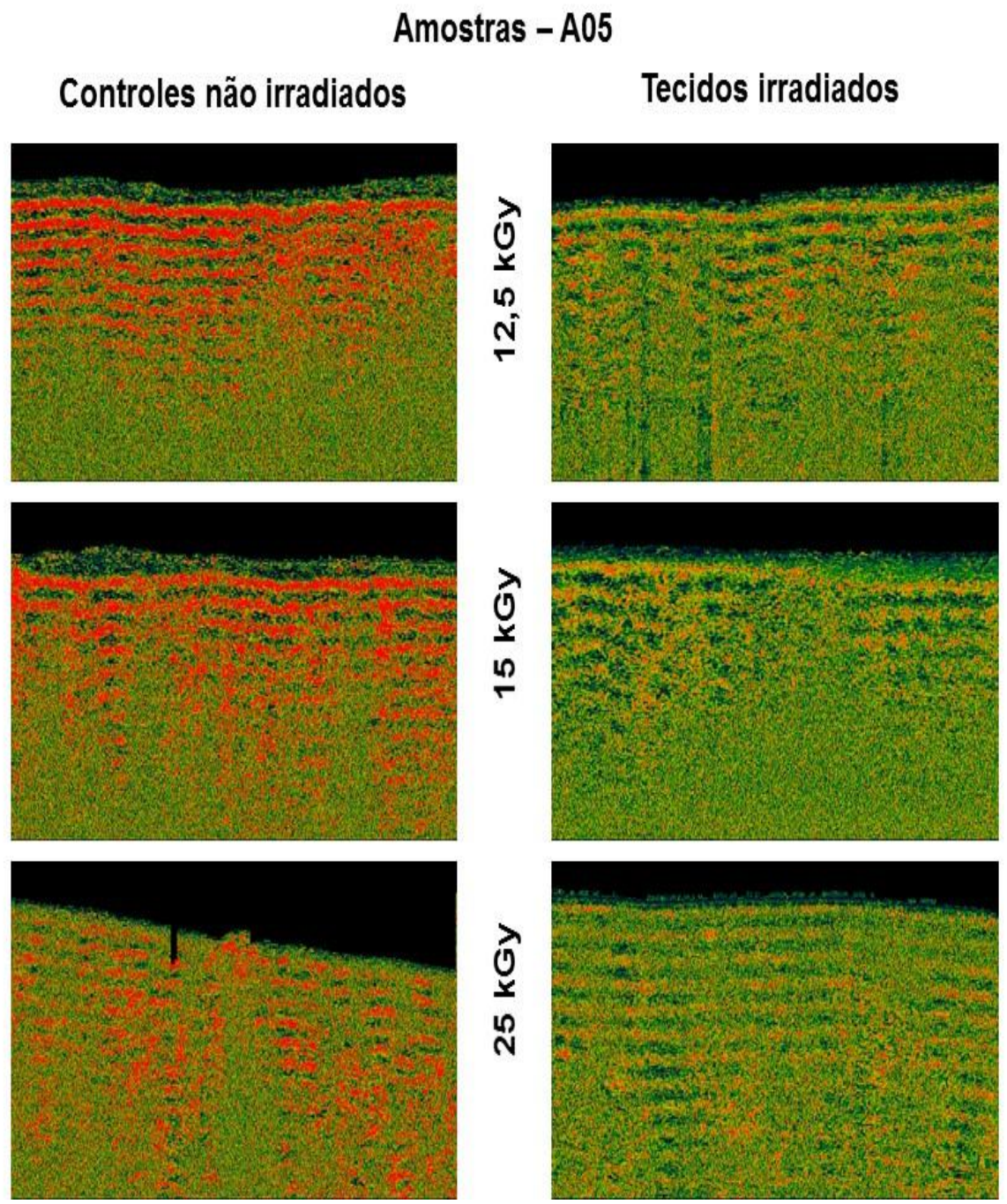




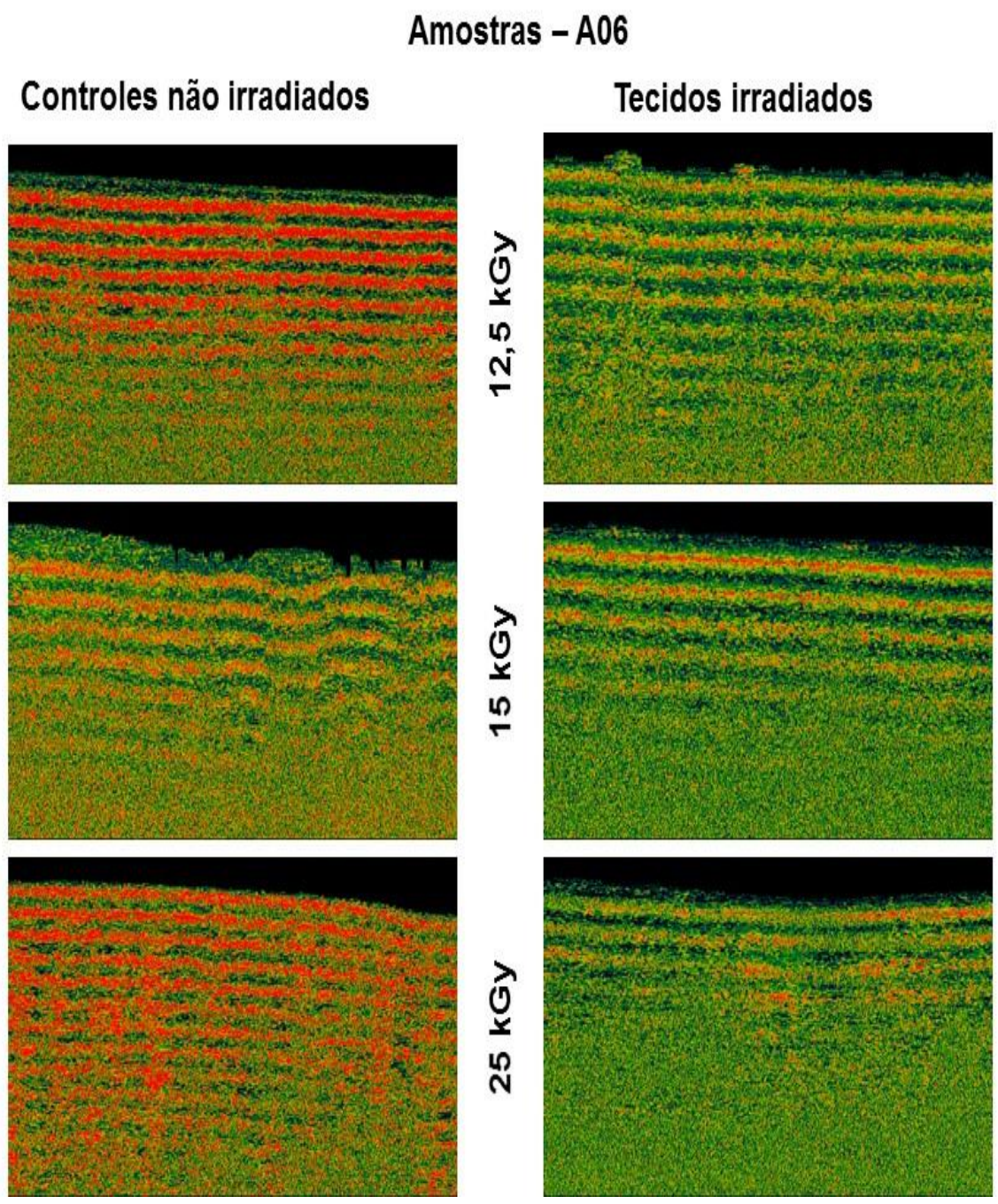




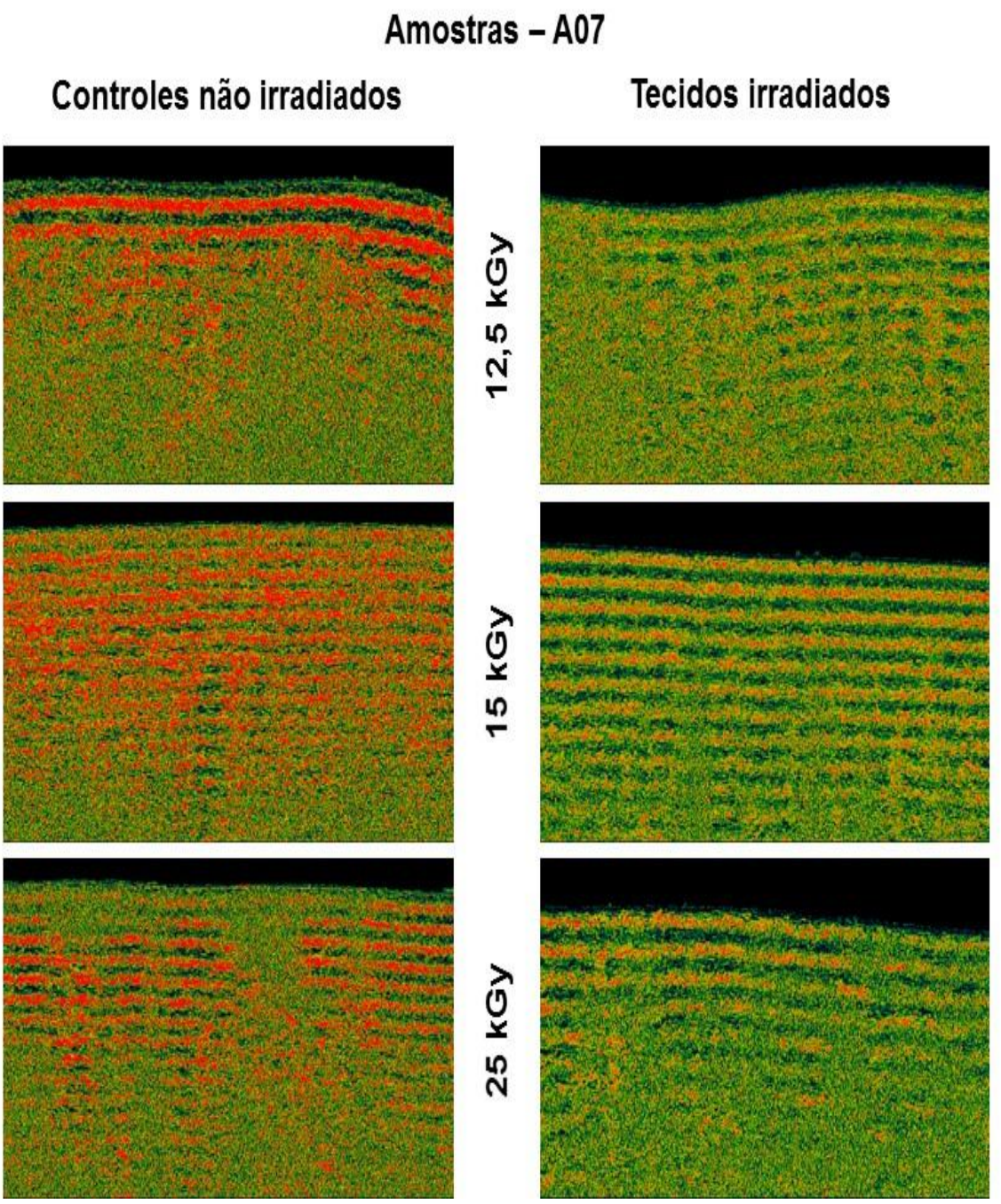




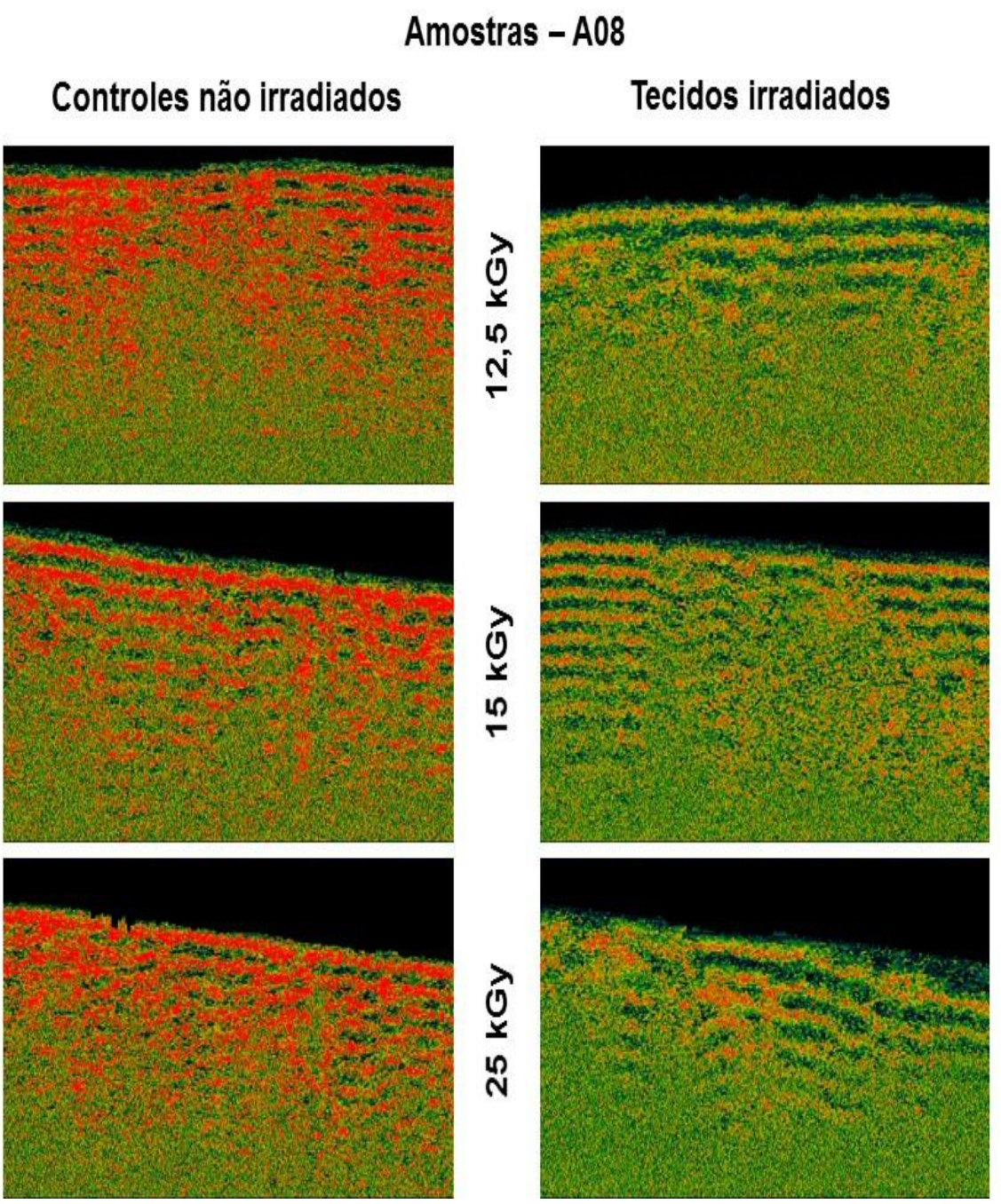

